This document was prepared in conjunction with work accomplished under Contract No. DE-AC09-96SR18500 with the U. S. Department of Energy.

\title{
DISCLAIMER
}

This report was prepared as an account of work sponsored by an agency of the United States Government. Neither the United States Government nor any agency thereof, nor any of their employees, nor any of their contractors, subcontractors or their employees, makes any warranty, express or implied, or assumes any legal liability or responsibility for the accuracy, completeness, or any third party's use or the results of such use of any information, apparatus, product, or process disclosed, or represents that its use would not infringe privately owned rights. Reference herein to any specific commercial product, process, or service by trade name, trademark, manufacturer, or otherwise, does not necessarily constitute or imply its endorsement, recommendation, or favoring by the United States Government or any agency thereof or its contractors or subcontractors. The views and opinions of authors expressed herein do not necessarily state or reflect those of the United States Government or any agency thereof. 
WSRC-TR-2005-00281, REVISION 0

SRNL-RPP-2005-00040, REVISION 0

\section{Hydrogen Generation Rate Scoping Study of DOW Corning Antifoam Agent}

September 2005

SAVANNAH RIVER NATIONAL LABORATORY

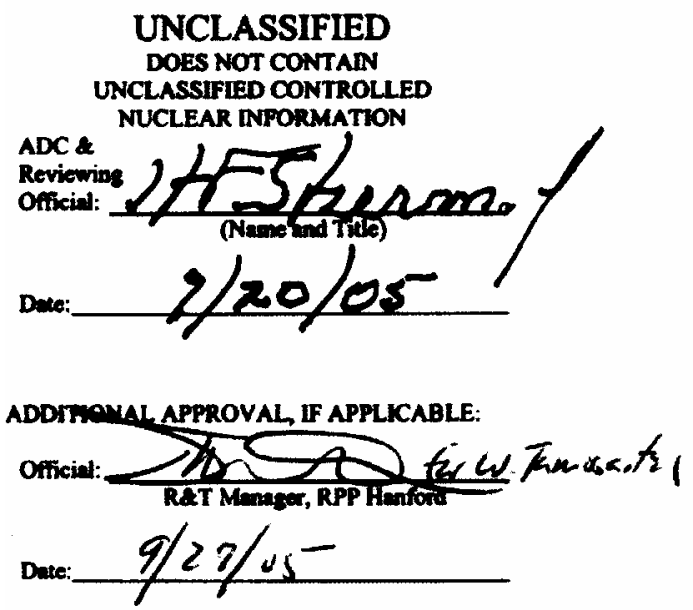

Westinghouse Savannah River Company Savannah River Site Aiken, SC 29808 
WSRC-TR-2005-00281, REVISION 0

SRNL-RPP-2005-00040, REVISION 0

DISCLAIMER

This report was prepared for the United States Department of Energy under Contract No. DE-AC09-96SR18500 and is an account of work performed under that contract. Neither the United States Department of Energy, nor WSRC, nor any of their employees makes any warranty, expressed or implied, or assumes any legal liability or responsibility for accuracy, completeness, or usefulness, of any information, apparatus, or product or process disclosed herein or represents that its use will not infringe privately owned rights. Reference herein to any specific commercial product, process, or service by trade name, trademark, name, manufacturer or otherwise does not necessarily constitute or imply endorsement, recommendation, or favoring of same by Westinghouse Savannah River Company or by the United States Government or any agency thereof. The views and opinions of the authors expressed herein do not necessarily state or reflect those of the United States Government or any agency thereof.

Printed in the United States of America

Prepared For

U.S. Department of Energy 
Key Words:

Antifoam

Hydrogen

Retention:

Permanent

Key WTP R\&T References:

Test Specification

Letter of Instruction CCN 114192

Test Plan WSRC-TR-2005-00144

Implementation Letter CCN 116542

Test Exceptions - None

R\&T Focus Area: Pretreatment and

Vitrification

Test Scoping Statement: S-200

\section{Hydrogen Generation Rate Scoping Study of DOW Corning Antifoam Agent}

\section{Charles L. Crawford, 773-41A, SRNL Cheryl E. Duffey, 773-41A, SRNL Tom L. White, 773-A, SRNL David J. Sherwood, WTP}

September 2005

Westinghouse Savannah River Company Savannah River Site Aiken, SC 29808 
WSRC-TR-2005-00281, REVISION 0

SRNL-RPP-2005-00040, REVISION 0

\section{REVIEWS AND APPROVALS}
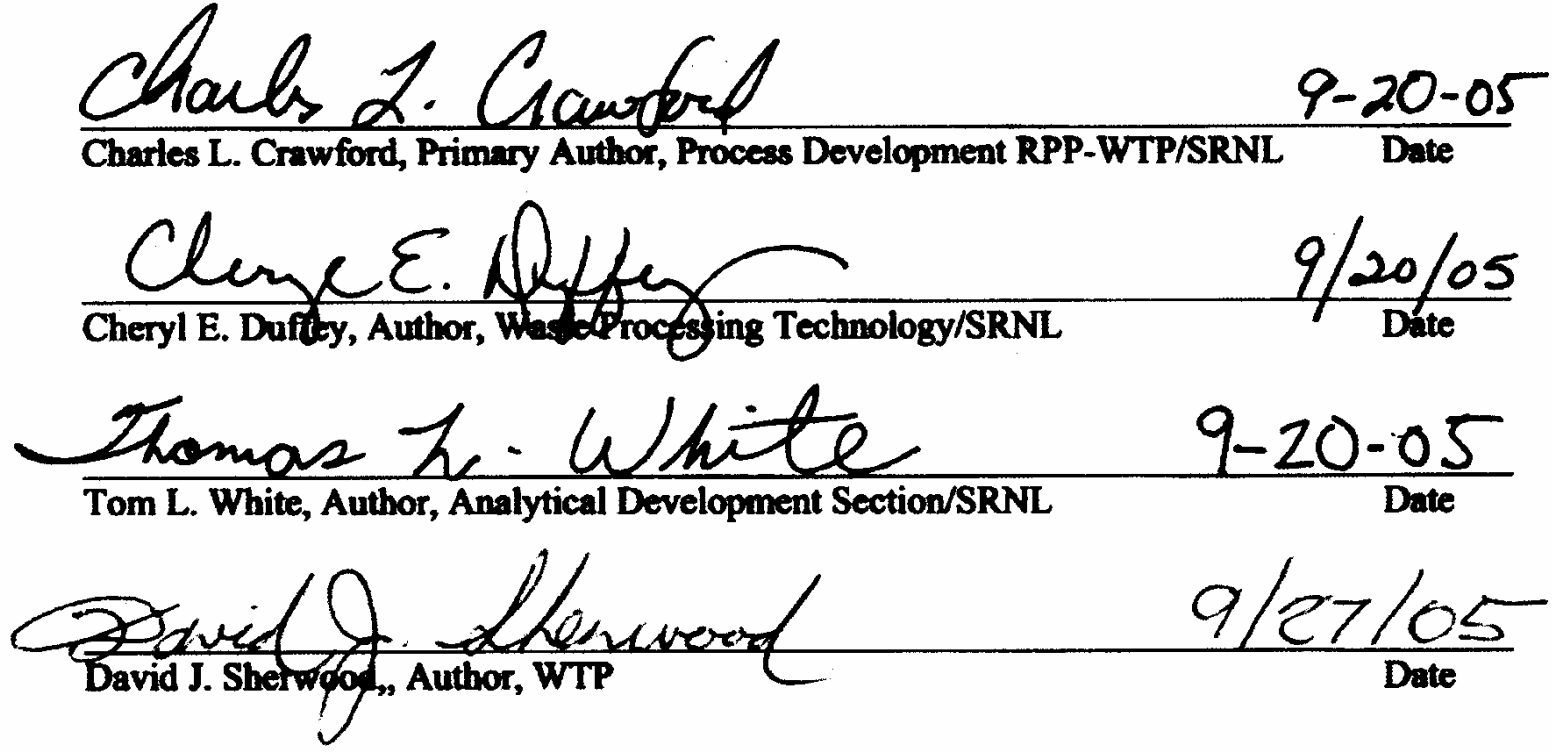
$\frac{\text { Caules }}{\text { Charles A. Nash, Technical Review, Waste Processing Technology/SRNL }} 9-21-05$

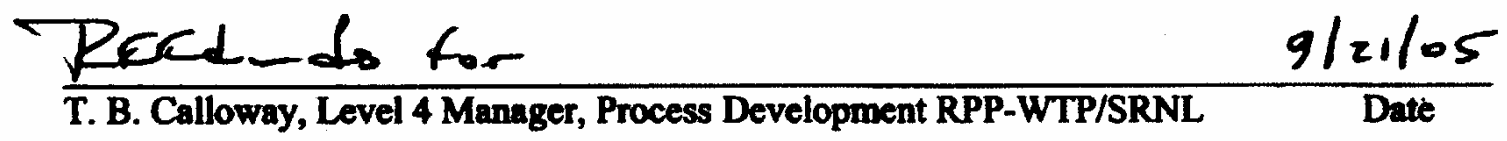

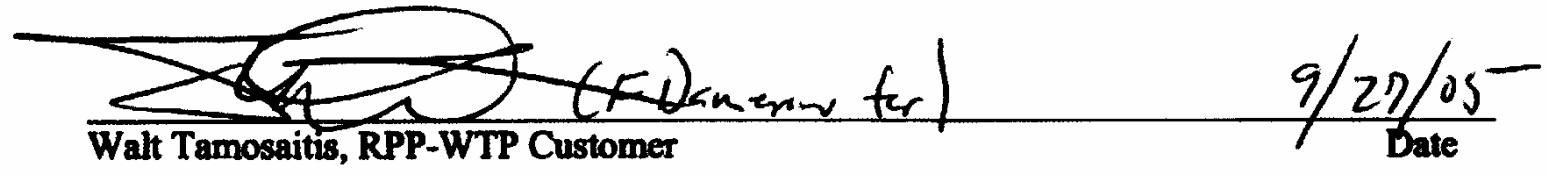


WSRC-TR-2005-00281, REVISION 0

\section{TABLE OF CONTENTS}

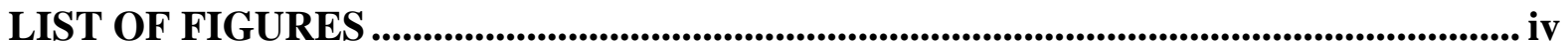

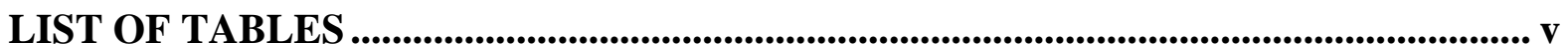

LIST OF ACRONYMS ............................................................................................................... vi

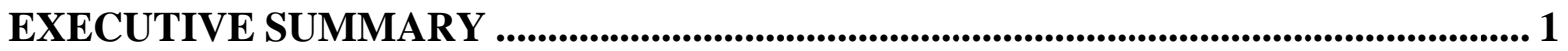

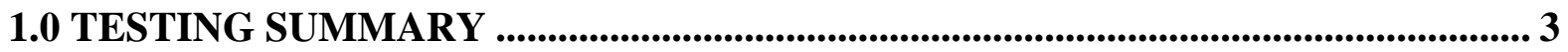

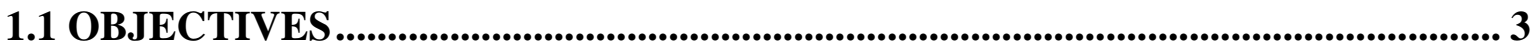

1.2 TEST EXCEPTIONS ....................................................................................................... 4

1.3 RESULTS AND PERFORMANCE AGAINST SUCCESS CRITERIA .................. 4

1.4 QUALITY REQUIREMENTS....................................................................................... 5

1.5 R\&T TEST CONDITIONS ..................................................................................... 5

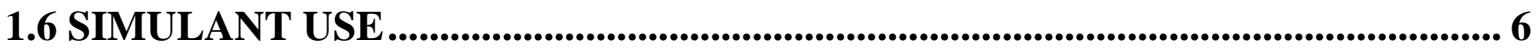

1.7 DISCREPANCIES AND FOLLOW-ON TESTS .......................................................... 7

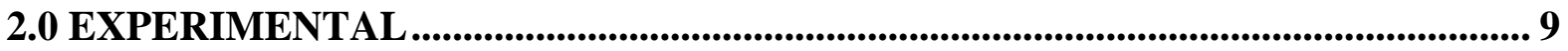

3.0 RESULTS AND DISCUSSION .................................................................................... 13

3.1 SIMULANT PREPARATION ..................................................................... 13

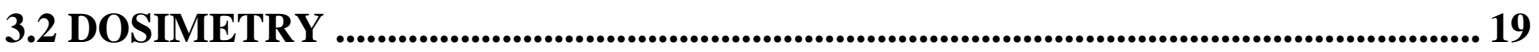

3.3 MEASUREMENT OF TOC CONTENT OF Q2-3183A ANTIFOAM .................... 21

3.4 HYDROGEN MEASUREMENTS VIA MASS SPECTROSCOPY ......................... 22

3.5 INITIAL RADIOLYSIS/THERMOLYSIS TESTING................................................ 23

3.6 REPEAT RADIOLYSIS/THERMOLYSIS TESTING ........................................... 26

3.7 SUMMARY OF DATA AND DISCUSSION ............................................................... 29

3.8 SAVANNAH RIVER SITE EXPERIENCE WITH ANTIFOAM AGENTS ........ 30

4.0 ANTIFOAM DEGRADATION ANALYSES AND RADIOLYTIC

DECOMPOSITION SCHEMES.......................................................................... 32

4.1 ANTIFOAM DEGRADATION ANALYSES ............................................................... 32

4.2 RADIOLYTIC DECOMPOSITION SCHEMES............................................................ 33

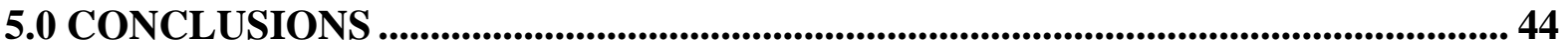

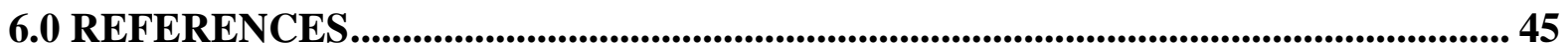

APPENDIX A. SAMPLE CALCULATION OF MEASURED HGR AND MINIMUM

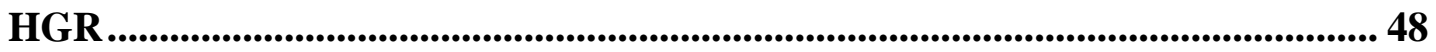

APPENDIX B. SIMULANT RECIPES .......................................................................... 50

APPENDIX C. WTP HGR CORRELATION....................................................................... 58 
WSRC-TR-2005-00281, REVISION 0

SRNL-RPP-2005-00040, REVISION 0

\section{LIST OF FIGURES}

Figure 3-1. Base $0 \mathrm{wt} \%$ TOC simulant (right) and Native $4 \mathrm{wt} \%$ TOC simulant (left) ....... 14

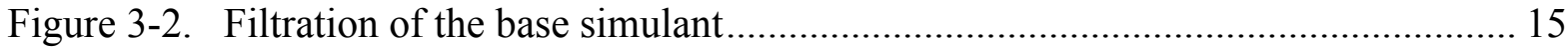

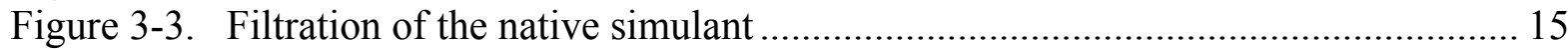

Figure 3-4. AN-107 Envelope C Simulant ……………................................................ 18

Figure 3-5. Fricke Dosimetry Absorbance vs. Time Plot ..................................................... 20

Figure 3-6. Pressure vs. Time Plots for Radiolysis/Thermolysis Initial Testing ................... 24

Figure 3-7. Pressure vs. Time Plots for Radiolysis/Thermolysis Repeat Testing ................ 27

Figure 3-8. Pressure vs. Time Plots for Radiolysis/Thermolysis Repeat Testing Showing

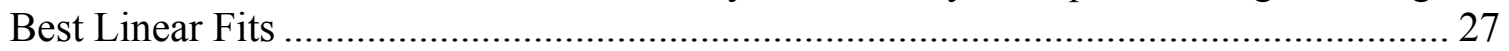

Figure 4-1. Standard Curve for Molecular Weights vs. Retention Time for Polystyrene in

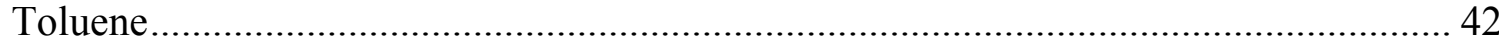

Figure 4-2. Standard Curve for Molecular Weights vs. Retention Time for Polystyrene in

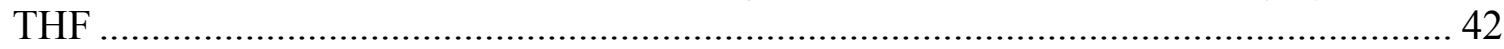

Figure 4-3. PDMS Polymer Direct Radiolytic Decomposition Scheme............................... 43

Figure 4-4. PPG Polymer Direct Radiolytic Decomposition Scheme .................................. 43 
WSRC-TR-2005-00281, REVISION 0

SRNL-RPP-2005-00040, REVISION 0

\section{LIST OF TABLES}

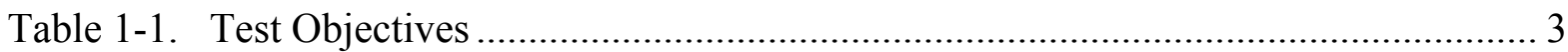

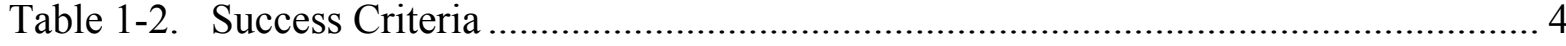

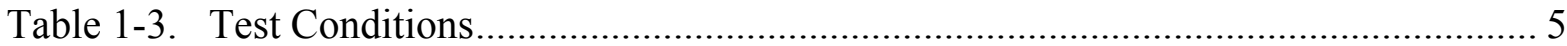

Table 2-1. Dow Corning Q2-3183A Constituents* …………............................................ 9

Table 3-1. Summary Recipes for Base and Native Simulants .............................................. 14

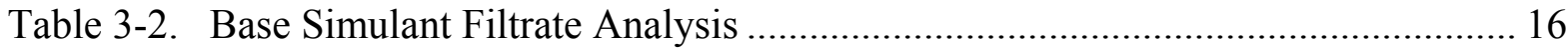

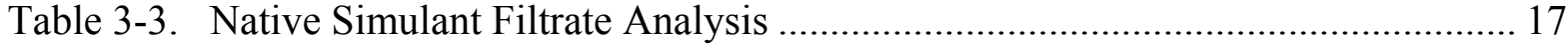

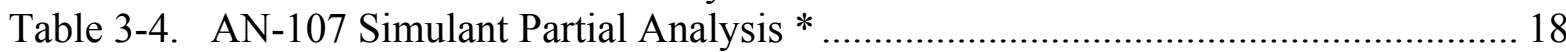

Table 3-5. Ferrous Sulphate 'Fricke Dosimeter' ............................................................... 20

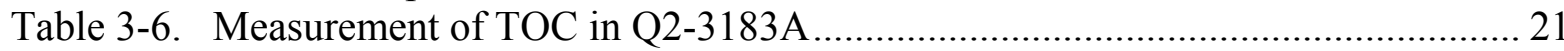

Table 3-7. Mass Spectroscopy Gas Component Measurements in Blank and Standard ...... 22

Table 3-8. Simulant Systems for Radiolysis/Thermolysis Initial Testing ............................. 24

Table 3-9. Hydrogen and HGRs for Radiolysis/Thermolysis Initial Testing ....................... 25

Table 3-10. Simulant Systems for Radiolysis/Thermolysis Repeat Testing.......................... 28

Table 3-11. Hydrogen and HRGs for Radiolysis/Thermolysis Repeat Testing ................... 28

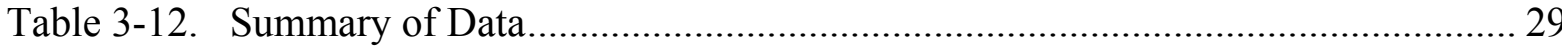

Table 4-1. Summary of Analyses Performed by Dow Corning for SRNL ............................ 35

Table 4-2. Gel Permeation Chromatography with Peak Height ........................................... 36

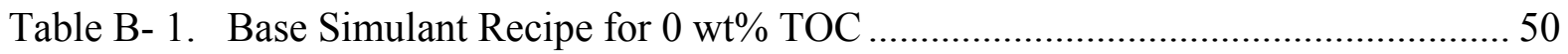

Table B- 2. Batching Recipe for 1000-mL Base Simulant $0 \mathrm{wt} \%$ TOC................................ 52

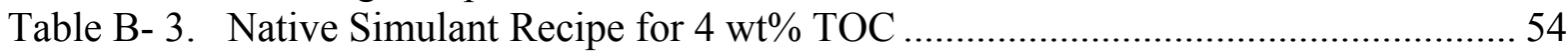

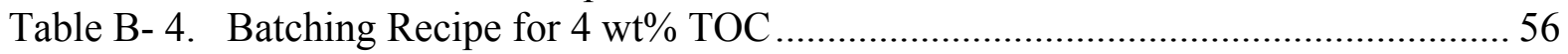




\section{LIST OF ACRONYMS}

$\begin{array}{ll}\text { AFA } & \text { Antifoam Agent } \\ \text { ADS } & \text { Analytical Development Section } \\ \text { DWPF } & \text { Defense Waste Processing Facility } \\ \text { EDL } & \text { Engineering Development Laboratory } \\ \text { GPC } & \text { Gel Permeation Chromatography } \\ \text { HEDTA } & \text { n-(2-Hydroxyethyl)ethylenediaminetriacetic acid } \\ \text { HGR } & \text { Hydrogen Generation Rate } \\ \text { LAW } & \text { Low Activity Waste } \\ \text { MFT } & \text { Melter Feed Tank } \\ \text { MSDS } & \text { Material Safety Data Sheet } \\ \text { NDIR } & \text { Non-dispersive infrared detector } \\ \text { PDMS } & \text { Polydimethylsiloxane } \\ \text { PPG } & \text { Polypropyleneglycol } \\ \text { RPP-WTP } & \text { River Protection Program-Waste Treatment and Immobilization Plant } \\ \text { SME } & \text { Slurry Mix and Evaporator } \\ \text { SRAT } & \text { Sludge Receipt and Adjustment Tank } \\ \text { SRNL } & \text { Savannah River National Laboratory } \\ \text { TOC } & \text { Total Organic Carbon }\end{array}$


WSRC-TR-2005-00281, REVISION 0

SRNL-RPP-2005-00040, REVISION 0

\section{EXECUTIVE SUMMARY}

The antifoam agent DOW Corning Q2-3183A will be added to waste streams in the Hanford River Protection Program-Waste Treatment and Immobilization Plant (RPP-WTP) to prevent foaming. It consists mostly of polydimethylsiloxane (PDMS) and polypropylene glycol (PPG). These and other minor constituents of the antifoam have organic constituents that may participate in radiolytic and chemical reactions that produce hydrogen in Hanford waste. It has been recommended by The WTP R\&T Department recommended personnel to treat the organic compounds of the antifoam like the in a similar manner as other organic compounds that are native to the Hanford waste with respect to hydrogen production. This testing has investigated the radiolytic and thermal production of hydrogen from antifoam added to simulant waste solutions to determine if the organic components of the antifoam produce hydrogen in the same manner as the native organic species in Hanford waste. Antifoam additions for this testing were in the range of 4 to $10 \mathrm{wt} \%$ to ensure adequate hydrogen detection. Test conditions were selected to bound exposures to the antifoam agent in the WTP. These levels are higher than previously recommended values of $350 \mathrm{mg} / \mathrm{L}$ for actual applications in WTP tanks containing air spargers and pulse jet mixers. Limited degradation analyses for the organic components of the antifoam were investigated in this study. A more detailed study involving analyses of antifoam degradation and product formation is in progress at SRNL and results from that study will be reported at a later time.

The total organic carbon (TOC) content of the Q2-3183A antifoam was measured to be $39.7 \pm 4.9 \mathrm{wt} \%$ TOC. This measurement was performed in triplicate with on three different dilutions of the pure antifoam liquid using a TOC combustion analyzer instrument with catalytic oxidation, followed by $\mathrm{CO}_{2}$ quantification using an infrared detector.

Test results from this study indicate that the WTP HGR correlation conservatively bounds hydrogen generation rates (HGRs) from antifoam-containing simulants if the antifoam organic components are treated the same as other native organics. Tests that used the combination of radiolysis and thermolysis conducted on simulants containing antifoam produced measured hydrogen that was bounded by the WTP correlation. These tests used the bounding WTP temperature of $90^{\circ} \mathrm{C}$ and a dose rate of $1.8 \times 10^{5} \mathrm{rad} / \mathrm{hr}$. This dose rate is about ten times higher than the dose rate equivalent calculated for a bounding Hanford sludge slurry composition of $10 \mathrm{Ci} / \mathrm{L}$, or $2 \times 10^{4} \mathrm{rad} / \mathrm{hr}$. Hydrogen was measured using a quadrupole mass spectroscopy instrument. Based on the analyses from the $4 \mathrm{wt} \%$ and $10 \mathrm{wt} \%$ antifoam samples, it is expected that the HGR results are directly proportional to the antifoam concentration added. A native organic-containing simulant that did not contain any added antifoam also produced a measurable radiolytic/thermal hydrogen rates that was in bounded by the WTP correlation. A base simulant with no added organic produced a measurable radiolytic/thermal HGR that was $\sim 2 \mathrm{X}$ higher than the predicted HGR. 
Analysis of antifoam-containing simulants after prolonged irradiation of $52 \mathrm{Mrad}$ and heating (23 days at $90^{\circ} \mathrm{C}$ ) indicates that essentially all of the PDMS and greater than $60 \%$ of the PPG components are degraded, likely to lower molecular weight species. The antifoam components were analyzed by extraction from the salt simulants, followed by gel permeation chromatography (GPC) by personnel at Dow Corning. A more detailed study of the antifoam degradation and product formation from radiolysis and thermolysis is currently in progress at SRNL. That study uses a dose rate of about $2 \times 10^{4} \mathrm{rad} / \mathrm{hr}$ and bounding temperatures of $90^{\circ} \mathrm{C}$. Results from that study will be reported in a future report. 


\subsection{TESTING SUMMARY}

\subsection{OBJECTIVES}

The test objectives from the Implementation Letter (2005) and Letter of Instruction (2005) for this testing are given in Table 1-1. The initial measurements involved determination of the TOC content of the Q2-3183A antifoam. Bounding hydrogen generation rates (HGRs) were initially determined for simulants with and without antifoam by exposure to radiation and elevated temperature.

Table 1-1. Test Objectives

\begin{tabular}{|c|c|l|}
\hline Test Objective & $\begin{array}{c}\text { Objective } \\
\text { Met (Y/N) }\end{array}$ & Discussion \\
\hline $\begin{array}{l}\text { 1. Measure TOC for unit mass of } \\
\text { Q2-3183A Antifoam agent. }\end{array}$ & Yes & $\begin{array}{l}\text { The TOC content of the antifoam was } \\
\text { measured to be 39\% }+/-4.9 \% \text { as } \\
\text { discussed in Section 3.3 of this report. }\end{array}$ \\
\hline $\begin{array}{l}\text { 2. Measure bounding HGR for } \\
\text { irradiated Hanford waste } \\
\text { solutions containing antifoam } \\
\text { agent in place of native } \\
\text { organic compounds. }\end{array}$ & Yes & $\begin{array}{l}\text { Bounding HGRs measured less than } \\
\text { predicted for the systems with } \\
\text { antifoam. Predicted HGRs agreed } \\
\text { better with the measurements by } \\
\text { considering the antifoam to be } \\
\text { immiscible in the simulants. See } \\
\text { Sections 3.5 - 3.7 of this report. }\end{array}$ \\
\hline $\begin{array}{l}\text { 3. Measure the HGR for the } \\
\text { same waste solution without } \\
\text { radiation. }\end{array}$ & No & $\begin{array}{l}\text { Insufficient time to develop } \\
\text { repeatable test method. }\end{array}$ \\
\hline
\end{tabular}




\subsection{TEST EXCEPTIONS}

No Test Exceptions have been issued in connection with this study.

\subsection{RESULTS AND PERFORMANCE AGAINST SUCCESS CRITERIA}

The Success Criteria from the Implementation Letter are given in Table 1-2. Tests were conducted at a maximum of $90{ }^{\circ} \mathrm{C}$, which is the bounding temperature limit of the WTP. Radiation dose was set at high enough so these tests could produce enough hydrogen gas to allow measurement/detection within about one week. Antifoam was added to the simulants at high $(\sim 10 \mathrm{wt} \%)$ and low $(\sim 4 \mathrm{wt} \%)$ levels much higher than recommended addition levels of $350 \mathrm{mg} / \mathrm{L}$ with $70 \mathrm{mg} / \mathrm{L}$ additions every $24 \mathrm{hrs}$. (Baich et al. 2003 and Hassan et al. 2004), to ensure enough TOC from the antifoam was available for measurable hydrogen generation.

Table 1-2. Success Criteria

\begin{tabular}{|c|l|}
\hline List Success Criteria & $\begin{array}{l}\text { Explain How the Tests Did or Did Not } \\
\text { Meet the Success Criteria }\end{array}$ \\
\hline $\begin{array}{l}\text { 1. HGR measurements for simulated Low } \\
\text { Activity Waste (LAW) with DOW } \\
\begin{array}{l}\text { Corning Q2-3183A Antifoam agent } \\
\text { addition exposed to bounding WTP } \\
\text { conditions (radiation and temperature) } \\
\text { is required. }\end{array}\end{array}$ & $\begin{array}{l}\text { Samples tested gave measurable quantities } \\
\text { of hydrogen gas enabling successful } \\
\text { comparison of measured and predicted } \\
\text { HGRs. }\end{array}$ \\
\hline $\begin{array}{l}\text { 2. Provide information on how well the } \\
\text { antifoam agent is represented by the } \\
\text { key variables in the WTP HGR } \\
\begin{array}{l}\text { Correlation: TOC concentration, TOC } \\
\text { reactivity and temperature. }\end{array}\end{array}$ & $\begin{array}{l}\text { Comparison of the measured and the } \\
\text { predicted HGRs indicate that better } \\
\text { agreement is found when the antifoam is } \\
\text { considered as immiscible because treating } \\
\text { the antifoam TOC in the same manner as } \\
\text { native soluble organic species in the WTP } \\
\text { HGR correlation overpredicts the } \\
\text { measured values. }\end{array}$ \\
\hline
\end{tabular}




\subsection{QUALITY REQUIREMENTS}

This work was conducted in accordance with the RPP-WTP QA requirements specified for work conducted by SRNL as identified in DOE IWO M0SRLE60. SRNL has provided matrices to WTP demonstrating compliance of the SRNL QA program with the requirements specified by WTP. The WTP/SRNL Implementation Letter and Task Technical and QA Plan (Burket 2005a) for this task includes the Quality Assurance Requirements matrix. Specific information regarding the compliance of the SRNL QA program with RW-0333P, Revision 10, NQA-1 1989, Part 1, Basic and Supplementary Requirements and NQA-2a 1990, Subpart 2.7 is contained in these matrices. No RW-0333P requirements were invoked for these investigations.

\subsection{R\&T TEST CONDITIONS}

The Letter of Instruction (CCN 114192) and the Implementation Letter (CCN 116542) establish conditions to ensure that results are valid for project needs. Table 1-3 lists those conditions and indicates whether they were followed. It describes any circumstances and their consequences where deviations were required.

Table 1-3. Test Conditions

\begin{tabular}{|c|l|}
\hline List R\&T Test Conditions & Were Test Conditions Followed? \\
\hline $\begin{array}{c}\text { 1. Recipes for three experimental LAW } \\
\text { simulants are: }\end{array}$ & $\begin{array}{l}\text { Yes. Simulant solutions were made with a } \\
\text { base recipe with no organic added and } \\
\text { with a native recipe containing native } \\
\text { organic compounds. Two different levels } \\
\text { of antifoam agent were added to the base } \\
\text { recipe simulant. However, both the base } \\
\text { recipe simulant and the native organic } \\
\text { simulant initially made for this testing } \\
\text { contained visible undissolved solids. } \\
\text { Therefore, these original simulants were } \\
\text { filtered and the filtrate was tested. }\end{array}$ \\
$\begin{array}{c}\text { Biltrate solutions were analyzed to } \\
\text { native organic compounds added. }\end{array}$ \\
$\begin{array}{c}\text { C. Antifoam Recipe }=\text { same as B but } \\
\text { native organic compounds at two concentrations used in the } \\
\text { different concentrations of Low } \\
\text { TOC and High TOC. }\end{array}$ \\
$\begin{array}{l}\text { WTP HGR correlation (e.g., Al, Nitrate, } \\
\text { Nitrite and TOC). }\end{array}$ \\
\hline
\end{tabular}


WSRC-TR-2005-00281, REVISION 0

SRNL-RPP-2005-00040, REVISION 0

\begin{tabular}{|c|c|}
\hline List R\&T Test Conditions & Were Test Conditions Followed? \\
\hline $\begin{array}{l}\text { 2. All simulants will be exposed to two } \\
\text { temperatures of } 90^{\circ} \mathrm{C} \text { (bounding for } \\
\text { WTP) and } 60^{\circ} \mathrm{C} \text {. }\end{array}$ & $\begin{array}{l}\text { Yes/No. Original testing used the } \\
\text { bounding temperature of } 90^{\circ} \mathrm{C} \text {. After } \\
\text { initial data collected at } 90^{\circ} \mathrm{C} \text { was analyzed } \\
\text { testing was decided to be repeated at } 90^{\circ} \mathrm{C} \\
\text { instead of at } 60{ }^{\circ} \mathrm{C} \text {. Therefore no testing } \\
\text { at } 60^{\circ} \mathrm{C} \text { was performed for this task. }\end{array}$ \\
\hline $\begin{array}{l}\text { 3. All simulants will be exposed to } \\
\text { radiation dose high enough to generate } \\
\text { detectable amounts of hydrogen from } \\
\text { exposure lasting about two weeks or } \\
\text { less. }\end{array}$ & $\begin{array}{l}\text { Yes. A dose rate of } 1.8 \mathrm{E} 5 \mathrm{rad} / \mathrm{hr} \text { was used } \\
\text { for this study. All irradiated systems } \\
\text { showed measured hydrogen levels of } \\
\text { about } 1 \text { vol\% in the headspace, about } 100 \\
\text { times higher than the mass spectroscopy } \\
\text { quantifiable limits. }\end{array}$ \\
\hline 4. Cover gas is air. & $\begin{array}{l}\text { Yes. All testing was performed with air as } \\
\text { the cover gas. }\end{array}$ \\
\hline $\begin{array}{l}\text { 5. Detection limits expressed as HGR is } \\
\text { better than } 1 \mathrm{E}-7 \mathrm{~g} \text {-mol/kg-day. }\end{array}$ & $\begin{array}{l}\text { No. Detection limits for hydrogen using } \\
\text { mass spectroscopy were determined to be } \\
\text { about } 100 \text { ppm or } 0.01 \text { vol\%. Substitution } \\
\text { of this value into sample calculations to } \\
\text { determine the measured HGRs for systems } \\
\text { used in this testing (see Appendix A) } \\
\text { indicates a quantifiable detection limit of } \\
\sim 2.9 \mathrm{E}-7 \mathrm{~g}-\mathrm{mol} / \mathrm{kg} / \mathrm{day} \text {. Although this } \\
\text { value is nearly equal to the specified } \\
\text { detection limit of } 1 \mathrm{E}-7 \mathrm{~g}-\mathrm{mol} / \mathrm{kg} / \text { day, it is } \\
\text { not 'better than'. However, it is adequate } \\
\text { to determine that the WTP HGR } \\
\text { correlation bounds measurements obtained } \\
\text { for bounding WTP conditions. }\end{array}$ \\
\hline
\end{tabular}

\subsection{SIMULANT USE}

This testing used simulants both of nominal high salt compositions and a simulant of waste from tank AN-107. Simulant recipes are described in Tables Table 3-1, Table 3-2, Table 3-3, and Table Table 3-4, and by Appendix B. 


\subsection{DISCREPANCIES AND FOLLOW-ON TESTS}

Thermolysis test results were not repeatable with the methodology used. There was not enough time available to develop an alternative method.

A nominal hydrogen yield $\mathrm{G}$-value for direct radiolysis of the antifoam agent of $\mathrm{G}\left(\mathrm{H}_{2}\right)=5 \mathrm{H}_{2}$ molecules/100 eV absorbed dose was used to support this work. This value is consistent with hydrogen yields reported for irradiation of various saturated hydrocarbons in the range of $\mathrm{G}\left(\mathrm{H}_{2}\right)=3.8$ to $5.7 \mathrm{H}_{2}$ molecules/100 eV absorbed dose (Table 9.1 from Spinks and Woods 1990). An experimental measurement of this $\mathrm{G}\left(\mathrm{H}_{2}\right)$ value could verify/confirm that this is the correct value. The test systems used in this study could easily determine the $\mathrm{G}\left(\mathrm{H}_{2}\right)$ values by irradiation of pure antifoam material and subsequent quantitative analysis of the hydrogen gas by mass spectroscopy. 
WSRC-TR-2005-00281, REVISION 0

SRNL-RPP-2005-00040, REVISION 0

This page intentionally left blank. 
WSRC-TR-2005-00281, REVISION 0

SRNL-RPP-2005-00040, REVISION 0

\subsection{EXPERIMENTAL}

Simulant solutions were prepared using reagent-grade chemicals per the specified test conditions as a base recipe (no organic materials) and as a native recipe containing common organics native to the Hanford waste. A third AN-107 LAW simulant (Saito et al. 2001) was also used. The DOW Corning Q2-3183A Antifoam agent (AFA) consists of polydimethylsiloxane (PDMS) and polypropyleneglycol (PPG) and other constituents shown in Table 2-1 from the DOW Corning Material Safety Data Sheet (MSDS).

Table 2-1. Dow Corning Q2-3183A Constituents*

\begin{tabular}{|c|c|c|}
\hline Chemical Name & $\begin{array}{c}\text { Chemical Abstract } \\
\text { System (CAS) \# }\end{array}$ & Percentage Range \\
\hline polydimethylsiloxane & $63148-62-9$ & $30-70 \%$ \\
\hline $\begin{array}{c}\text { Ethylene oxide - propylene } \\
\text { oxide copolymer glycerol } \\
\text { ether }\end{array}$ & $9082-0-2$ & $5-10 \%$ \\
\hline $\begin{array}{c}\text { Polyethylene glycol } \\
\text { octylphenyl ether }\end{array}$ & $9036-19-5$ & $40-70 \%$ \\
\hline Polypropylene glycol & $25322-69-4$ & $3-7 \%$ \\
\hline Treated Amorphous Silica & - & $1-10 \%$ \\
\hline Treated silica & - & 5 \\
\hline
\end{tabular}

*This material is a proprietary product from Dow Corning and thus the exact amounts of the various constituents are not specified and the nominal percentage ranges of these components are given in the MSDS. 
WSRC-TR-2005-00281, REVISION 0

SRNL-RPP-2005-00040, REVISION 0

Total organic carbon was measured in the neat Q2-3183A antifoam with an OI ANALYTICAL 1020 High Temperature Total Carbon Analyzer (ADS Procedure ADS2255). The OI ANALYTICAL 1020 autosampler features a vertical quartz combustion tube packed with supported platinum catalyst, which receives a continuous flow of oxygen at 200 $\mathrm{cc} /$ minute. The furnace is normally maintained at $680^{\circ} \mathrm{C}$. Samples are introduced into the combustion tube via a fixed volume sampling loop. Through catalytic oxidation the sample is completely oxidized to $\mathrm{CO}_{2}$ and $\mathrm{H}_{2} \mathrm{O}$. The gas flow sweeps the $\mathrm{CO}_{2}$-containing steam out of the combustion tube, through a condenser, and into a gas/liquid separator to trap most of the $\mathrm{H}_{2} \mathrm{O}$. Final $\mathrm{H}_{2} \mathrm{O}$ removal is accomplished by a Nafion membrane dehumidifier with a countercurrent flow of dry oxygen. The dried $\mathrm{CO}_{2}$-containing gas is then passed through a metallic copper halogen scrubber and to a $\mathrm{CO}_{2}$-specific non-dispersive infrared detector (NDIR) for peak quantification. Calibration accuracy is verified before and after analysis at 100 ppm with a standard and recalibration is required if the response is outside of acceptance criteria (nominally 5\%). Deionized water is also checked as a blank and the TOC content is verified to be less than $5 \mathrm{ppm}$. The OI ANALYTICAL system has dynamic range between 5 ppm and 50,000 ppm carbon with a precision of $\pm 15 \%$ or $5 \mathrm{ppm}$, whichever is greater.

The radiolysis and thermolysis test setup for this study used stainless steel vessels (nominally $7 / 16$ " ID x 7.5" length, or 20 cc volume) contained in an aluminum block. Stainless steel vessels were constructed out of pipe stock cut and welded for the bottom seal. Swage connections were put on the vessels and the vessels were all initially pressure and leaked tested to 300 psig by the SRNL Engineering Development Laboratory (EDL). The aluminum block was direct-contact heated using thermal heat wrapping (Thermolyne model BWH01020, 120V, 314 watt, 1 inch wide heavy insulated 'Samox' type). The heat-wrapped aluminum block containing the test vessels was wrapped with refractory insulating material. The power supply for the heat wrap used an $\mathrm{I}^{2} \mathrm{R}$ ThermoWatch Model L14-1800 temperature controller. The temperature controller was redundantly controlled by a backup $\mathrm{I}^{2} \mathrm{R}$ ThermoWatch Model TOW-VOVC overtemperature protection device. Both the temperature controller and the backup overtemperature unit used calibrated K-type thermocouples for temperature measurements. 
The aluminum block containing the sample vessels was placed in a J. L. Shepherd Model 484 Cobalt-60 Gamma Irradiation device (chamber size is 10" width x 10" height x 40" length) and exposed to a dose rate of $1.8 \mathrm{E} 05 \mathrm{rad} / \mathrm{hr}$. The dose rate was measured by chemical Fricke dosimeter (Spinks and Woods 1990). The Fricke (ferrous sulphate) dosimeter involves the radiation-induced oxidation of ferrous ion $\left(\mathrm{Fe}^{2+}\right)$ to ferric ion $\left(\mathrm{Fe}^{3+}\right)$ at low $\mathrm{pH}$ in the presence of oxygen.

Sample vessels were connected to pressure transmitters via $\sim 8 \mathrm{ft}$ of steel capillary tubing (nominally $1 / 32$ " ID x 8 ' L, or $\sim 5$ cc volume). The pressure transmitters (Rosemount Model 1144 ) were calibrated by the EDL over the range of 0 to 25 psig prior to testing. These pressure transmitters have nominal specifications of $0.5 \%$ accuracy of calibrated span and $0.5 \%$ stability of upper range limit for 6 months. The Rosemount pressure transmitters are variable capacitance sensors that allow direct electronic sensing of gage pressure. The capacitance between the sensing diaphragm and the capacitor plate is electronically converted to a two-wire, 4-20 mA de signal.

Filtrates from the simulants were initially weighed out into the steel vessels, followed by aqueous antifoam agent addition onto the top surface of the simulant. The vessels were connected to the capillary tubing via swage lock connectors. No attempts were made to mix the antifoam solution into the simulant solution (i.e., no stirring or agitation) before the systems were sealed. The vessel/capillary tubing connections were then leak-checked by pressurizing the vessel/capillary tubing system with $\sim 50 \mathrm{psi}$ compressed air. The system was sealed and the vessel/capillary connection interface was submerged under water. Any air bubbles observed were indication that the vessel/ capillary connection needed further tightening. All systems were checked until no visible air bubbles were observed from the submerged vessels. After this coarse leak-check of the vessel/capillary tubing interface was performed on each system, the vessel/capillary tubing was then connected to the pressure transmitter. As a final leak check of the total system, each system was then pressurized (to $15-20 \mathrm{psig}$ ) with air from a plastic syringe and sealed. These sealed and pressurized systems were monitored for several hours to monitor for any pressure losses. The sealed systems typically maintained less than 0.01 psig pressure loss during this final leak check.

After leak checks were completed, the systems were opened/equilibrated to atmosphere and resealed (valve closed) with ambient air as the cover gas. Total head-space system volumes were determined after testing by introducing small amounts $(10 \mathrm{cc})$ of air into the systems with a syringe and measuring the resulting pressure increases. These measurements indicated that each head-space volume was $\sim 17 \mathrm{cc}$ when the systems were loaded with test solutions. This head-space volume consisted of the unfilled portion of the test vessel $(20 \mathrm{cc}$ total vessel volume minus about $15 \mathrm{cc}$ of solution), the approximate $5 \mathrm{cc}$ contained in the 8 ' capillary tubing, and other associated volume for swage connections and pressure transmitter connections. 
Samples were heated to $90^{\circ} \mathrm{C}$ in the irradiation device. Constant recording of the pressures and temperatures was performed using a computer and 'LabVIEW' software. When testing was complete, the radiation source was removed and the systems were allowed to cool to ambient temperature. Pre-evacuated (10 mTorr) steel 25-cc gas sampling bulbs fitted with gas-tight valves were then connected to the head-space of each system. The pressurized gases contained in the test system headspace were then expanded into the pre-evacuated gas sample bulb.

The gas sample bulbs were sealed and removed from the system, then transferred at subatmospheric pressure to the vacuum-evacuated manifold of a quadrupole mass spectrometry instrument for gas analysis. A Scotty Specialty Gas standard gas (Cat\# 22561, Lot\# 422208B, Mfg./Exp. date 11/19/04 - 11/19/06) containing 1 vol\% each of carbon dioxide, carbon monoxide, hydrogen, methane and oxygen in 95 vol\% Nitrogen was used to calibrate the mass spectrometer. Appendix A shows a sample calculation to determine the minimum quantifiable HGR for the system. 
WSRC-TR-2005-00281, REVISION 0

SRNL-RPP-2005-00040, REVISION 0

\subsection{RESULTS AND DISCUSSION}

\subsection{SIMULANT PREPARATION}

Simulant solutions used in this study were prepared for the test conditions as a base recipe without organic materials and as a native recipe containing common native organics in the Hanford waste (Implementation Letter 2005). Table 3-1 shows summary recipes for the simulants and Appendix B gives the as-batched composition of these two simulants.

Simulant preparation resulted in a heterogeneous matrix for both recipes. The two simulants thus required filtration to separate an aqueous phase for testing. Figure 3-1 shows the two simulants as batched. The base simulant had significant settled white solids and the native simulant had a very cloudy appearance indicating suspended solids throughout the matrix. Figure 3-2 (base recipe) and Figure 3-3 (native organics recipe) show the filtrations for each simulant.

Table 3-2 shows the resulting base simulant filtrate composition that ADS determined. The last column of Table 3-2 showing average measurement values divided by the original batch target shows that the aluminum and nitrate/nitrite ions for the filtrate were less than targeted but the sodium was in good agreement with the batch target. Certain trace metal compounds were added to the simulant at nominally $5 \mathrm{mg} / \mathrm{L}$. Only chromium was detectable in the filtrate. Table 3-3 shows filtrate analysis for the native simulant filtrate. The last column of Table 3-3 showing average measurement values divided by the original batch target shows that the aluminum was closer to target than the base simulant, but the nitrate/nitrite ions were less than targeted by about the same amount as the base simulant and the sodium was in good agreement again. Analysis of the native organic species (HEDTA and glycolate) showed less than $50 \%$ of target and the TOC analyses indicated overall TOC was only $31 \%$ of target.

Several of the trace metal elements were detectable in the native simulant filtrate $(\mathrm{Cr}, \mathrm{Cu}, \mathrm{Fe}$, $\mathrm{Zn})$.

The AN-107 LAW Envelope C simulant is a complex mixture derived from cross-flow filtration testing at SRNL. Table 3-4 shows a partial composition of this simulant and Figure 3-4 shows a picture of it.

As described in the Experimental Section, all antifoam additions for this study were made by adding weighed amounts of aqueous antifoam solution onto the top surface of the simulants with no mixing or agitation. Visual observation of pre and post tested samples indicated that antifoam material was visible on the top surface of the simulants, i.e., the antifoam solution was not completely miscible in the caustic simulants. It has also been previously observed that the Q2-3183A antifoam forms immiscible droplets on the surface of caustic simulants (see for example Photograph 3-1 from Section 3 and Figures 14, 15 and 31 from Appendix B in (Baich 2003)). 
Table 3-1. Summary Recipes for Base and Native Simulants

\begin{tabular}{|c|c|c|c|}
\hline Constituent & Concentration & $\begin{array}{c}\text { Contained in } \\
\text { Base Simulant } \\
\quad(\text { yes } / \text { no })\end{array}$ & $\begin{array}{c}\text { Contained in } \\
\text { Native Simulant } \\
\text { (yes/no) }\end{array}$ \\
\hline $\mathrm{Al}$ & $1 \mathrm{M}$ & $\mathrm{Y}$ & Y \\
\hline $\mathrm{Na}$ & As required & $\mathrm{Y}$ & $\mathrm{Y}$ \\
\hline $\mathrm{NO}_{2}^{-}$ & $3 \mathrm{M}$ & Y & $\mathrm{Y}$ \\
\hline $\mathrm{NO}_{3}^{-}$ & $3 \mathrm{M}$ & $\mathrm{Y}$ & Y \\
\hline $\mathrm{OH}^{-}$ & $\mathrm{Ph} \sim 13$ & $\mathrm{Y}$ & $\mathrm{Y}$ \\
\hline $\begin{array}{c}\text { Organic } \\
\text { Compounds }\end{array}$ & - & - & - \\
\hline $\begin{array}{l}\text { Glycolic Acid } \\
\text { (native) }\end{array}$ & $3 \mathrm{wt} \%$ TOC & $\mathrm{N}$ & $\mathrm{Y}$ \\
\hline HEDTA (native) & $1 \mathrm{wt} \% \mathrm{TOC}$ & $\mathrm{N}$ & $\mathrm{Y}$ \\
\hline Antifoam & $\begin{array}{c}4 \mathrm{wt} \% \mathrm{TOC} \\
\text { (high) or } 1 \mathrm{wt} \% \\
\text { TOC (low) }\end{array}$ & $\mathrm{Y} / \mathrm{N}^{*}$ & $\mathrm{~N}$ \\
\hline
\end{tabular}

* Base simulant tested with and without antifoam addition.

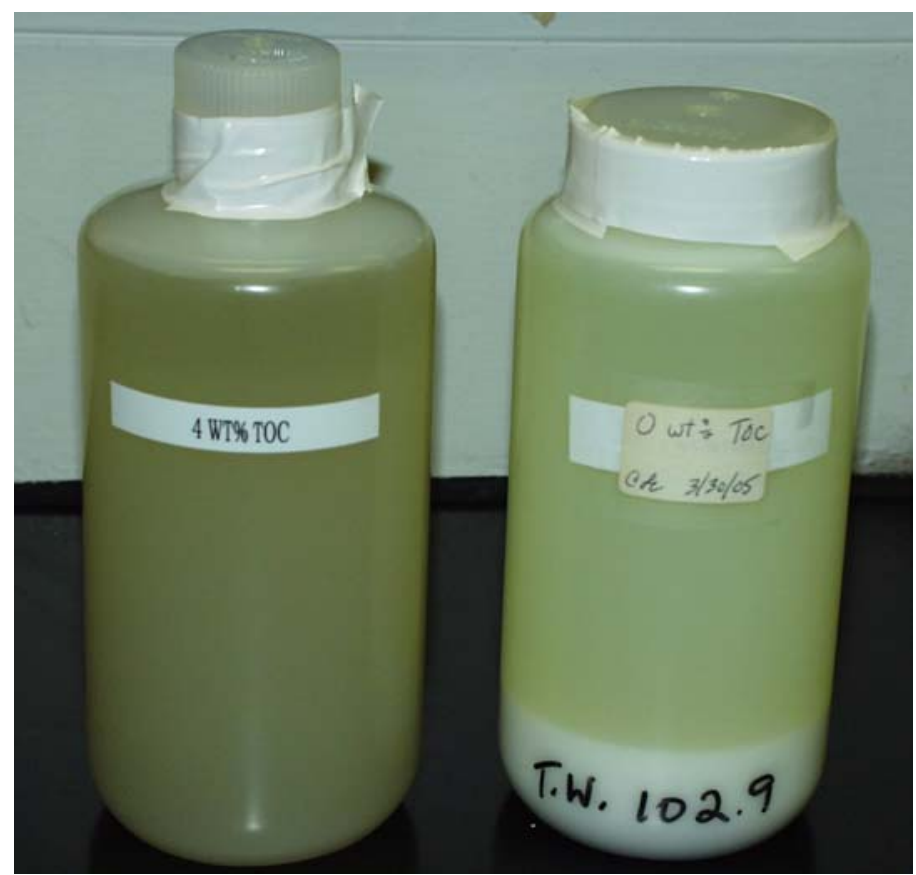

Figure 3-1. Base 0 wt \% TOC simulant (right) and Native 4 wt \% TOC simulant (left) 
WSRC-TR-2005-00281, REVISION 0

SRNL-RPP-2005-00040, REVISION 0

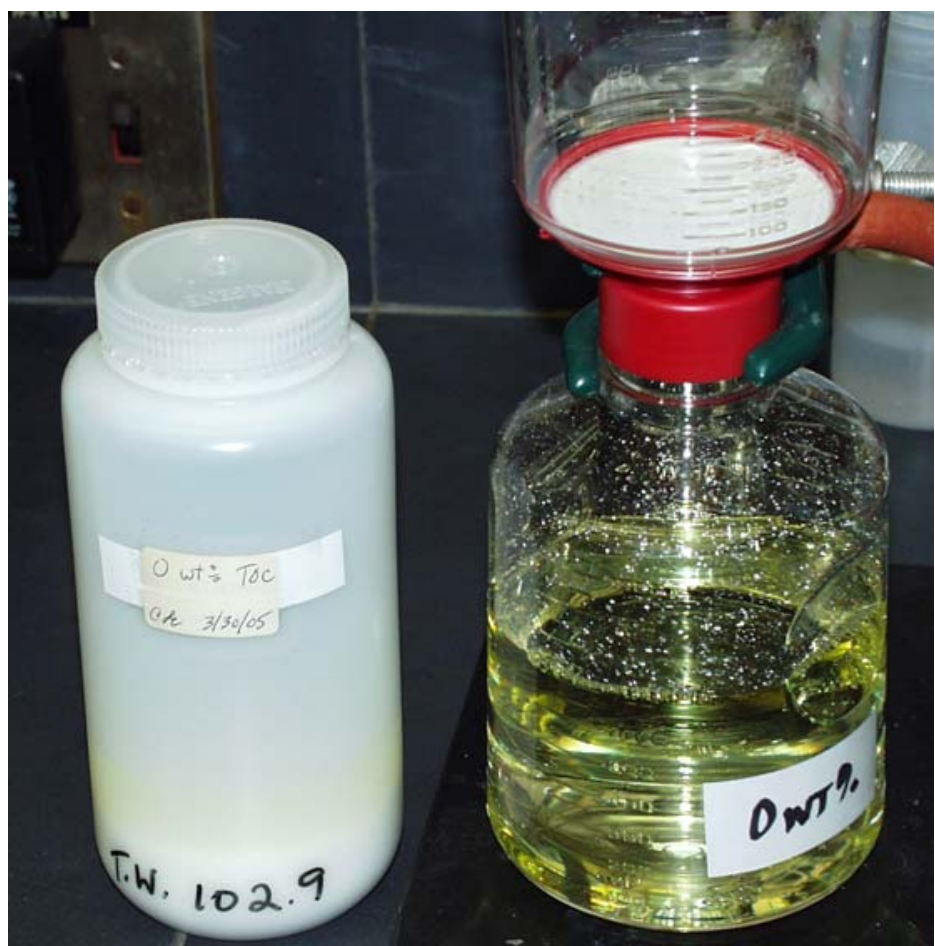

Figure 3-2. Filtration of the base simulant

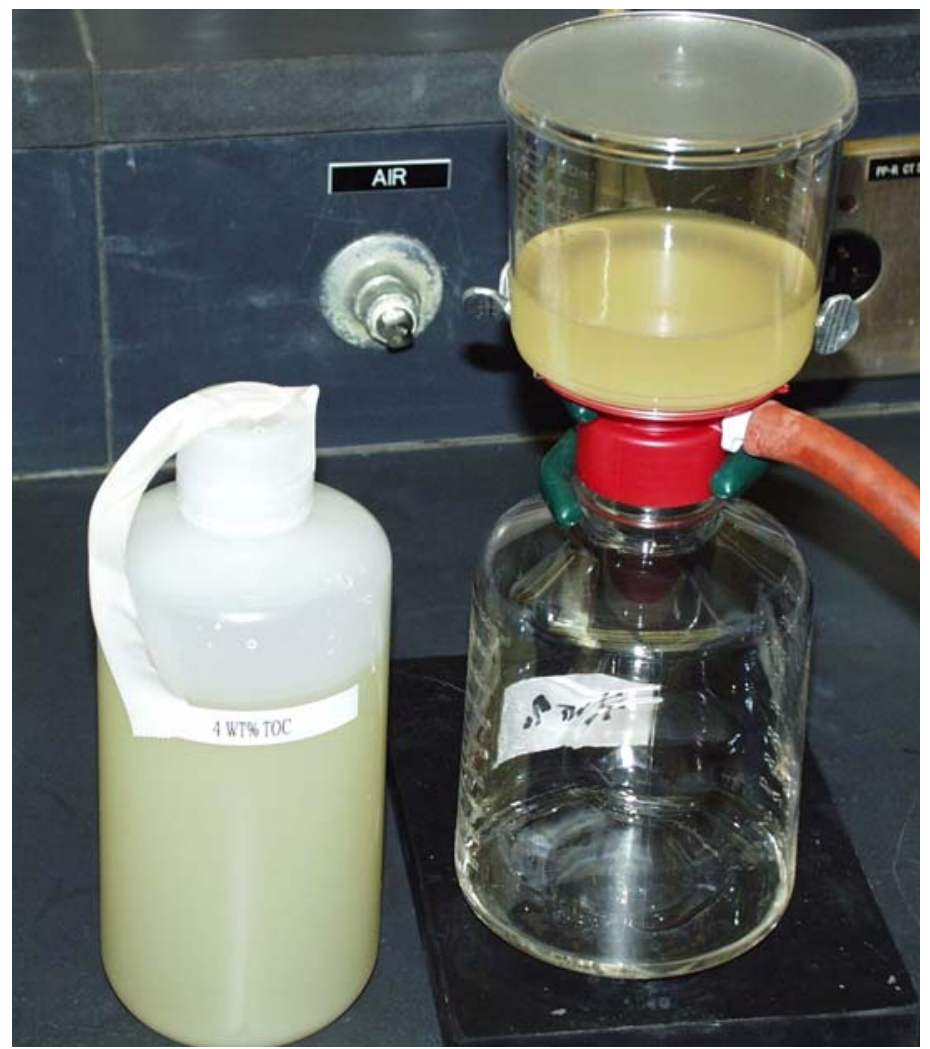

Figure 3-3. Filtration of the native simulant 
WSRC-TR-2005-00281, REVISION 0

SRNL-RPP-2005-00040, REVISION 0

Table 3-2. Base Simulant Filtrate Analysis

\begin{tabular}{|c|c|c|c|c|}
\hline 0 wt\% TOC & $\begin{array}{c}\text { Measured } \\
\text { (mg/L) }\end{array}$ & $\begin{array}{c}\text { Measured } \\
\text { (mg/L) }\end{array}$ & $\begin{array}{c}\text { Average } \\
\text { (mg/L) }\end{array}$ & Avg./Batch* \\
\hline Component & $\begin{array}{c}\text { \# 217569 } \\
\text { duplicate 1 }\end{array}$ & $\begin{array}{c}\text { \# 217570 } \\
\text { duplicate 2 }\end{array}$ & & \\
\hline Aluminum & 12200 & 11200 & 11700 & 0.43 \\
\hline & $(0.93 \mathrm{wt} \%)$ & $(0.85 \mathrm{wt} \%)$ & $(0.89 \mathrm{wt} \%)$ & \\
\hline Cadmium & $<4.17$ & 4.17 & & \\
\hline Chloride & $<20$ & $<20$ & & \\
\hline Chromium & 6.33 & 6.8 & 6.6 & \\
\hline Copper & $<2.83$ & $<2.83$ & & \\
\hline Iron & $<4.07$ & $<4.07$ & & \\
\hline Molybdenum & $<18.8$ & $<18.8$ & & \\
\hline HEDTA & $<50$ & $<50$ & & \\
\hline Nickel & $<3.8$ & $<3.8$ & & \\
\hline Nitrate & 163000 & 165000 & 164000 & 0.88 \\
\hline & $\mathbf{( 2 . 6 2 9} \mathbf{M})$ & $\mathbf{( 2 . 6 6 1} \mathbf{M})$ & $\mathbf{( 2 . 6 5} \mathbf{M})$ & \\
\hline Nitrite & 118000 & 121000 & 119500 & 0.87 \\
\hline & $\mathbf{( 2 . 5 6 5} \mathbf{M})$ & $\mathbf{( 2 . 6 3 0 ~ M )}$ & $\mathbf{( 2 . 6 0} \mathbf{M})$ & \\
\hline Sodium & 167000 & 182000 & 174500 & 1.07 \\
\hline Sulfate & $<50$ & $<50$ & & \\
\hline Zinc & $<0.697$ & $<0.697$ & & \\
\hline
\end{tabular}

* Note: If all additives in the original simulants had been completely soluble, then the Avg./Batch values would all be 1.0. 
WSRC-TR-2005-00281, REVISION 0

SRNL-RPP-2005-00040, REVISION 0

Table 3-3. Native Simulant Filtrate Analysis

\begin{tabular}{|c|c|c|c|c|}
\hline 4 wt $\%$ TOC & $\begin{array}{c}\text { Measured } \\
(\mathrm{mg} / \mathrm{L})\end{array}$ & $\begin{array}{c}\text { Measured } \\
(\mathrm{mg} / \mathrm{L})\end{array}$ & $\begin{array}{c}\text { Average } \\
\text { (mg/L) }\end{array}$ & Avg./Batch* \\
\hline Component & $\begin{array}{c}\text { \# } 217571 \\
\text { duplicate } 1\end{array}$ & $\begin{array}{c}\text { \# } 217572 \\
\text { duplicate } 2\end{array}$ & & \\
\hline \multirow[t]{2}{*}{ Aluminum } & 21300 & 20800 & 21050 & 0.78 \\
\hline & $(1.62 w t \%)$ & $(1.58 w t \%)$ & $(1.60 w t \%)$ & \\
\hline Cadmium & $<4.17$ & 4.2 & & \\
\hline Chloride & $<20$ & $<20$ & & \\
\hline Chromium & 5.76 & 7 & 6.4 & \\
\hline Copper & 4.5 & 3.78 & 4.1 & \\
\hline Glycolate & 27000 & 25000 & 26000 & 0.20 \\
\hline Iron & 4.19 & $<4.07$ & & \\
\hline Molybdenum & $<18.8$ & $<18.8$ & & \\
\hline HEDTA & 4590 & 4634 & 4612 & 0.14 \\
\hline Nickel & $<3.8$ & $<3.8$ & & \\
\hline \multirow[t]{2}{*}{ Nitrate } & 166000 & 163000 & 164500 & 0.88 \\
\hline & $(2.677 \mathrm{M})$ & $(2.629 \mathrm{M})$ & $(2.65 \mathrm{M})$ & \\
\hline \multirow[t]{2}{*}{ Nitrite } & 119000 & 115000 & 117000 & 0.85 \\
\hline & $(2.587 \mathrm{M})$ & $(2.500 \mathrm{M})$ & $(2.54 \mathrm{M})$ & \\
\hline Sodium & 222000 & 215000 & 218500 & 1.03 \\
\hline Sulfate & $<50$ & $<50$ & & \\
\hline \multirow[t]{2}{*}{ TOC } & 16800 & 18200 & 17500 & 0.31 \\
\hline & $(1.18 w t \%)$ & $(1.28 \mathrm{wt} \%)$ & $(1.23 \mathrm{wt} \%)$ & \\
\hline Zinc & $<1.98$ & 2.55 & & \\
\hline
\end{tabular}

* Note: If all additives in the original simulants had been completely soluble, then the Avg./Batch values would all be 1.0. 
Table 3-4. AN-107 Simulant Partial Analysis *

\begin{tabular}{|c|c|c|c|}
\hline \multicolumn{2}{|c|}{ AN107 Simulant } & & \\
\hline Analyte & (mg/L) & & \\
\hline $\mathrm{Al}$ & 236 & 0.018 & wt $\%$ \\
\hline $\mathrm{Na}$ & 131,057 & 5.72 & Molar \\
\hline Nitrate & 145,186 & 2.342 & Molar \\
\hline Nitrite & 38,751 & 0.842 & Molar \\
\hline TOC (native) & 11,070 & 0.868 & $\mathrm{wt} \%$ \\
\hline TOC (AFA)** & - & 0.200 & $\mathrm{wt} \%$ \\
\hline TOC (total) & - & 1.068 & $\mathrm{wt} \%$ \\
\hline & Molar & - & - \\
\hline Tot $\mathrm{OH}^{-}$ & 1.39 & - & - \\
\hline Free $\mathrm{OH}^{-}$ & 0.55 & - & - \\
\hline Density & $1.276 \mathrm{~g} / \mathrm{mL}$ & - & - \\
\hline
\end{tabular}

* Full analyses of this simulant presented in Tables 12 and 13 of Saito et al. (2001) ** Q2-3183A antifoam added to the AN-107 simulant at $0.5 \mathrm{wt} \%$ antifoam

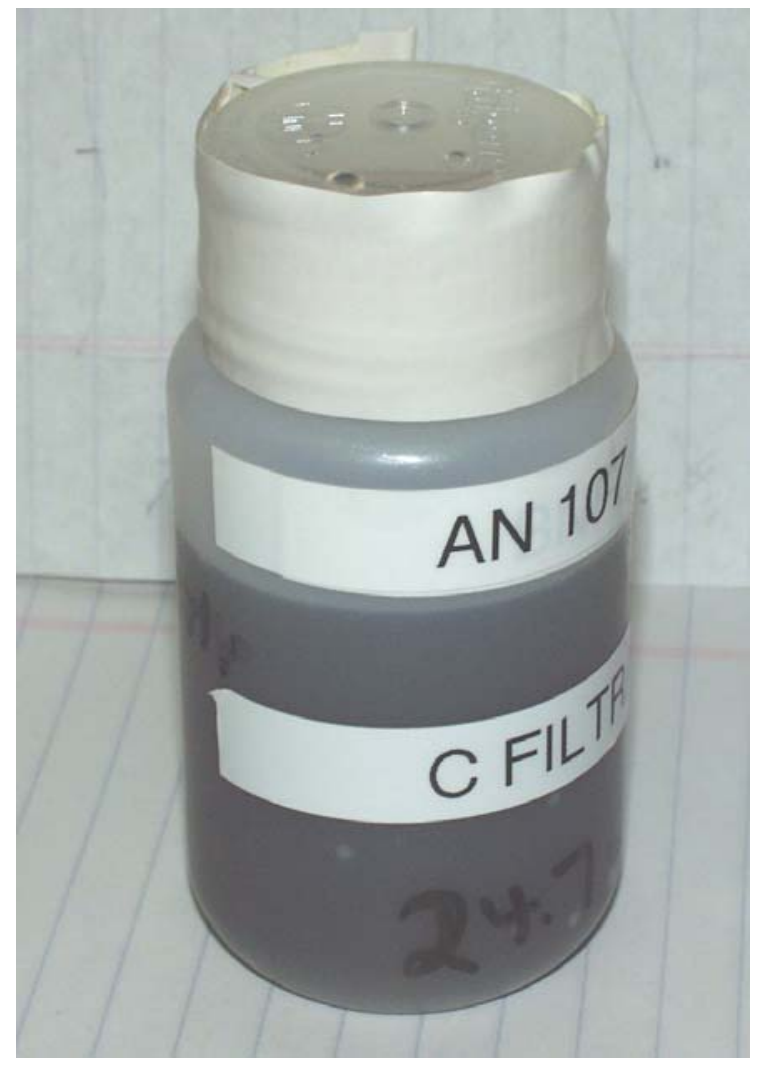

Figure 3-4. AN-107 Envelope C Simulant 


\subsection{DOSIMETRY}

Aqueous ferrous sulphate Fricke dosimetry solutions were prepared per the composition given in Table 3-5. The dosimetry solutions were placed in identical steel vessels and the same aluminum block that was used for simulant irradiation in this study. The aluminum block containing the steel vessels with Fricke solutions was irradiated for one, two and three minutes in the identical position as was used for simulant irradiations. The absorbance of the irradiated solutions was then measured using a Tidus II Spectrometer instrument at $304 \mathrm{~nm}$, which is the maximum absorbance wavelength for the oxidized ferric $\left(\mathrm{Fe}^{+3}\right)$ ion.

A plot of the absorbance vs. exposure time is shown in Figure 3-5. The slope of the absorbance $(A)$ vs. exposure time gives a slope of 0.0018 absorbance units per sec. This slope can be used in the following equation (eq. \# 3.38 from pg. 99 of Spinks and Woods $1990)$ to calculate the dose rate $(D)$ in units of grays (Gy).

$D(\mathrm{~Gy})=(2.77 \times \Delta A) / \mathrm{L}$,

With L equal to the optical pathlength of absorbance cell in meters.

Substituting in the measured change in absorbance per time and converting from grays to rads gives:

$$
\begin{aligned}
& D(\mathrm{rad} / \mathrm{hr})=((2.77 \times(0.0018 / \mathrm{sec}) \times 3600 \mathrm{sec} / \mathrm{hr} \times(1 \mathrm{rad} / 0.01 \mathrm{~Gy})) / 1 \mathrm{~cm}) * 100 \mathrm{~cm} / \mathrm{m} \\
& D(\mathrm{rad} / \mathrm{hr})=1.8 \mathrm{E}+05 \mathrm{rad} / \mathrm{hr}
\end{aligned}
$$

Error analysis of the best fit straight lines through the six data points indicates an error of $\pm 10 \%$ for the measured dose rate. 
Table 3-5. Ferrous Sulphate 'Fricke Dosimeter'

\begin{tabular}{|c|c|c|}
\hline Chemical & Amount & Vendor/Lot\# \\
\hline $\begin{array}{c}\text { Concentrated } \\
\mathrm{H}_{2} \mathrm{SO}_{4}\end{array}$ & $5.7 \mathrm{~mL}$ & Fisher/\#025810 \\
\hline $\mathrm{FeSO}_{4} \cdot 7 \mathrm{H}_{2} \mathrm{O}$ & $0.070 \mathrm{~g}$ & Fisher/\#984410 \\
\hline $\mathrm{NaCl}$ & $0.015 \mathrm{~g}$ & Fisher/\#995497 \\
\hline $\begin{array}{c}\text { Deionized } \\
\text { Water }\end{array}$ & $\begin{array}{c}\text { Added to make } \\
0.25 \mathrm{~L} \text { total } \\
\text { volume }\end{array}$ & $\begin{array}{c}\text { MilliQ filtration } \\
\text { system }\end{array}$ \\
\hline
\end{tabular}

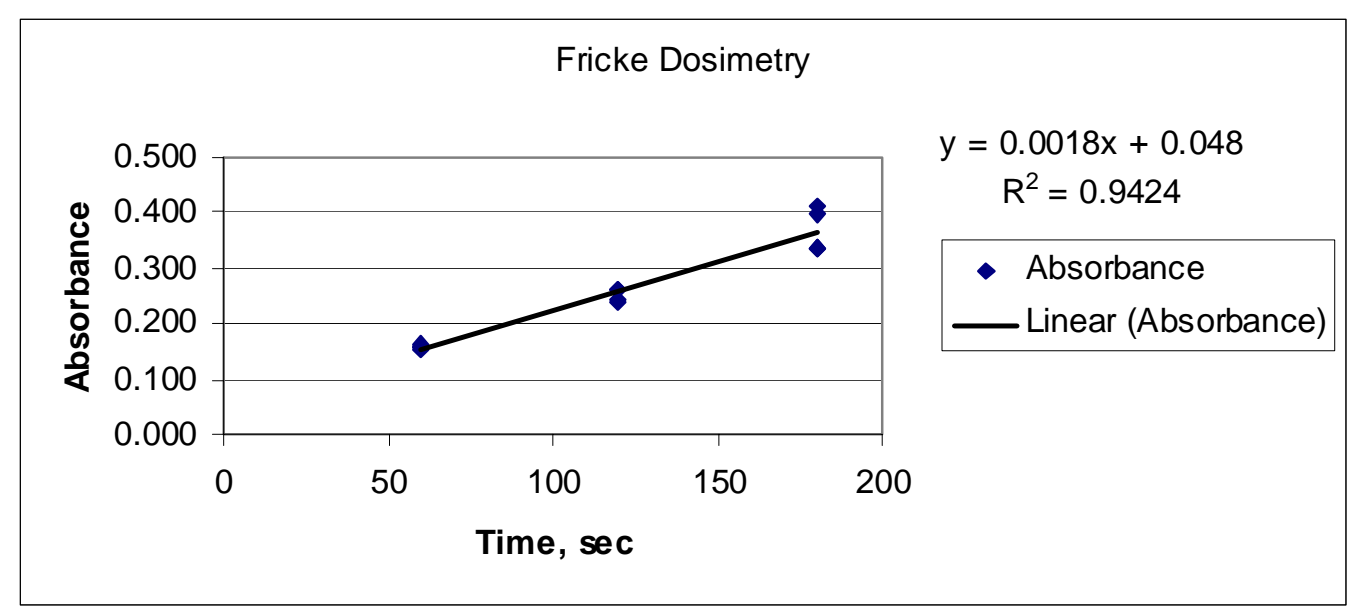

Figure 3-5. Fricke Dosimetry Absorbance vs. Time Plot 
WSRC-TR-2005-00281, REVISION 0

SRNL-RPP-2005-00040, REVISION 0

\subsection{MEASUREMENT OF TOC CONTENT OF Q2-3183A ANTIFOAM}

Table 3-6 shows the TOC analyses for the neat Q2-3183A antifoam by ADS. Three different dilutions were performed and a triplicate data set was measured for each dilution. The grand average result was $39.7 \mathrm{wt} \%$ TOC with a $12.3 \%$ relative standard deviation. Thus the reported value is $39.7 \mathrm{wt} \%$ TOC $\pm 4.9 \mathrm{wt} \%$. The pre and post calibration $100 \mathrm{ppm}$ TOC standards all measured in the acceptable range $(100 \mathrm{ppm} \pm 10 \%)$ of $99-105 \mathrm{ppm}$. The 39.7 $\mathrm{wt} \%$ TOC measured for Q2-3183A antifoam is reasonable considering the constituents listed in Table 2-1. The primary organic species are PDMS (with a calculated monomer $\left.\left(\mathrm{CH}_{3}\right)_{2} \mathrm{SiO}\right)$ TOC of $40 \mathrm{wt} \%$ ) and PPG (with a calculated monomer $\left(\mathrm{C}_{3} \mathrm{H}_{6} \mathrm{O}\right)$ TOC of $62 \mathrm{wt} \%)$.

Table 3-6. Measurement of TOC in Q2-3183A

\begin{tabular}{|l|c|c|c|c|c|c|c|c|}
\hline & & wt\% C & Measured & & \multicolumn{2}{|c|}{ Dilution } & \multicolumn{2}{|c|}{ Raw data, mg C / L } \\
\hline & & $\begin{array}{l}\text { Average } \\
\text { ppm }\end{array}$ & \%RSD & Factor & & & \\
\hline $\begin{array}{l}\text { CCV (Cal } \\
\text { verification) }\end{array}$ & $100 \mathrm{ppm}$ & - & - & - & 1 & 104.3 & 101.2 & - \\
\hline $\begin{array}{l}\text { Q2-3183A } \\
\text { antifoam }\end{array}$ & - & 45.2 & 452282 & 8.3 & 20800 & 23.414 & 21.987 & 19.832 \\
\hline $\begin{array}{l}\text { Q2-3183A } \\
\text { antifoam }\end{array}$ & - & 35.6 & 355547 & 6.7 & 10400 & 37.256 & 33.986 & 33.762 \\
\hline $\begin{array}{l}\text { Q2-3183A } \\
\text { antifoam }\end{array}$ & - & 38.4 & 383564 & 2.0 & 5200 & 75.412 & 73.196 & 72.679 \\
\hline Post-CCV & $100 \mathrm{ppm}$ & - & - & - & 1 & 99.80 & 104.70 & - \\
\hline & Avg.-> & 39.7 & & 12.3 & \multicolumn{2}{|c|}{$(\%$ RSD of 10 measurements $)$} \\
\hline
\end{tabular}


WSRC-TR-2005-00281, REVISION 0

SRNL-RPP-2005-00040, REVISION 0

\subsection{HYDROGEN MEASUREMENTS VIA MASS SPECTROSCOPY}

Hydrogen was measured in the gas collected in steel sample bulbs. The mass spectrometer was calibrated by a standard gas with $1 \mathrm{vol} \%$ hydrogen $(10,000 \mathrm{ppm})$. A blank system was set up that contained no organic in the base simulant filtrate. This blank system was similar to all of the others exposed in the gamma irradiation device. Table 3-7 provides data measured from the standard and blank systems. All hydrogen measurements were within 4\% of the target. Other components in the standard gas were measured at mass $=16$ for methane and some residual atomic oxygen from the mass spectroscopy method, mass $=28$ for nitrogen and carbon monoxide, mass $=32$ for oxygen and mass $=44$ for carbon dioxide. Trace amounts of hydrogen were measured in the blank system at $5-9 \mathrm{ppm}$. As expected the blanks consist primarily of air with the nominal oxygen $(21 \mathrm{vol} \%)$ to nitrogen $(78 \mathrm{vol} \%)$ ratio of $\sim 0.27$. The quantification limit for hydrogen was estimated from the mass spectroscopy spectra signal (peak and area under curve) for hydrogen at about $100 \mathrm{X}$ below the standard-gas level of $1 \mathrm{vol} \%(10,000 \mathrm{ppm})$, or about $0.01 \mathrm{vol} \%=100 \mathrm{ppm}$.

Table 3-7. Mass Spectroscopy Gas Component Measurements in Blank and Standard

\begin{tabular}{|c|c|c|c|c|c|c|c|}
\hline Date & System & Target* & Measured & Mass 16 & Mass 28 & Mass 32 & Mass 44 \\
\hline & & Vol\% $\mathrm{H}_{2}$ & Vol\% $\mathrm{H}_{2}$ & $\mathrm{CH}_{4} / \mathrm{O}$ & $\mathrm{N}_{2} / \mathrm{CO}$ & $\mathbf{O}_{2}$ & $\mathrm{CO}_{2}$ \\
\hline $4 / 20 / 05$ & Std. & 1.0 & 1.0282 & 0.96958 & 95.9810 & $1.0346 \%$ & 0.98659 \\
\hline $4 / 20 / 05$ & Blank & 0 & 0.00095 & 1.58 & 78.0393 & 20.3139 & 0.065 \\
\hline $5 / 05 / 05$ & Blank & 0 & 0.00054 & 1.55 & 77.3388 & 20.9585 & 0.1497 \\
\hline $5 / 05 / 05$ & Std. & 1.0 & 1.0448 & 1.0116 & 95.9523 & 1.0054 & 0.98589 \\
\hline $5 / 05 / 05$ & Std. & 1.0 & 0.9964 .5 & 1.0296 & 95.5209 & $1.3264 \%$ & 1.1266 \\
\hline
\end{tabular}

* Standard gas contained 1 vol\% each of $\mathrm{H}_{2}, \mathrm{CH}_{4}, \mathrm{CO}, \mathrm{O}_{2}$ and $\mathrm{CO}_{2}$ in $95 \% \mathrm{~N}_{2}$ 
WSRC-TR-2005-00281, REVISION 0

SRNL-RPP-2005-00040, REVISION 0

\subsection{INITIAL RADIOLYSIS/THERMOLYSIS TESTING}

Initial radiolysis/thermolysis testing used the base simulant, the base simulant with low and high antifoam addition, and the $4 \mathrm{wt} \%$ TOC simulant. Table 3-8 shows their compositions. The base simulant and the $4 \mathrm{wt} \%$ TOC native simulant were prepared as single samples and the low-antifoam/base simulant and high antifoam/base simulant were prepared in duplicate. These systems were irradiated and heated for 12 days and pressures and temperatures were monitored and recorded. Figure 3-6 shows some of the pressure vs. time data for these systems. The total pressurization increases in the order of low antifoam, high antifoam, base simulant and native simulant. Linear least squares fits through the data indicate excellent linearity since the $\mathrm{R}^{2}$ coefficients are at least 0.999 .

After 12 days of exposure the systems were allowed to cool to ambient temperature and the radiation source was removed. Gases collected at the end of testing at ambient temperature were analyzed by mass spectroscopy and the results are shown in Table 3-9. The hydrogen components were input into the ideal gas equation along with the system pressure, volume and temperature to calculate the moles of hydrogen produced during testing. The moles of hydrogen were used along with the total mass tested and the total time of testing to calculate the hydrogen generation rates (HGR) for each system. These values are also shown in Table 3-9. A sample calculation for the HGRs is given in Appendix A. All of the simulant parameters and the dose rate and temperature were input into the WTP HGR correlation (Appendix C) to predict HGRs for these systems. This calculation treats the TOC from the antifoam in the same manner as any native TOC in the simulant.

Table 3-9 shows these predicted HGRs for comparison to the measured values. The nominal variability in the WTP HGR correlation is approximately \pm 3 X. (Sherwood and Stock 2004). Lower HGRs are calculated by assuming complete immiscible antifoam agent. The only hydrogen contribution from immiscible antifoam is a minor radiolytic term due to direct radiolytic interaction/decomposition of the immiscible antifoam. Visual observation of the pre and post tested samples indicated immiscible antifoam on the top surface of the simulants. No attempts were made for this study to investigate the degree of miscibility for the antifoam solution with the various caustic simulants.

There is good agreement between the measured and predicted HGRs for the base simulant with no TOC added. The measured HGR of $3.2 \mathrm{E}-4 \mathrm{~g}-\mathrm{mol} / \mathrm{kg} /$ day compared to the predicted value of $1.7 \mathrm{E}-4 \mathrm{~g}-\mathrm{mol} / \mathrm{kg} /$ day gives a ratio of predicted $/ \mathrm{measured}$ of 0.5 . The hydrogen produced in this system should be exclusively from the radiolysis of water as there is no other hydrocarbon source for hydrogen production from other pathways. Table 3-9 shows that the predicted HGR for the native organic simulant (4.6E-3 g-mol $/ \mathrm{kg} /$ day) is about six times higher than the measured value of $8.2 \mathrm{E}-4 \mathrm{~g}-\mathrm{mol} / \mathrm{kg} / \mathrm{day}$. The hydrogen sources for this native organic-containing simulant are water radiolysis, organic radiolysis, and organic thermolysis. 
WSRC-TR-2005-00281, REVISION 0

SRNL-RPP-2005-00040, REVISION 0

Table 3-8. Simulant Systems for Radiolysis/Thermolysis Initial Testing

\begin{tabular}{|c|c|c|c|c|c|c|c|c|}
\hline & & & V56 & V57 & V58 & V59 & V60 & V61 \\
\hline $\begin{array}{c}0 \mathrm{wt} \% \text { TOC } \\
\text { simulant }\end{array}$ & amount added: & (grams) & 19.5474 & 16.943 & 16.8433 & 18.2713 & 18.3272 & - \\
\hline $\begin{array}{c}4 \mathrm{wt} \% \text { TOC } \\
\text { simulant }\end{array}$ & amount added: & (grams) & - & - & - & - & - & 21.0993 \\
\hline AFA & amount added: & (grams) & 0 & 1.7921 & 1.7726 & 0.4917 & 0.4684 & 0 \\
\hline Total mass & & (grams) & 19.5474 & 18.7351 & 18.6159 & 18.763 & 18.7956 & 21.0993 \\
\hline Total volume* & & $(\mathrm{mL})$ & 14.8277 & 14.6443 & 14.5491 & 14.3514 & 14.3705 & 14.8461 \\
\hline TOC(AFA) & $(=0.397 * \mathrm{AFA})$ & (grams) & & 0.7115 & 0.7037 & 0.1952 & 0.1860 & - \\
\hline $\mathrm{wt} \%$ AFA & & - & - & 9.6 & 9.5 & 2.6 & 2.5 & - \\
\hline $\mathrm{wt} \%$ TOC & & - & - & 3.8 & 3.8 & 1.0 & 1.0 & - \\
\hline
\end{tabular}

$* 4 \mathrm{wt} \%$ simulant density $=1.4212 \mathrm{~g} / \mathrm{mL} ; 0 \mathrm{wt} \%$ simulant density $=1.3183 \mathrm{~g} / \mathrm{mL}$;

pure antifoam density $=1.0 \mathrm{~g} / \mathrm{mL}$

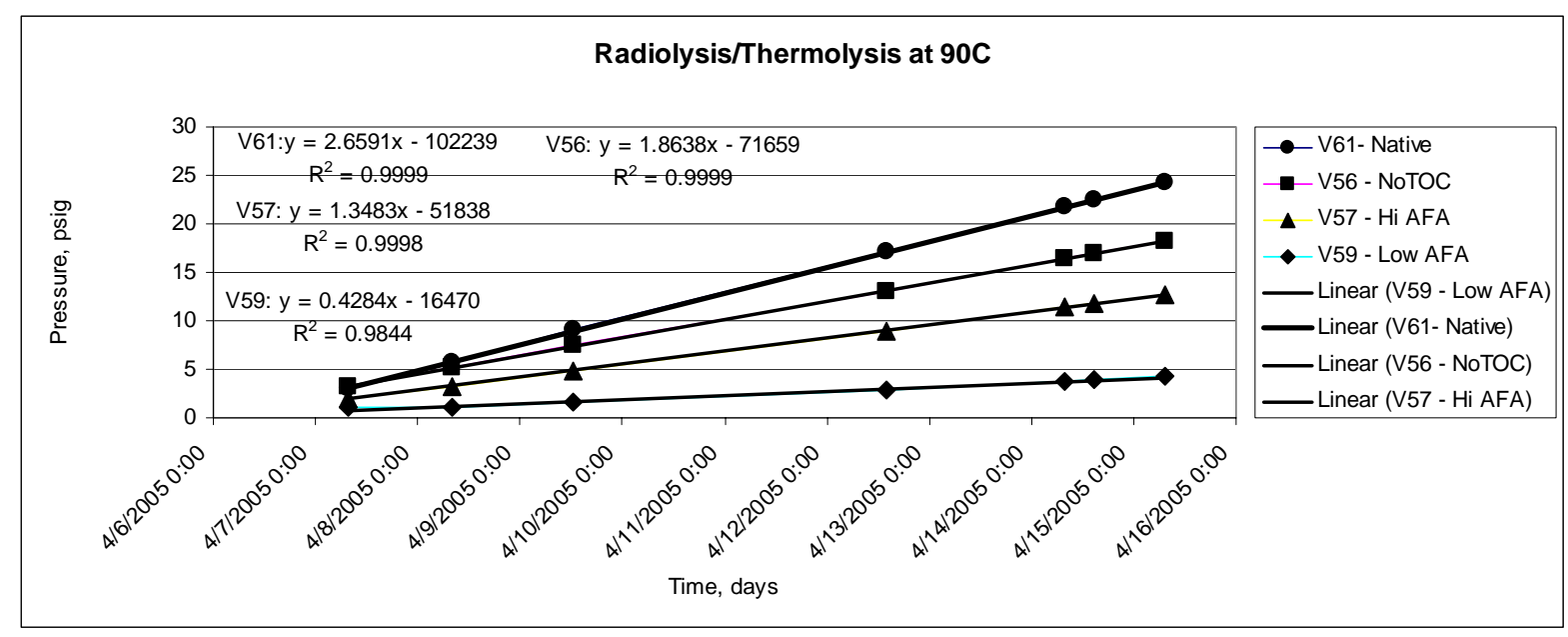

Figure 3-6. Pressure vs. Time Plots for Radiolysis/Thermolysis Initial Testing 
WSRC-TR-2005-00281, REVISION 0

SRNL-RPP-2005-00040, REVISION 0

Table 3-9. Hydrogen and HGRs for Radiolysis/Thermolysis Initial Testing

\begin{tabular}{|l|c|c|c|c|c|c|}
\hline $\begin{array}{l}\text { Radiolysis/Thermolysis } \\
\text { InitialTesting }\end{array}$ & Units & No TOC & High AFA & $\begin{array}{l}\text { High AFA } \\
\text { (duplicate) }\end{array}$ & Low AFA & $\begin{array}{l}\text { Low AFA* } \\
\text { (duplicate) }\end{array}$ \\
\hline Measured Hydrogen & vol \% & $\mathbf{4 . 6 6}$ & $\mathbf{2 0 . 4 4}$ & $\mathbf{1 9 . 7 9}$ & $\mathbf{6 . 9 9}$ & $\mathbf{1 8 . 9 0}$ \\
\hline $\begin{array}{l}\text { Measured HGR } \\
\text { Rad/Therm }\end{array}$ & g-mol/kg/day & 3.23E-04 & & 10.01 \\
\hline $\begin{array}{l}\text { Average Measured HGR } \\
\text { Rad/Therm }\end{array}$ & g-mol/kg/day
\end{tabular}

* Note: this low AFA system developed a leak during testing.

${ }^{\$}$ From Appendix C, Predicted HGR Rad/Therm (AFA miscible) $=\mathrm{HGR}_{\mathrm{LAW} 0}+\mathrm{HGR}_{-} \mathrm{imi}_{\mathrm{AFA} 0}+\mathrm{HGR}_{\mathrm{AFA} 0}$

${ }^{\$ \$}$ From Appendix C, Predicted HGR Rad/Therm $($ AFA immiscible $)=\mathrm{HGR}_{\mathrm{LAW} 0}+\mathrm{HGR}$ imi $_{\mathrm{AFA} 0}$ 
WSRC-TR-2005-00281, REVISION 0

SRNL-RPP-2005-00040, REVISION 0

\subsection{REPEAT RADIOLYSIS/THERMOLYSIS TESTING}

At the end of the initial testing period it was concluded by SRNL and WTP R\&T personnel that further testing should be investigated using repeated systems (high and low antifoam) in addition to a new AN-107 simulant. The further radiolysis/thermolysis testing used similar duplicate simulant systems from the initial tests (duplicate low antifoam/base simulant and duplicate high antifoam/base simulant) along with a duplicate AN-107 simulant that contained relatively low $0.5 \mathrm{wt} \%$ amount of antifoam. Table 3-10 shows the details of these simulant compositions. These systems were prepared with fresh solutions and new sample vessels and were irradiated and heated for 5 days with pressure and temperature recording. Figure 3-7 shows some of the pressure vs. time data for these systems. The total pressurization is shown to increase in the order of low antifoam to high antifoam to AN-107 simulant. Note from Figure 3-8 that all three duplicate systems show good precision in the total pressure vs. time plots indicating no suspected leaks in the six systems during 5 days of testing.

Gases were collected from these radiolysis/thermolysis tests in the same manner as initial testing and the results are shown in Table 3-11. Measured and predicted HGRs are shown in Table 3-11. Three of the systems were sampled a second time for gas analysis to investigate residual gases contained in the headspace of the systems. The second analyses of the vessel headspace indicated that varying amounts of hydrogen were still present in the system headspaces after the initial gas sampling. Second analyses showed that between $30 \%$ and $90 \%$ of the original hydrogen remained in the system headspace after initial sampling and equilibration to atmospheric pressure.

Table 3-11 shows that the predicted HGR for the AN-107 native organic-containing simulant (3.8E-3 g-mol/ $\mathrm{kg} /$ day) is about 5.8 times the measured value of $6.3 \mathrm{E}-4 \mathrm{~g}-\mathrm{mol} / \mathrm{kg} /$ day. The hydrogen sources for this native organic-containing and antifoam-containing AN-107

simulant are water radiolysis, organic radiolysis (from native organic and antifoam TOC) and organic thermolysis (from native organic and antifoam TOC). Since this AN-107 simulant contained relatively small amounts of antifoam $(\sim 0.5 \mathrm{wt} \%)$ vs. the other antifoam systems studied, there is very little difference in the predicted HGRs if one considers the antifoam as either entirely miscible $(\mathrm{HGR}=3.8 \mathrm{E}-3 \mathrm{~g}-\mathrm{mol} / \mathrm{kg} /$ day $)$ or entirely immiscible

$(\mathrm{HGR}=3.2 \mathrm{E}-3 \mathrm{~g}-\mathrm{mol} / \mathrm{kg} / \mathrm{day})$. 
WSRC-TR-2005-00281, REVISION 0

SRNL-RPP-2005-00040, REVISION 0

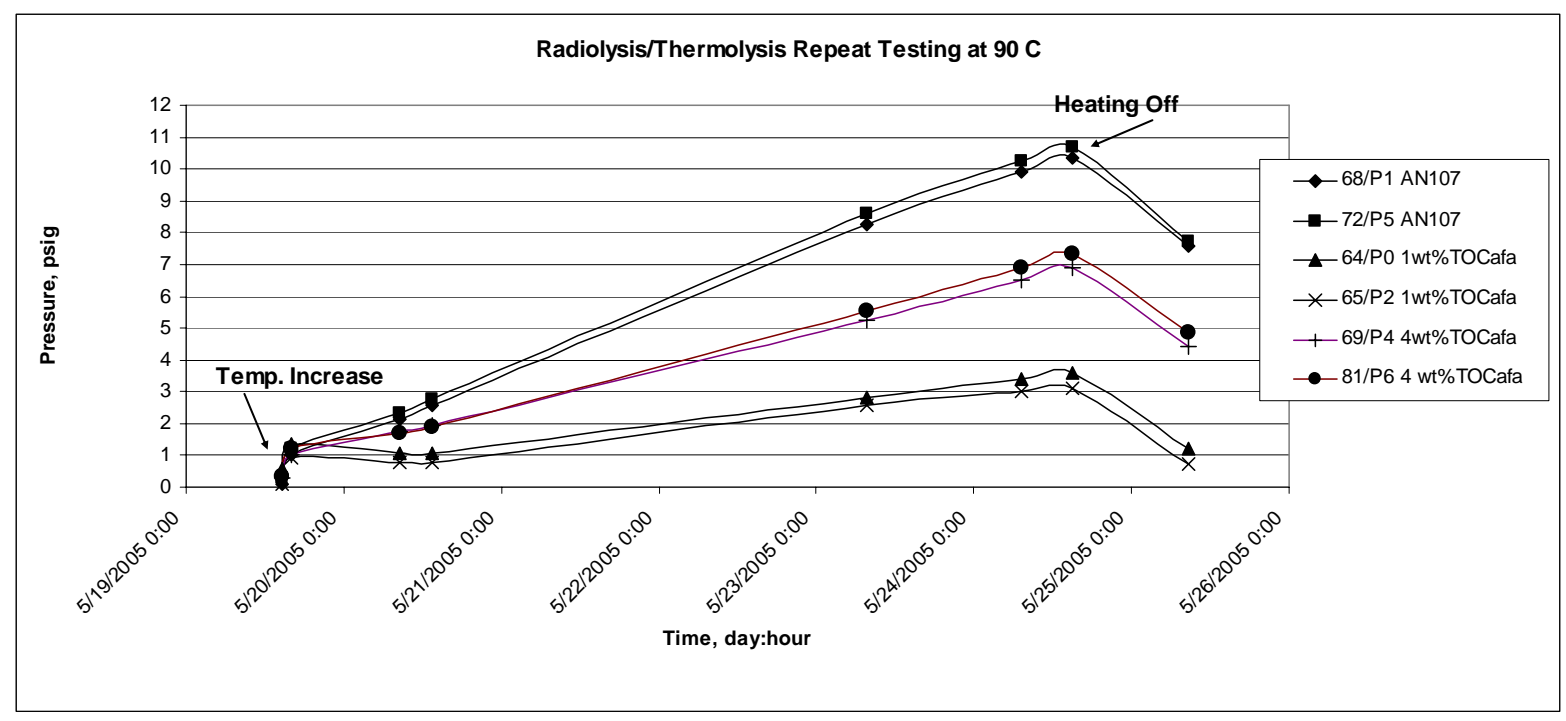

Figure 3-7. Pressure vs. Time Plots for Radiolysis/Thermolysis Repeat Testing

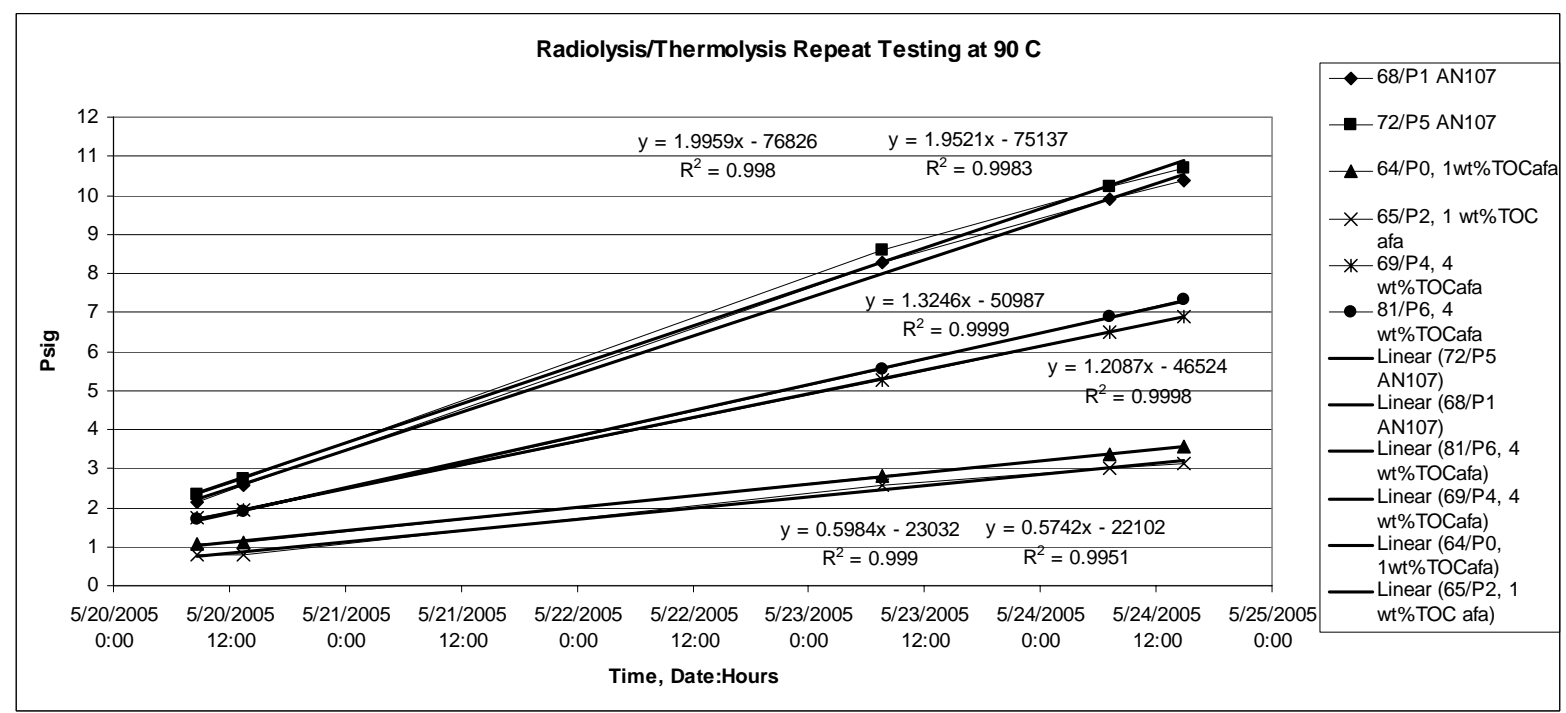

Figure 3-8. Pressure vs. Time Plots for Radiolysis/Thermolysis Repeat Testing Showing Best Linear Fits 
WSRC-TR-2005-00281, REVISION 0

SRNL-RPP-2005-00040, REVISION 0

Table 3-10. Simulant Systems for Radiolysis/Thermolysis Repeat Testing

\begin{tabular}{|c|c|c|c|c|c|c|c|c|}
\hline & & & V68 & V72 & V69 & V81 & V64 & V65 \\
\hline $\begin{array}{c}0 \mathrm{wt} \% \text { TOC } \\
\text { simulant }\end{array}$ & amount added: & (grams) & - & - & 17.0923 & 17.0403 & 18.5072 & 18.3631 \\
\hline AN107 Sim & amount added: & (grams) & 19.1442 & 19.1199 & - & - & - & - \\
\hline AFA & amount added: & (grams) & 0.0988 & 0.1085 & 1.8271 & 1.8057 & 0.5364 & 0.5003 \\
\hline Total mass & & (grams) & 19.243 & 19.2284 & 18.9194 & 18.846 & 19.0436 & 18.8634 \\
\hline Total volume* & & $(\mathrm{mL})$ & 15.1021 & 15.0927 & 14.7925 & 14.7317 & 14.5751 & 14.4297 \\
\hline TOC(AFA) & $(=0.397 * \mathrm{AFA})$ & (grams) & 0.0392 & 0.0431 & 0.7254 & 0.7169 & 0.2130 & 0.1986 \\
\hline $\mathrm{wt} \% \mathrm{AFA}$ & & - & 0.51 & 0.56 & 9.66 & 9.58 & 2.82 & 2.65 \\
\hline $\mathrm{wt} \%$ TOC(AFA) & & - & 0.20 & 0.22 & 3.83 & 3.80 & 1.12 & 1.05 \\
\hline $\mathrm{wt} \%$ TOC(Total) & & - & 1.07 & 1.09 & & & & \\
\hline
\end{tabular}

* $0 \mathrm{wt} \%$ simulant density $=1.3183 \mathrm{~g} / \mathrm{mL} ;$ AN107 simulant density $=1.276 \mathrm{~g} / \mathrm{mL}$; pure antifoam density $=1.0 \mathrm{~g} / \mathrm{mL}$

Table 3-11. Hydrogen and HRGs for Radiolysis/Thermolysis Repeat Testing

\begin{tabular}{|c|c|c|c|c|c|c|c|}
\hline $\begin{array}{l}\text { Radiolysis/Thermolysis } \\
\text { Repeat Testing }\end{array}$ & Units & $\begin{array}{l}\text { AN107, } \\
0.5 w t \% \\
\text { AFA }\end{array}$ & $\begin{array}{l}\text { AN107, } \\
\text { 0.5wt } \% \\
\text { AFA }\end{array}$ & High AFA & $\begin{array}{r}\text { High AFA } \\
\text { (duplicate) }\end{array}$ & Low AFA & $\begin{array}{l}\text { Low AFA } \\
\text { (duplicate }\end{array}$ \\
\hline Measured Hydrogen & vol \% & 5.79 & 6.09 & 9.42 & 13.32 & 2.43 & 2.23 \\
\hline $\begin{array}{l}\text { Measured HGR } \\
\text { Rad/Therm }\end{array}$ & $\mathrm{g}-\mathrm{mol} / \mathrm{kg} / \mathrm{day}$ & 6.31E-04 & $6.69 \mathrm{E}-04$ & 8.96E-04 & 1.30E-03 & 1.91E-04 & 1.72E-04 \\
\hline $\begin{array}{l}\text { Average Measured HGR } \\
\text { Rad/Therm }\end{array}$ & g-mol $/ \mathrm{kg} /$ day & $6.50 \mathrm{E}-04$ & - & 1.10E-03 & - & 1.81E-04 & - \\
\hline $\begin{array}{l}\text { Predicted HGR } \\
\text { Rad/Therm (AFA } \\
\text { miscible) }\end{array}$ & g-mol $/ \mathrm{kg} / \mathrm{day}$ & $3.79 \mathrm{E}-03$ & - & $1.28 \mathrm{E}-02$ & - & $3.61 \mathrm{E}-03$ & - \\
\hline $\begin{array}{l}\text { Predicted HGR } \\
\text { Rad/Therm (AFA } \\
\text { immiscible) } \$ \$\end{array}$ & g-mol $/ \mathrm{kg} /$ day & $3.17 \mathrm{E}-03$ & - & $1.05 \mathrm{E}-03$ & - & $3.90 \mathrm{E}-04$ & - \\
\hline $\begin{array}{l}\text { Ratio: Predicted (AFA } \\
\text { miscible)/Avg.Measure }\end{array}$ & - & 5.8 & - & 11.7 & - & 19.9 & - \\
\hline $\begin{array}{l}\text { Ratio: Predicted (AFA } \\
\text { immiscible)/Avg.Measure }\end{array}$ & - & 4.9 & - & 1.0 & - & 2.1 & - \\
\hline
\end{tabular}

${ }^{\$}$ From Appendix C, Predicted HGR Rad/Therm (AFA miscible) $=\mathrm{HGR}_{\mathrm{LAW} 0}+\mathrm{HGR}_{-}$imi $_{\mathrm{AFA} 0}+\mathrm{HGR}_{\mathrm{AFA} 0}$

${ }^{\$ s}$ From Appendix C, Predicted HGR Rad/Therm (AFA immiscible) $=\mathrm{HGR}_{\mathrm{LAW} 0}+\mathrm{HGR}_{-} \mathrm{imi}_{\mathrm{AFA} 0}$ 
WSRC-TR-2005-00281, REVISION 0

SRNL-RPP-2005-00040, REVISION 0

\subsection{SUMMARY OF DATA AND DISCUSSION}

The data presented in Table 3-9 and Table 3-11 can be summarized into a single collection for comparison. Table 3-12 shows all of the data from the radiolysis and thermolysis combination testing. The HGRs shown in Table 3-12 are arranged in decreasing order for the various systems studied in this radiolysis/thermolysis testing. Systems that used replicate samples showed \%RSD values in the range of 4 to $24 \%$. The predicted HGR/measured HGR column shows that in all cases where antifoam is present, the predicted HGRs are bounding for the measured HGRs. The predicted and measured HGRs are in good agreement (predictied to measured ratios in range of 0.9 to 2.1) for both the high and low antifoamcontaining base simulant when the antifoam is treated as immiscible. If one assumes the antifoam to be completely miscible in the HGR correlation, predicted HGRs are considerably higher than measured values, with predicted HGRs about 10 to 20 times the measured values.

Table 3-12. Summary of Data

\begin{tabular}{|c|c|c|c|c|c|}
\hline $\begin{array}{l}\text { Radiolysis and } \\
\text { Thermolysis } \\
\end{array}$ & Avg. HGR & St. Dev. & \% RSD & $\begin{array}{c}\text { Predicted } \\
\text { HGR/Measured } \\
\text { HGR } \\
\end{array}$ & $\begin{array}{c}\text { Antifoam Predicted } \\
\text { (Miscible or } \\
\text { Immiscible) } \\
\end{array}$ \\
\hline Simulant & (g-mol/kg/day) & (g-mol/kg/day) & & & \\
\hline $\begin{array}{l}\text { Base Simulant, High } \\
\text { Antifoam * }\end{array}$ & $1.2 \mathrm{E}-03$ & $1.8 \mathrm{E}-04$ & 16 & 11.1 & Miscible \\
\hline & & & & 0.9 & Immiscible \\
\hline $\begin{array}{l}\text { Native Simulant, No } \\
\text { Antifoam }\end{array}$ & 8.2E-04 & & & 5.6 & NA*** \\
\hline $\begin{array}{l}\text { AN-107 Simulant, } 0.5 \mathrm{wt} \% \\
\text { Antifoam }\end{array}$ & $6.5 \mathrm{E}-04$ & $2.6 \mathrm{E}-05$ & 4 & 5.8 & Miscible \\
\hline & & & & 4.9 & Immiscible \\
\hline Base Simulant, No Antifoam & $3.2 \mathrm{E}-04$ & & & 0.5 & NA*** \\
\hline \begin{tabular}{|l|} 
Base Simulant, Low \\
Antifoam $* *$
\end{tabular} & $2.1 \mathrm{E}-04$ & $5.0 \mathrm{E}-05$ & 24 & 14.3 & Miscible \\
\hline & & & & 1.5 & Immiscible \\
\hline
\end{tabular}

$*$ High antifoam $=9.5 \mathrm{wt} \%$ AFA, or $4 \mathrm{wt} \%$ TOC-AFA

$* *$ Low antifoam $=2.5 \mathrm{wt} \%$ AFA, or $1 \mathrm{wt} \%$ TOC-AFA

$* * *$ No antifoam added to these simulants 
The WTP HGR correlation is summarized in the Text Box shown in Appendix C. It predicts HGRs to within \pm 3 (Sherwood and Stock 2004). The correlation is applicable for HGRs from $1 \mathrm{E}-07 \mathrm{~g}-\mathrm{mol} / \mathrm{kg} /$ day up to $1 \mathrm{E}-2 \mathrm{~g}-\mathrm{mol} / \mathrm{kg} /$ day. In general the correlation terms can be summarized as follows.

\section{Radiolytic Hydrogen:}

Water radiolysis $=\mathrm{f}($ nitrate, nitrite, dose $)$

TOC radiolysis $=\mathrm{f}(\mathrm{TOC}$, Temperature, reactivity coefficient $)$

Antifoam immiscible radiolysis $=\mathrm{f}($ immiscible fraction AFA, dose $)$

\section{Thermal Hydrogen Production:}

TOC thermolysis $=\mathrm{f}(\mathrm{TOC}$, Temp., liquid fraction, reactivity coefficient, $\mathrm{Al})$

The TOC terms represent the liquid fraction of TOC deriving from either native organic species or from antifoam. Note that there is no thermal hydrogen production term for immiscible antifoam TOC.

An example WTP HGR correlation prediction for antifoam agent addition used in an engineering calculation is also given in Appendix $\mathrm{C}$ for the $\mathrm{AN}-107$ simulant, the native simulant filtrate and the base simulant filtrate containing high and low additions of antifoam. The HGR predictions for the base simulant (with no added antifoam) can also be obtained from the base simulant containing antifoam by neglecting all of the AFA and TOC terms.

\subsection{SAVANNAH RIVER SITE EXPERIENCE WITH ANTIFOAM AGENTS}

Various antifoam agents are currently in use at the Savannah River Site (SRS). The main two areas of use are in the SRS Tank Farms with the Evaporators and at the SRS Defense Waste Processing Facility (DWPF). Three different antifoam agents developed by Dow Corning are identified with use in the SRS evaporators (Swingle 1999). The three antifoam agents are DC AF H-10 Emulsion and DC AF B Emulsion and DC 544 AF. The two emulsion antifoams contain about 10\% PDMS. The DC 544 AF contains about 28\% PDMS and $38 \%$ of a polydimethylsiloxane copolymer. Swingle and White indicate that none of the antifoam agents or their potential degradation products are expected to contribute to the composite lower flammability limit (CLFL) for the waste tanks and evaporators due to the limited quantities and the significant dilution in the tank farm equipment. 
Antifoam agents used in the DWPF include the DC 544 from about 1996 to 2001 during initial operations. A newer antifoam agent was later developed because the DC 544 antifoam agent was not sufficiently effective. The newer antifoam agent is IIT747 developed by the Illinois Institute of Technology (Koopman 1999). Various technical reports from SRNL have investigated the use of these two antifoams in the DWPF processes (Daniel 1999, Lambert 2000, Koopman 2001, Fellinger 2002). Studies have focused on the effectiveness of the antifoam agent to reduce foaming in the DWPF process cells and any radiolytic or thermal decomposition of the antifoam agents to produce hydrogen during sludge processing has not been specifically studied. Hydrogen generation in the Sludge Receipt and Adjustment Tank (SRAT) and Slurry Mix Evaporator (SME) is attributed mainly to radiolytic decomposition of water and transition metal catalyzed decomposition of formic acid used in the SRAT process (Fellinger 2002, Crawford 1995). A typical current IIT747 antifoam addition strategy for the main two DWPF processes are about 800 ppm addition before boiling in the SRAT with about 100 ppm added every 8 hours at boiling. Contents of the SRAT are passed on to the SME where $100 \mathrm{ppm}$ antifoam agent is added before boiling, with 100 ppm added every 8 hours at boiling. Contents of the SME are fed to the Melter Feed Tank (MFT) and then to the DWPF melter.

One particular study involved testing unirradiated vs. irradiated IIT747 antifoam agent in the DWPF simulated sludge processing (Lambert 2000). Conclusions from that study suggest that unirradiated and irradiated antifoam are equally effective. The IIT747 antifoam was irradiated at a dose rate of $2 \times 10^{3} \mathrm{rad} / \mathrm{hr}$ for a 14 day equivalent SRAT/SME cycle of $6.8 \times 10^{5}$ rads. The study also analyzed for silicon-containing antifoam decomposition products in the condensates generated during processing. No differences were determined for silicon analyses from the nonirradiated and irradiated antifoam used during processing, suggesting that no significant steam stripping of any silicon-containing radiation degradation fragments were concentrated in the condensate. 


\subsection{ANTIFOAM DEGRADATION ANALYSES AND RADIOLYTIC DECOMPOSITION SCHEMES}

\subsection{ANTIFOAM DEGRADATION ANALYSES}

Samples of the base simulant filtrate solution with added antifoam were analyzed by DOW Corning personnel. Table 4-1 shows the samples that were shipped to DOW. Each vessel sample \# gives the details of each particular sample. The key to the sample labels is as follows:

TW-vessel number- wt $\%$ AFA, sample-type- analysis

Where

$\mathrm{TW}=$ Tom White (SRNL research personnel)

Vessel number $=$ sample vessel number ID

$\mathrm{Wt} \% \mathrm{AFA}=4$ or $10 \mathrm{wt} \%$ (for labeling purposes only, see last column of Table 4-1

for actual $w t \%$ Antifoam values)

Sample type $=$ 'S' for irradiated/heated sample, 'STD' for standard, 'B' for blank

Analysis = PDMS for polydimethylsiloxane and PPG for polypropyleneglycol

All four of the ' $\mathrm{S}$ ' type samples were from radiolysis/thermolysis testing. These four samples had been exposed to 12 days dose at dose rate of $1.8 \mathrm{E} 5 \mathrm{rad} / \mathrm{hr}$, or a total of $5.2 \mathrm{E} 7 \mathrm{rad}$ (52 Mrad). The samples had also been exposed to 23 days of $90^{\circ} \mathrm{C}$ (from combined radiolysis/thermolysis 12-day testing, followed by additional 11-day thermolysis-only testing). All of the 'STD' samples were prepared with antifoam added to base simulant filtrate shortly before shipment to DOW for analyses. The 'B' blank systems were base simulant filtrate containing no antifoam. Neat samples of the actual Q2-3183A antifoam 'controls' used in this study were also analyzed by DOW Corning. These control samples were prepared by Dow Corning personnel from the same batch of Q2-3183A antifoam used for the SRNL testing. The control samples used 10,000 ppm w/v of antifoam added to either tetrahydrofuran or toluene. These concentrations are shown as 1.12 and $1.15 \mathrm{wt} \%$ in Table 4-1.

The control samples were analyzed and the amounts of PDMS and PPG detected were set at $100 \%$ recovery. All simulant samples were extracted and analyzed for either PDMS or PPG by gel-permeation chromatography (GPC) by DOW Corning personnel. Results of the PDMS analyses in the toluene extracts and the PPG analyses in the THF extracts are given in the 'Analytical Solutions Report' from DOW Corning. All results in this report are given as '\% recovery' or as 'percent of polymer remaining'. All data from extraction of the antifoam components in simulant are referenced to the control samples. Details of the extraction procedures are also given below in the Experimental Section of the 'Analytical Solutions Report' from DOW Corning. Standard curves were also generated for the two solvent systems by using polystyrene standards in either the toluene or THF solvents. These standard curves are shown as Figure 4-1 and Figure 4-2, respectively. 
The key findings from the PDMS analyses (see Table labeled 'PDMS results (toluene)' from the Analytical Solutions Report from Dow Corning) were that the PDMS appeared to be completely absent in the $4 \mathrm{~S}$ and $10 \mathrm{~S}$ samples. Also there was excellent precision in PDMS analysis of the triplicate $4 \mathrm{wt} \%$ AFA standards (vessels 71,73 and 76 show $76 \%$ to $79 \%$ recovery). There appears to be a discrepancy in the recovery of the $4 \mathrm{wt} \%$ AFA samples (actual $\sim 2.5 \mathrm{wt} \%$ antifoam) and the $10 \mathrm{wt} \%$ AFA samples (actual $\sim 9.5 \mathrm{wt} \%$ antifoam) vs. the control samples of $\sim 1 \mathrm{wt} \%$ antifoam. Only $\sim 80 \%$ recovery was realized for the simulants labeled $4 \mathrm{wt} \%$ antifoam vs. $120 \%$ recover from the simulants labeled $10 \mathrm{wt} \%$ antifoam. These recoveries were referenced to analysis of the control sample of pure antifoam at $\sim 1 \mathrm{wt} \%$.

The PPG analyses indicate that the 4S and 10S samples show a broadening of the PPG peak relative to the control sample. The PPG peak is the main peak eluting from about $15.5-$ 17 minutes in the 'THF/RI' plots in the Dow report. The Dow report 'PPG results (THF)' table on pg. 2 of 5 actually indicates $>100 \%$ recovery for the $4 \mathrm{~S}$ and $10 \mathrm{~S}$ samples using peak area analyses. However if these peaks are analyzed by reduction in peak height, the results show that at least $60 \%$ of the original antifoam PPG component has degraded for these samples. Both the PDMS and PPG tables showing analyses for reduction in peak height are shown below in Table 4-2. Peak height reduction analyses for PPG indicates that only $21 \%$ of the PPG remained for the 4S-PPG sample and only $39 \%$ of the PPG remained for the $10 \mathrm{~S}$ PPG sample. In other words $61-79 \%$ of the original PPG component is destroyed. Peak height information for PDMS in Table 4-2 shows that $0 \%$ of the PDMS remaind for both the 4S-PDMS and the 10S-PDMS samples.

These data for current testing show complete destruction of the PDMS and $61-79 \%$ destruction of PPG at 5.2E7 rad absorbed dose for these samples that had initial amounts of antifoam in the range of 2.5 to $9.5 \mathrm{wt} \%$. These data are in agreement with earlier results reported for irradiation studies on $\sim 1.4 \mathrm{wt} \%$ Q2-3182A antifoam in a concentrated blend of UF1B/VSL SBS simulant (Baich et al. 2003). Earlier work used three different doses of 8-hr $(1.5 \mathrm{E} 6 \mathrm{rad}), 2$-day $(9.3 \mathrm{E} 6 \mathrm{rad})$ and $7 \mathrm{~d}(3.2 \mathrm{E} 7 \mathrm{rad})$. Conclusions from that work indicated that the 7-day dose of $3.2 \mathrm{E} 7$ rads destroyed the majority of the $1.4 \mathrm{wt} \%$ original antifoam in the simulant.

\subsection{RADIOLYTIC DECOMPOSITION SCHEMES}

Initial steps of radiolytic degradation schemes of the main antifoam constituents PDMS and PPG are illustrated in Figure 4-3 and Figure 4-4. Figure 4-3 shows the PDMS polymer undergoing loss of $\mathrm{H}$ or $\mathrm{CH}_{3}$ radicals from the PDMS structure (Products 1 and $\mathrm{H}$ and Products 2 and $\mathrm{CH}_{3}$ ). These radicals are the precursors to the known radiolytic decomposition products of PDMS of hydrogen, methane and ethane (Spinks and Woods 1990; Chapiro 1962). Another pathway is direct bond breakage of the parent polymer to decompose the polymer into smaller chain molecules of Products 3 and 4. This mechanism is common in radiolytic polymer degradation and leads to a reduction in average molecular weight caused by the main-chain scission (Spinks and Woods 1990). 
Similar radiolytic decomposition schemes for the other Q2-3183A antifoam polymer (PPG) are shown in Figure 4-4 . The initial radiolytic decay schemes shown in Figure 4-3 and Figure 4-4 are presented only to indicate possible pathways for hydrogen production. A more detailed report investigating the detailed degradation of these Q2-3183A antifoam polymer components is currently in progress at SRNL (Burket 2005b), and results will be reported at a later time.

Other degradative reactions of silicones involving thermal, hydrolytic, photostability and oxidative pathways have been discussed in detail by Brook (2000). For instance, silicones that are simultaneously exposed to irradiation and oxygen can breakdown via carbon oxidation and $\mathrm{Si}-\mathrm{C}$ bond cleavage to give ultimate end-products of $\mathrm{CO}_{2}, \mathrm{H}_{2} \mathrm{CO}$ and $\mathrm{SiO}_{2}(\mathrm{See}$ Chapter 9 in Brook 2000). Certain volatile siloxane decomposition products (organosilicon compounds) such as hexamethylcyclotrisiloxane $\left(\left[\left(-\mathrm{CH}_{3}\right)_{2} \mathrm{SiO}-\right)_{3}\right]$ and oxtamethylcyclotetrasiloxane $\left(\left[\left(-\mathrm{CH}_{3}\right)_{2} \mathrm{SiO}-\right)_{4}\right]$ have also been reported.

The radiolytic reduction in PDMS average molecular weight can be seen in the Dow Corning report figures labeled 'Toluene/RI' for both the $4 \mathrm{wt} \%$ and the $10 \mathrm{wt} \%$ antifoam samples on page indicated as 'Page 4 of 5 '. The irradiated $4 \mathrm{wt} \%$ antifoam sample (TW59-4S-PDMS) shown as the lower curve in the first Toluene/RI figure shows near complete loss at the higher molecular weight range of 10 - 17 minutes and lowering of peak area in the lower molecular weight range corresponding to the proposed PPG peak at 17-19 minutes. These data are interpreted to indicate a general reduction in the molecular weight of the PDMS and the PPG components of the antifoam. Similar conclusions can be drawn from the $10 \mathrm{wt} \%$ antifoam sample shown as the next-to lowest curve in the second 'Toluene/RI' figure.

The radiolytic decomposition schemes shown in Figure 4-3 and Figure 4-4 represent direct interaction of ionizing radiation with the polymers. These type reactions would be relevant for the immiscible AFA components in the simulant solutions. Other reaction schemes involving indirect radiolytic decomposition of miscible AFA organic components, which would be homogeneously mixed throughout the simulant solution, involve primary solvent (water) radiolysis, followed by attack of the miscible polymers by the reactive primary radicals formed from water radiolysis, i.e., $\mathrm{OH}$, hydrated electron $\left(\mathrm{e}_{\mathrm{aq}}{ }^{-}\right)$and $\mathrm{H}$. For instance, Table 8.2 'Generic Radiolysis Mechanism for Organic Solutes in Aqueous Solutions' from Spinks (1990) gives a summary of these types of reactions. Using $\mathrm{RH}_{2}$ to represent the possible miscible AFA organic components (PDMS or PPG), the following reaction could account for hydrogen production from indirect radiolysis of the miscible antifoam components.

$$
\mathrm{H}^{\cdot} \text { (from direct water radiolysis) }+\mathrm{RH}_{2} \rightarrow \mathrm{H}_{2}+\mathrm{RH} \cdot
$$


WSRC-TR-2005-00281, REVISION 0

SRNL-RPP-2005-00040, REVISION 0

Table 4-1. Summary of Analyses Performed by Dow Corning for SRNL

\begin{tabular}{|c|c|c|c|c|c|c|c|}
\hline \multicolumn{5}{|l|}{ GPC Analyses } & \multirow[b]{2}{*}{$\begin{array}{l}\text { Simulant } \\
\text { (g) }\end{array}$} & \multirow[b]{2}{*}{$\begin{array}{c}\text { Antifoam } \\
\text { (g) }\end{array}$} & \multirow[b]{2}{*}{$\begin{array}{c}\text { Actual } \\
\text { wt\% } \\
\text { Antifoam } \\
\end{array}$} \\
\hline Sample \# & Vessel \# & $\begin{array}{l}\text { Vol., } \\
\text { mL }\end{array}$ & Description* & Analysis & & & \\
\hline $\begin{array}{c}\text { TW-57-10S- } \\
\text { PDMS }\end{array}$ & 57 & 15 & $\begin{array}{c}10 \mathrm{wt} \% \text { Q2- } \\
3183 \mathrm{~A} \text { Sample }\end{array}$ & GPC for PDMS & 16.9430 & 1.7921 & 9.57 \\
\hline $\begin{array}{c}\text { TW-58-10S- } \\
\text { PPG }\end{array}$ & 58 & 15 & $\begin{array}{c}10 \mathrm{wt} \% \text { Q2- } \\
3183 \text { A Sample }\end{array}$ & GPC for $P P G$ & 16.8433 & 1.7726 & 9.52 \\
\hline $\begin{array}{c}\text { TW-59-4S- } \\
\text { PDMS }\end{array}$ & 59 & 15 & $\begin{array}{c}4 \mathrm{wt} \% \text { Q2- } \\
3183 \mathrm{~A} \text { Sample }\end{array}$ & GPC for PDMS & 18.2713 & 0.4917 & 2.62 \\
\hline TW-60-4S-PPG & 60 & 15 & $\begin{array}{c}4 \mathrm{wt}^{\circ} \% \mathrm{Q} 2- \\
\text { 3183A Sample }\end{array}$ & GPC for PPG & 18.3272 & 0.4684 & 2.49 \\
\hline $\begin{array}{c}\text { TW-62-4STD- } \\
\text { PPG }\end{array}$ & 62 & 15 & $\begin{array}{c}4 \mathrm{wt} \% \text { Q2- } \\
\text { 3183A Sample }\end{array}$ & GPC for PPG & 18.4322 & 0.4876 & 2.58 \\
\hline $\begin{array}{c}\text { TW-63-4STD- } \\
\text { PPG }\end{array}$ & 63 & 15 & $\begin{array}{c}4 \mathrm{wt}^{\%} \% \mathrm{Q} 2- \\
\text { 3183A Sample }\end{array}$ & GPC for PPG & 18.3617 & 0.4952 & 2.63 \\
\hline TW-66-B-PPG & 66 & 15 & Blank & GPC for PPG & 19.6931 & 0 & 0.00 \\
\hline $\begin{array}{c}\text { TW-67-4STD- } \\
\text { PPG }\end{array}$ & 67 & 15 & $\begin{array}{c}4 w^{\circ} \% \text { Q2- } \\
\text { 3183A Sample }\end{array}$ & GPC for $P P G$ & 18.3427 & 0.4733 & 2.52 \\
\hline $\begin{array}{c}\text { TW-70-10STD- } \\
\text { PPG }\end{array}$ & 70 & 15 & $\begin{array}{c}10 \mathrm{wt} \% \text { Q2- } \\
3183 \mathrm{~A} \text { Sample }\end{array}$ & GPC for $P P G$ & 16.9532 & 1.7775 & 9.49 \\
\hline $\begin{array}{c}\text { TW-71-4STD- } \\
\text { PDMS }\end{array}$ & 71 & 15 & $\begin{array}{c}4 \mathrm{wt}^{\circ} \% \text { Q2- } \\
\text { 3183A Sample }\end{array}$ & GPC for PDMS & 18.3528 & 0.4660 & 2.48 \\
\hline $\begin{array}{c}\text { TW-73-4STD- } \\
\text { PDMS }\end{array}$ & 73 & 15 & $\begin{array}{c}4 \mathrm{wt} \% \text { Q2- } \\
\text { 3183A Sample }\end{array}$ & GPC for PDMS & 18.4280 & 0.4591 & 2.43 \\
\hline $\begin{array}{l}\text { TW-74-B- } \\
\text { PDMS }\end{array}$ & 74 & 15 & Blank & GPC for PDMS & 19.7353 & 0 & 0.00 \\
\hline $\begin{array}{c}\text { TW-76-4STD- } \\
\text { PDMS }\end{array}$ & 76 & 15 & $\begin{array}{c}4 \mathrm{wt} \% \text { Q2- } \\
\text { 3183A Sample }\end{array}$ & GPC for PDMS & 18.3846 & 0.4733 & 2.51 \\
\hline $\begin{array}{c}\text { TW-78-10STD- } \\
\text { PDMS } \\
\text { Q2-3183A } \\
\text { Control-PPG } \\
\text { Q2-3183A } \\
\text { Control-PDMS }\end{array}$ & $\begin{array}{c}78 \\
(\mathrm{THF})^{* *} \\
\text { (toluene) })^{* * *}\end{array}$ & 15 & $\begin{array}{c}10 \mathrm{wt} \% \text { Q2- } \\
\text { 3183A Sample } \\
\text { Neat Q2-3183A } \\
\text { Neat Q2-3183A }\end{array}$ & $\begin{array}{l}\text { GPC for PDMS } \\
\text { GPC for PPG } \\
\text { GPC for PDMS }\end{array}$ & $\begin{array}{l}17.0815 \\
880 * * \\
860 * * *\end{array}$ & $\begin{array}{c}1.7796 \\
10 \\
10\end{array}$ & $\begin{array}{l}9.44 \\
1.12 \\
1.15\end{array}$ \\
\hline
\end{tabular}

* Sample descriptions use $10 \mathrm{wt} \%$ Q2-3183A and $4 \mathrm{wt} \%$ Q2-3183A for labeling purposes. The actual wt $\%$ antifoam values are calculated and shown in this table in the far right column.

** antifoam directly in tetrahydrofuran (THF) at $10,000 \mathrm{ppm} \mathrm{w} / \mathrm{v}$; density $\mathrm{THF}=0.88 \mathrm{~g} / \mathrm{mL}$

$* * *$ antifoam directly in toluene at $10,000 \mathrm{ppm} \mathrm{w} / \mathrm{v}$; density toluene $=0.86 \mathrm{~g} / \mathrm{mL}$ 
WSRC-TR-2005-00281, REVISION 0

SRNL-RPP-2005-00040, REVISION 0

Table 4-2. Gel Permeation Chromatography with Peak Height

\begin{tabular}{|c|c|c|c|c|c|}
\hline \multicolumn{6}{|c|}{ GPC Analyses by Peak Height } \\
\hline Sample \# & Vessel \# & $\begin{array}{l}\text { Vol., } \\
m L\end{array}$ & Description & $\begin{array}{c}\text { Peak Height, } \\
\mathrm{mV}\end{array}$ & $\begin{array}{l}\text { \% Polymer } \\
\text { Remaining }\end{array}$ \\
\hline \multicolumn{6}{|c|}{ PPG Analyses } \\
\hline $\begin{array}{l}\text { Q2-3183A } \\
\text { Control-PPG }\end{array}$ & & & DC Control & 90.5 & 100 \\
\hline $\begin{array}{l}\text { TW-70-10STD- } \\
\text { PPG }\end{array}$ & 70 & 15 & 10\% Q2-3183A Sample & 100.6 & 111 \\
\hline TW-58-10S-PPG & 58 & 15 & $\begin{array}{l}\text { 10\% Q2-3183A Irradiated } \\
\text { Sample }\end{array}$ & 35.1 & 39 \\
\hline TW-62-4STD-PPG & 62 & 15 & 4\% Q2-3183A Sample & 70.2 & 78 \\
\hline TW-63-4STD-PPG & 63 & 15 & 4\% Q2-3183A Sample & 72.6 & 80 \\
\hline TW-67-4STD-PPG & 67 & 15 & 4\% Q2-3183A Sample & 69.9 & 77 \\
\hline TW-66-B-PPG & 66 & 15 & Blank & 0 & 0 \\
\hline TW-60-4S-PPG & 60 & 15 & $\begin{array}{l}\text { 4\% Q2-3183A Irradiated } \\
\text { Sample }\end{array}$ & 18.8 & 21 \\
\hline \multicolumn{6}{|c|}{ PDMS Analyses } \\
\hline $\begin{array}{l}\text { Q2-3183A } \\
\text { Control-PDMS }\end{array}$ & & & DC Control & 25.4 & 100 \\
\hline $\begin{array}{l}\text { TW-78-10STD- } \\
\text { PDMS }\end{array}$ & 78 & 15 & 10\% Q2-3183A Sample & 30.6 & 120 \\
\hline TW-57-10S-PDMS & 57 & 15 & $\begin{array}{l}\text { 10\% Q2-3183A Irradiated } \\
\text { Sample }\end{array}$ & 0 & 0 \\
\hline $\begin{array}{l}\text { TW-71-4STD- } \\
\text { PDMS }\end{array}$ & 71 & 15 & 4\% Q2-3183A Sample & 20.5 & 81 \\
\hline $\begin{array}{l}\text { TW-73-4STD- } \\
\text { PDMS }\end{array}$ & 73 & 15 & 4\% Q2-3183A Sample & 19.8 & 78 \\
\hline $\begin{array}{l}\text { TW-76-4STD- } \\
\text { PDMS }\end{array}$ & 76 & 15 & 4\% Q2-3183A Sample & 20.3 & 80 \\
\hline TW-74-B-PDMS & 74 & 15 & Blank & 0 & 0 \\
\hline TW-59-4S-PDMS & 59 & 15 & $\begin{array}{l}\text { 4\% Q2-3183A Irradiated } \\
\text { Sample }\end{array}$ & 0 & 0 \\
\hline
\end{tabular}


WSRC-TR-2005-00281, REVISION 0

SRNL-RPP-2005-00040, REVISION 0

DOW CORNING

\section{Analytical Solutions Report}

Customer Confidential ISO9001:2000 Registered

\begin{tabular}{|ll|}
\hline Customer: & Westinghouse River Savannah Company \\
Contact: & Tom White \\
E-Mail: & thomas02.white@sml.doe.gov \\
Phone: & 803-725-1963 \\
Quote Reference: & Q2-3183A.xls \\
\hline
\end{tabular}

\begin{tabular}{|ll|}
\hline Report: & External \\
Report Number: & 24125 \\
Sample Receipt Date: & $5 / 26 / 2005$ \\
Report Sent Date: & $6 / 09 / 2005$ \\
Customer Reference: & AC37127T \\
\hline
\end{tabular}

Description of Request:

Analyze molecular weight of PPG and PDMS in Q2-3183A for signs of degradation by GPC in radiated caustic salt mixture.

Samples Identifier:

\begin{tabular}{|l|c|c|l|l|}
\hline \multicolumn{1}{|c|}{ Sample \# } & Vessel \# & Vol,, $\boldsymbol{m L}$ & \multicolumn{1}{c|}{ Description } & \multicolumn{1}{c|}{ Analysis } \\
\hline \hline TW-57-10S-PDMS & 57 & 15 & $10 \%$ Q2-3183A Sample & GPC for PDMS \\
\hline TW-58-10S-PPG & 58 & 15 & $10 \%$ Q2-3183A Sample & GPC for PPG \\
\hline TW-59-4S-PDMS & 59 & 15 & $4 \%$ Q2-3183A Sample & GPC for PDMS \\
\hline TW-60-4S-PPG & 60 & 15 & $4 \%$ Q2-3183A Sample & GPC for PPG \\
\hline TW-62-4STD-PPG & 62 & 15 & $4 \%$ Q2-3183A Sample & GPC for PPG \\
\hline TW-63-4STD-PPG & 63 & 15 & $4 \%$ Q2-3183A Sample & GPC for PPG \\
\hline TW-66-B-PPG & 66 & 15 & Blank & GPC for PPG \\
\hline TW-67-4STD-PPG & 67 & 15 & $4 \%$ Q2-3183A Sample & GPC for PPG \\
\hline TW-70-10STD-PPG & 70 & 15 & $10 \%$ Q2-3183A Sample & GPC for PPG \\
\hline TW-71-4STD-PDMS & 71 & 15 & $4 \%$ Q2-3183A Sample & GPC for PDMS \\
\hline TW-73-4STD-PDMS & 73 & 15 & $4 \%$ Q2-3183A Sample & GPC for PDMS \\
\hline TW-74-B-PDMS & 74 & 15 & Blank & GPC for PDMS \\
\hline TW-76-4STD-PDMS & 76 & 15 & $4 \%$ Q2-3183A Sample & GPC for PDMS \\
\hline TW-78-10STD-PDMS & 78 & 15 & $10 \%$ Q2-3183A Sample & GPC for PDMS \\
\hline
\end{tabular}

Results*:

PDMS analyses

The GPC analyses of the "PDMS" samples were conducted with toluene as the eluent and using refractive index detection. The chromatogram of the control sample consisted of a bimodal distribution, with the higher molecular weight peak (10-17 minutes) being the PDMS peak of interest. The lower molecular weight peak (17-19 minutes) is presumably the PPG, which was somewhat broad and appeared to hang onto the columns to some degree. This is likely an artifact of its relatively polar nature compared to toluene. Only the PDMS peak was evaluated for these analyses due to the poor peak shape of the PPG peak. The chromatograms for the STD samples all looked fairly similar to the control sample, with the addition of a low molecular weight shoulder on the PPG peak that was not seen in the control. It was a little unexpected that the PPG appeared to partition completely into the toluene phase and not the water phase. The molecular weight of the PDMS peak in the STD samples was unchanged relative to the control sample. The 4STD samples all had less PDMS recovered than theoretical and the 10STD sample had more PDMS recovered than theoretical. The PDMS appeared to be completely absent in the $4 \mathrm{~S}$ and $10 \mathrm{~S}$ samples. It is possible that some (though clearly not all) of the siloxane has reverted to cyclics, but they would not be definitively seen in these analyses due to the overlap of the PPG peak. 
WSRC-TR-2005-00281, REVISION 0 SRNL-RPP-2005-00040, REVISION 0

The following molecular weight averages are relative to polystyrene standards and are for the PDMS peak only. The \% recovery values are based on a one-point calibration using the results from the control sample, and assume complete transfer of the PDMS into the toluene phase and complete separation of the toluene and water phases.

\begin{tabular}{|c|c|c|c|c|c|c|}
\hline \multicolumn{7}{|c|}{ PDMS results (toluene) } \\
\hline Sample Name & $\mathrm{Mp}$ & $\mathrm{Mn}$ & Mw & Mz & PD & $\%$ recovery \\
\hline TW-74-B-PDMS & \multicolumn{5}{|c|}{ no significant amount of PDMS detected } & $0 \%$ \\
\hline TW-71-4STD-PDMS & 31700 & 16500 & 35500 & 62900 & 2.15 & $79 \%$ \\
\hline TW-73-4STD-PDMS & 30900 & 16300 & 35600 & 65300 & 2.18 & $76 \%$ \\
\hline TW-76-4STD-PDMS & 32000 & 16100 & 35100 & 62900 & 2.18 & $78 \%$ \\
\hline TW-59-4S-PDMS & \multicolumn{5}{|c|}{ no significant amount of PDMS detected } & $0 \%$ \\
\hline TW-78-10STD-PDMS & 31200 & 16200 & 36100 & 67700 & 2.23 & $120 \%$ \\
\hline TW-57-10S-PDMS & \multicolumn{5}{|c|}{ no significant amount of PDMS detected } & $0 \%$ \\
\hline Q2-3183A control & 30900 & 14800 & 34700 & 64400 & 2.34 & $100 \%$ \\
\hline
\end{tabular}

\section{$P P G$ analyses}

The GPC analyses of the "PPG" samples were conducted with THF as the eluent and using refractive index detection. The chromatogram of the control sample consisted of three distinct areas. The main peak eluting from about $15.5-17$ minutes would correspond to the PPG. The lower molecular weight peak eluting from about 17-18.5 is assumed to be the (t-octyl phenoxy) polyethoxyethanol component of the sample, but has not been verified. The higher molecular weight material eluting from about 12-15.5 minutes would correspond to the PDMS portion of the sample, which has a poor response under these analysis conditions. The chromatograms for the STD samples all looked fairly similar to the chromatogram of the control sample. The molecular weight of the PPG peak in the STD samples was unchanged relative to the control sample. The 4STD samples all had less PPG recovered than theoretical and the 10 STD sample had more PPG recovered than theoretical. The PPG peak in the GPC chromatograms for the $4 \mathrm{~S}$ and $10 \mathrm{~S}$ samples appears to have broadened relative to the control sample, especially in the $10 \mathrm{~S}$ sample.

An unexpected observation of the PPG analyses was that the THF and water separated into two distinct phases for all of these samples, including the blank. THF and water are normally completely miscible, so the separation must be an artifact of some component of the samples.

The following molecular weight averages are relative to polystyrene standards and were determined for the PPG (peak \#1) and lower molecular weight (peak \#2) peaks separately. The \% recovery values are based on a one-point calibration using the results from the control sample, and assume complete transfer of the components into the THF phase and complete separation of the THF and water phases.

\begin{tabular}{|c|c|c|c|c|c|c|c|}
\hline \multicolumn{8}{|c|}{ PPG results (THF) } \\
\hline Sample Name & Peak \# & $\mathrm{Mp}$ & $\mathrm{Mn}$ & $\mathrm{Mw}$ & $\mathrm{Mz}$ & PD & $\%$ recovery \\
\hline TW-66-B-PPG & \multicolumn{7}{|c|}{ no significant amount of PPG detected } \\
\hline & & & & & & & \\
\hline TW-62-4STD-PPG & 1 & 3360 & 3300 & 3570 & 3900 & 1.08 & $81 \%$ \\
\hline TW-62-4STD-PPG & 2 & 843 & 756 & 841 & 923 & 1.11 & $88 \%$ \\
\hline TW-63-4STD-PPG & 1 & 3350 & 3290 & 3550 & 3880 & 1.08 & $83 \%$ \\
\hline TW-63-4STD-PPG & 2 & 834 & 761 & 840 & 919 & 1.10 & $87 \%$ \\
\hline TW-67-4STD-PPG & 1 & 3340 & 3280 & 3540 & 3850 & 1.08 & $80 \%$ \\
\hline TW-67-4STD-PPG & 2 & 829 & 761 & 836 & 911 & 1.10 & $82 \%$ \\
\hline TW-60-4S-PPG & 1 & 2920 & 2510 & 3440 & 5140 & 1.37 & $50 \%$ \\
\hline TW-60-4S-PPG & 2 & 932 & 680 & 753 & 818 & 1.11 & $102 \%$ \\
\hline
\end{tabular}


WSRC-TR-2005-00281, REVISION 0

SRNL-RPP-2005-00040, REVISION 0

Dow Corning Analytical Solutions

Customer Confidential

\begin{tabular}{|c|c|c|c|c|c|c|c|}
\hline Sample Name & Peak\# & $\mathrm{Mp}$ & $\mathrm{Mn}$ & Mw & Mz & PD & $\%$ recovery \\
\hline TW-70-10STD-PPG & 1 & 3280 & 3230 & 3490 & 3810 & 1.08 & $116 \%$ \\
\hline TW-70-10STD-PPG & 2 & 829 & 757 & 829 & 900 & 1.10 & $115 \%$ \\
\hline TW-58-10S-PPG & 1 & 3100 & 3070 & 4960 & 8800 & 1.62 & $106 \%$ \\
\hline TW-58-10S-PPG & 2 & 1077 & 692 & 778 & 852 & 1.12 & $155 \%$ \\
\hline Q2-3183A control & 1 & 3310 & 3230 & 3450 & 3720 & 1.07 & $100 \%$ \\
\hline Q2-3183A control & 2 & 829 & 761 & 832 & 902 & 1.09 & $100 \%$ \\
\hline
\end{tabular}

The samples chromatograms are at the end of this report.

\section{Experimental:}

The sample tubes were all emptied into individual $4 \mathrm{oz}$ bottles and then rinsed with a number of solvent rinses. The PDMS sample tubes were rinsed with two $10 \mathrm{~mL}$ water rinses and four $15 \mathrm{~mL}$ toluene rinses. The PPG sample tubes were rinsed with three $15 \mathrm{~mL}$ THF rinses. For each rinse, the sealed tube was shaken about one minute and allowed to set for 15-30 minutes before emptying into their corresponding collection vessel. The inside of the sample tubes were briefly scraped with a spatula before the first rinse in order to remove the majority of the solids from the inside of the tubes. After the rinses were complete, a small amount of solid on the inside wall of several vessels was observed, but it was assumed that the majority of the soluble polymer would have been removed in the rinsing. The collection vessels containing the initial samples and the solvent rinses were shaken on a wrist shaker for one hour and then allowed to settle for about two hours, at which time the samples had all separated into two layers.

GPC analyses were conducted on the samples using either tetrahydrofuran or toluene as eluents, PS/DVB size exclusion columns $(2,000,000 \mathrm{MW}$ maximum), a differential refractive index detector, and a relative polystyrene calibration curve for calculation of molecular weight averages.

\section{Statement of Accuracy and Precision:}

The precision and accuracy for this analysis have not been established. In general, the repeatability for other polymers analyzed in a similar manner by GPC is $\pm 5-10 \%$ (relative).

* Note, results relate only to the items submitted for analysis. 
WSRC-TR-2005-00281, REVISION 0

SRNL-RPP-2005-00040, REVISION 0
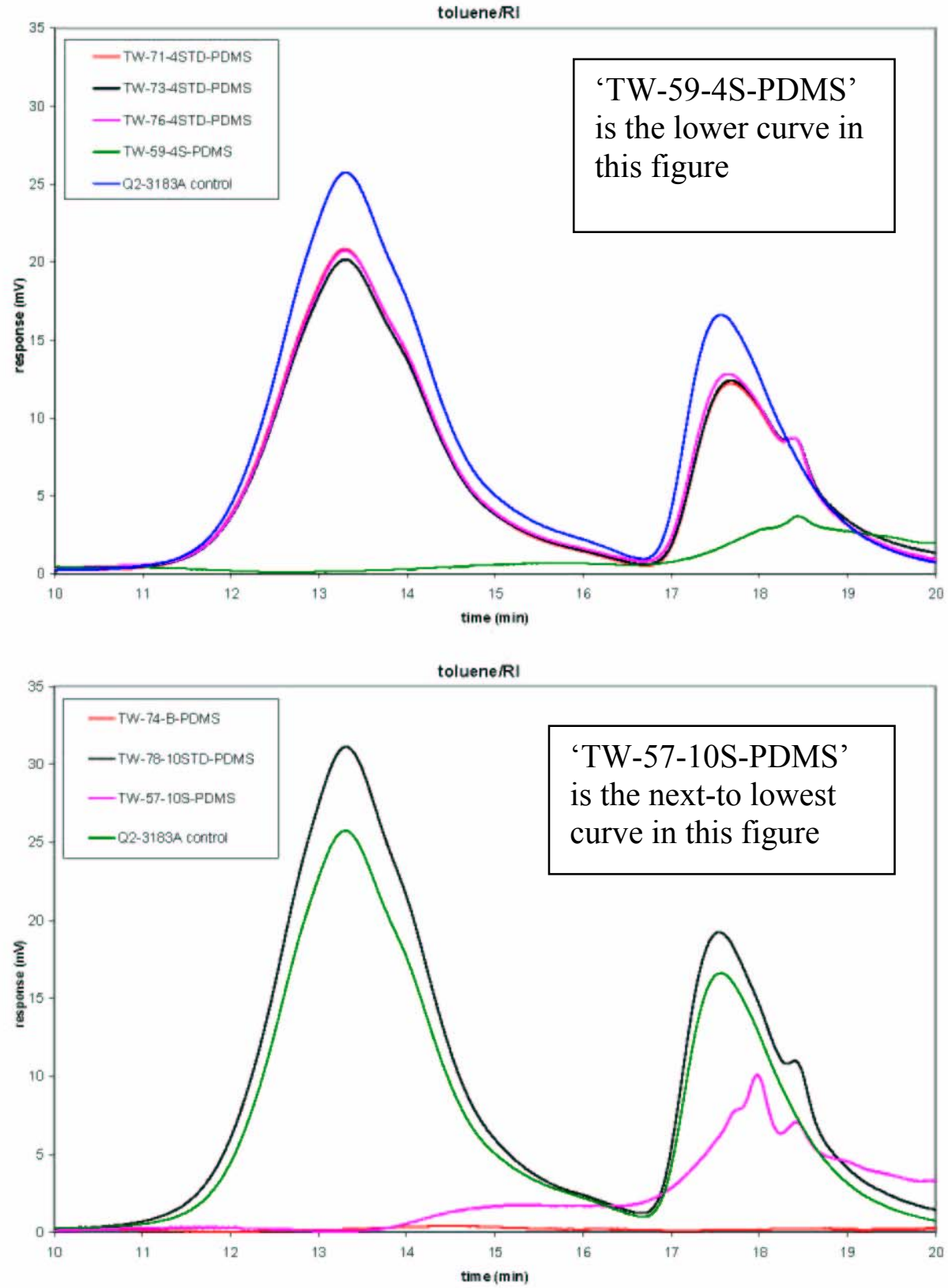

Page 4 of 5

Visit us at http://www.dowcorning.com/analytical 
WSRC-TR-2005-00281, REVISION 0

SRNL-RPP-2005-00040, REVISION 0

Dow Corning Analytical Solutions

Customer Confidential ISO9001:2000 Registered


Page 5 of 5

Visit us at http://www.dowcorning.com/analytical 
$\log M=14.36-1.277 \mathrm{X}^{1}+0.05699 \mathrm{X}^{2}-0.00126 \mathrm{X}^{3}$ (toluene)

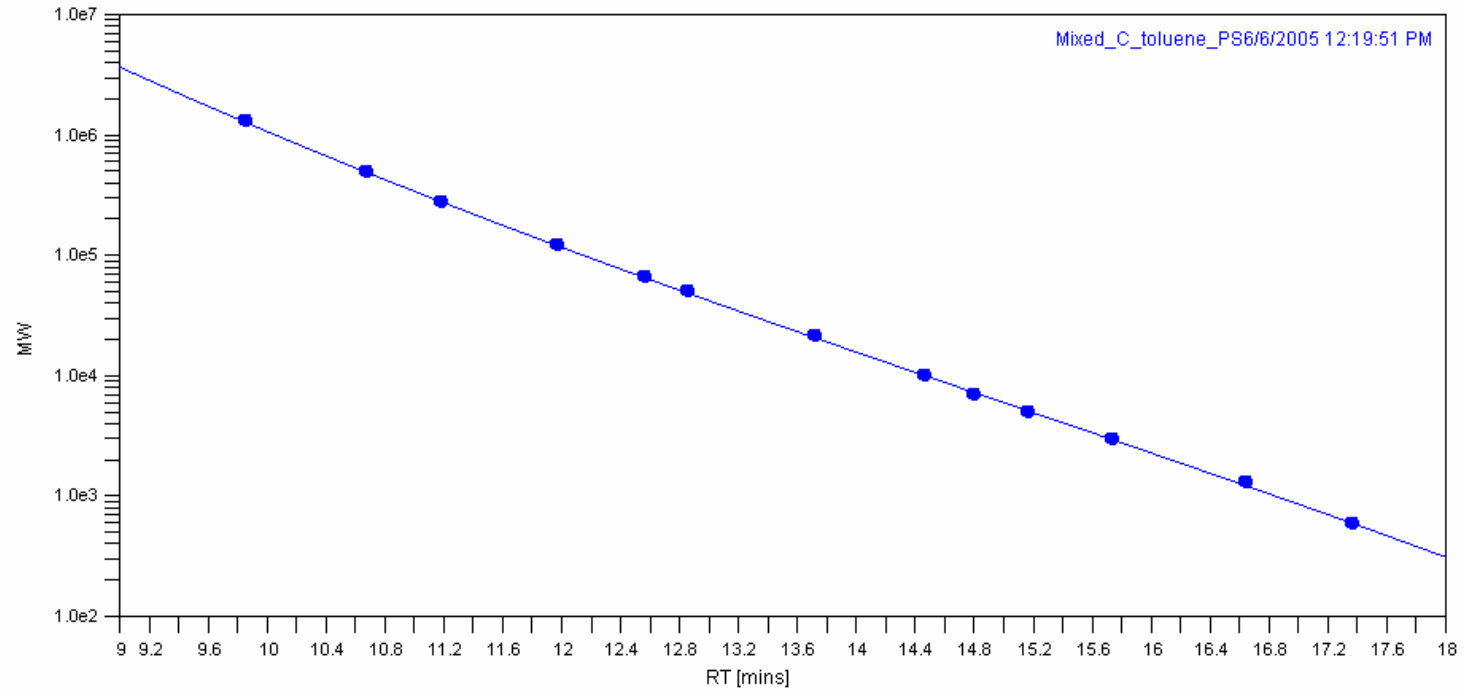

Figure 4-1. Standard Curve for Molecular Weights vs. Retention Time for Polystyrene in Toluene

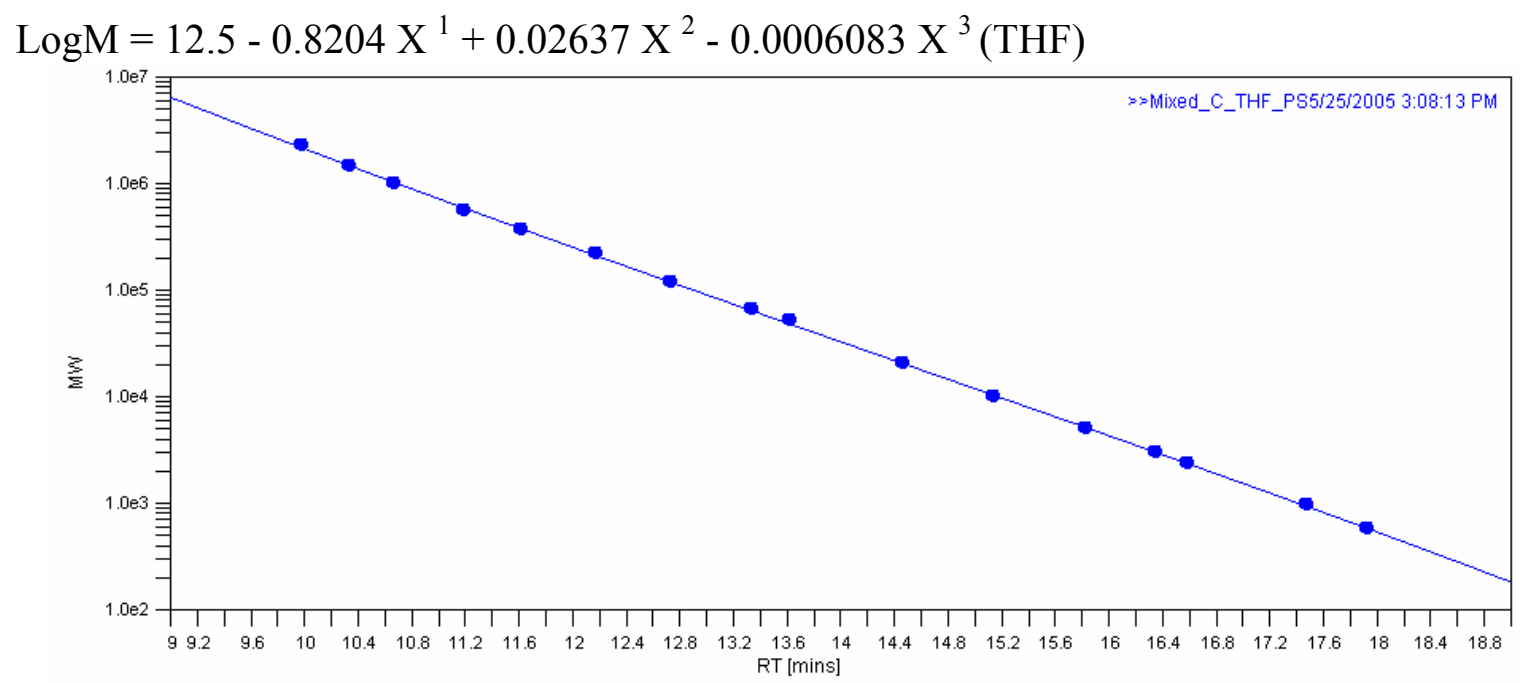

Figure 4-2. Standard Curve for Molecular Weights vs. Retention Time for Polystyrene in THF 
WSRC-TR-2005-00281, REVISION 0

SRNL-RPP-2005-00040, REVISION 0

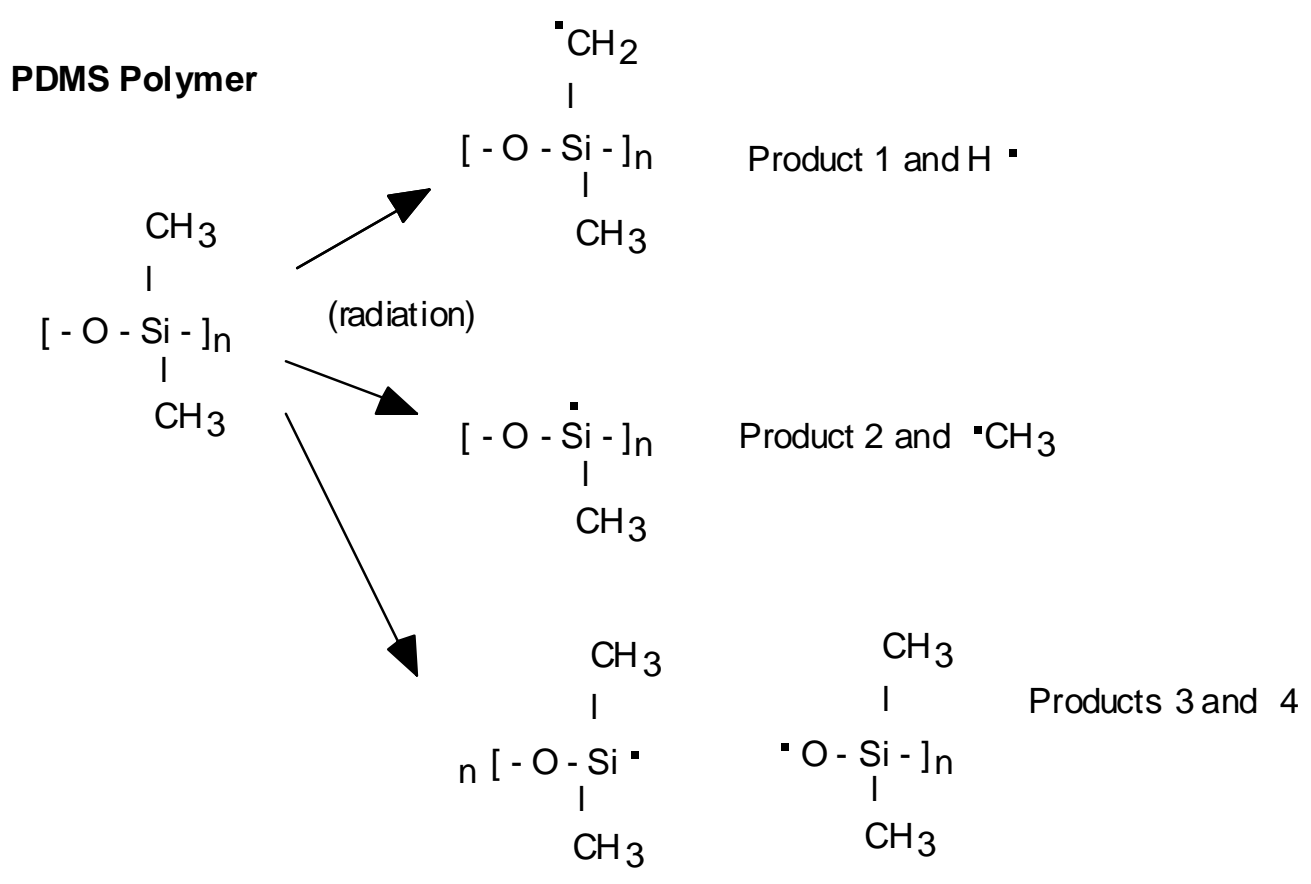

Figure 4-3. PDMS Polymer Direct Radiolytic Decomposition Scheme

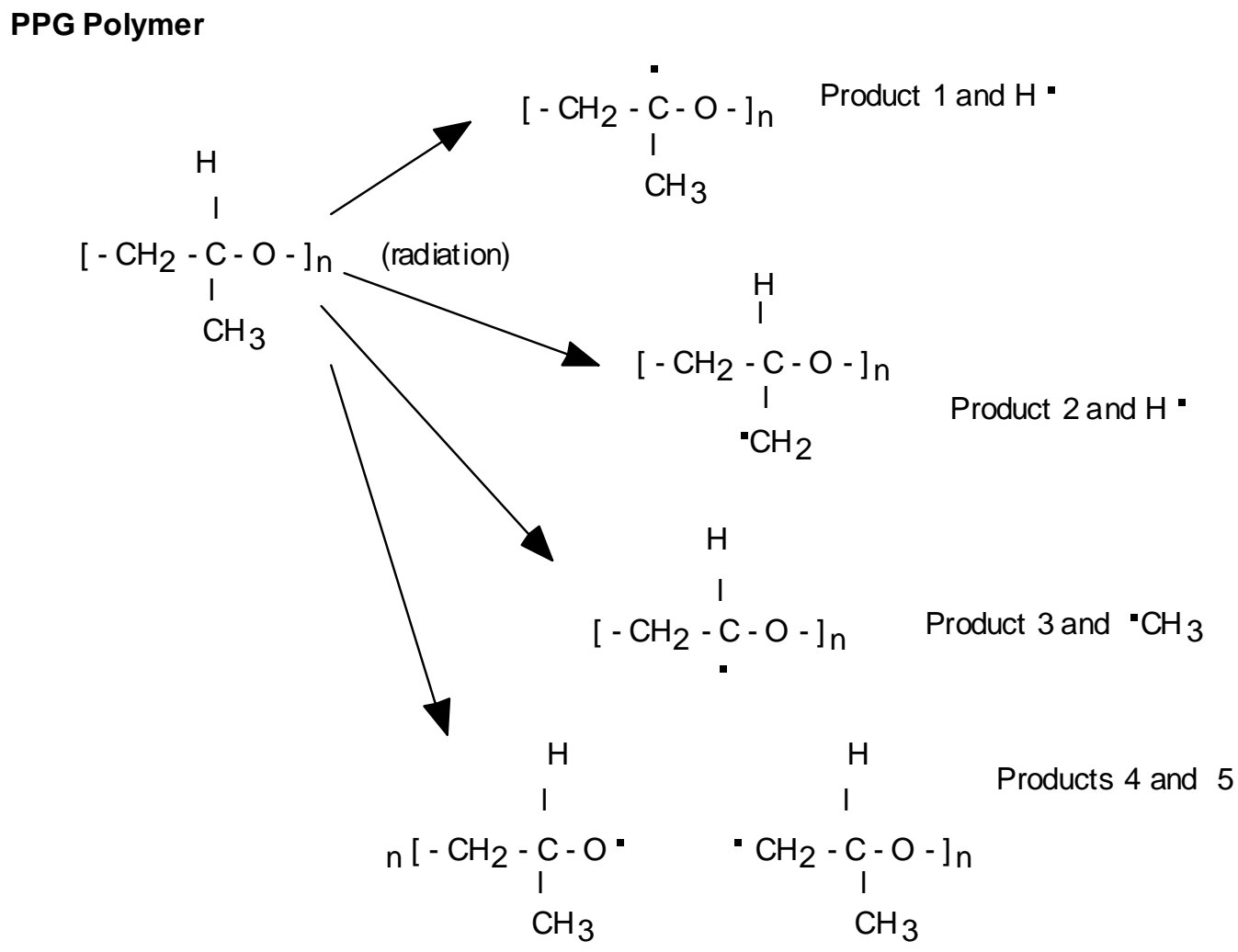

Figure 4-4. PPG Polymer Direct Radiolytic Decomposition Scheme 
WSRC-TR-2005-00281, REVISION 0

SRNL-RPP-2005-00040, REVISION 0

\subsection{CONCLUSIONS}

Results from this study indicate that the WTP HGR correlation bounds hydrogen generation rates (HGRs) from the combination of radiolysis/thermolysis of antifoam-containing simulants if the antifoam organic components are treated the same as native organics. Tests were conducted at the maximum process temperature of $90^{\circ} \mathrm{C}$. Tests conducted with thermal-only exposures following irradiations were inconclusive and need to be repeated with different methodology if this data is necessary.

Analysis of antifoam-containing simulants after prolonged irradiation of $52 \mathrm{Mrad}$ and heating (23 days at $90^{\circ} \mathrm{C}$ ) indicates that essentially all of the PDMS and greater than $60 \%$ of the PPG components are degraded presumably to lower molecular weight species. The antifoam components were analyzed by extraction from the salt simulants, followed by gel permeation chromatography (GPC) by personnel at Dow Corning. Dose rates used in the current testing were higher than anticipated dose rates in the WTP in order to ensure enough hydrogen gas was produced for measurement. Parallel testing using a more representative dose rate of $10 \mathrm{Ci} / \mathrm{L}$, or about $2 \mathrm{E} 10^{4} \mathrm{rad} / \mathrm{hr}$, will investigate the radiolytic and thermal degradation of the Q2-3183A antifoam (and degradation products) in more detail (Burket 2005b). 
WSRC-TR-2005-00281, REVISION 0

SRNL-RPP-2005-00040, REVISION 0

\subsection{REFERENCES}

Analytical Development Section (ADS) Procedure Manual L16-1, Procedure ADS-2255. 'OI Analytical 1020 High Temperature Total Organic Carbon (TOC) Analyzer with Autosampler'

Baich, M. A., Stone, M. E., White, T. L., Calloway, T. B. (2003) "Waste Treatment Plant LAW Evaporation: Antifoam Performance (U)," WSRC-TR-2003-00216, 2003. Rev. 0, Westinghouse Savannah River Company, August 2003.

Brook, M. A. (2000), Silicon in Organic, Organometallic, and Polymer Chemistry, WileyInterscience, New York, 2000.

Bryan, S. A. et al., (2004) "Gas Generation Testing and Support for the Hanford Waste Treatment and Immobilization Plant,” WPT-RPT-115, Rev. 0, June 2004.

Burket, P. R., Crawford, C. L., Duffey, C. E., Calloway, T. B. (2005a) "Task Technical and Quality Assurance Plan for $\mathrm{H}_{2}$ Generation Rate Scoping Study of DOW Corning Antifoam Agent,” WSRC-TR-2005-00144, Rev. 0, March 2005.

Burket, P. R., Crawford, C. L, White, T. L., Duffey, C. E., Calloway, T. B. (2005b) “Task Technical and Quality Assurance Plan for Evaluation of the Degradation Products and Rates of Anti-Foaming Agent in WTP Tanks Equipped with Pulse Jet Mixers and Air Spargers," WSRC-TR-2005-00127, Rev. 0, March 2005.

Chapiro, A. (1962), Radiation Chemistry of Polymeric Systems, Wiley-Interscience, New York, 1962.

Crawford, C. L. and Bibler, N. E., (1995) "Hydrogen Production in Radioactive Solutions in the Defense Waste Processing Facility," WSRC-TR-95-0090, Westinghouse Savannah River Company, June 28, 1995.

Daniel, W. E., (1999) "Hydrogen Generation During Melter Feed Preparation of Tank 42 Sludge and Salt Washed Loaded CST in the Defense Waste Processing Facility," WSRC-TR99-00277, Westinghouse Savannah River Company, August 23, 1999.

Fellinger, T. L., Pareizs, J. M., Bibler, N. E., Cozzi, A. D., Crawford, C. L., (2002) "Confirmation Run of the DWPF SRAT Cycle Using the Sludge-Only Flowsheet with Tank 40 Radioactive Sludge and Frit 200 in the Shielded Cells Facility,” WSRC-TR-2002-00076, Westinghouse Savannah River Company, April 30, 2002.

Hassan, N. M., Jones, T. M., Daniel, W. E. Hansen, E. K., Eibling, R. E. Calloway, T. B., (2004) "Evaluation of Foaming/Antifoaming In WTP Tanks Equipped With Pulse Jet Mixers And Air Spargers," WSRC-TR-2004-00387, Rev. 0, Westinghouse Savannah River Company, September 2004. 
WSRC-TR-2005-00281, REVISION 0

SRNL-RPP-2005-00040, REVISION 0

Implementation Letter CCN 116542, (2005) " $\mathrm{H}_{2}$ Generation Rate Scoping Study of DOW Corning Antifoam Agent,” March 22, 2005.

Koopman, D. C., (1999) “Comparison of Dow Corning 544 Antifoam to IIT747 Antifoam in the 1/240 SRAT," WSRC-TR-99-00377, Westinghouse Savannah River Company, December 17, 1999.

Koopman, D. C. and Lambert, D. P., (2001) "Hydrogen Generation and Foaming during Tests in the GFPS Simulating DWPF Operations with Tank 42 Sludge and CST," WSRCTR-99-00302, Rev. 1, Westinghouse Savannah River Company, September 10, 2001.

Lambert, D. P., (2000) “Testing of Irradiated and Nonirradiated IIT747 Antifoam in Simulated Sludge Processing," WSRC-RP-2000-00788, Westinghouse Savannah River Company, November 28, 2000.

Letter of Instruction CCN 114192, (2005) " $\mathrm{H}_{2}$ Generation Rate Scoping Study of DOW Corning Antifoam Agent,” March 2, 2005.

Saito, H. H. et al., (2001) “AN-107 (C) Simulant Bench-Scale LAW Evaporation with Organic Regulatory Analysis,” WSRC-TR-2000-00486, SRT-RPP-2000-00047, Westinghouse Savannah River Company, February 2001.

Sherwood, D. J. and L. M. Stock, (2004) "Modifying the Hu Correlation to Predict Hydrogen Formation in the Hanford Waste Treatment and Immobilization Plant," 24590-WTP-RPTRT-04-0002, Rev. 0, October 29, 2004.

Spinks, J. W. T. and R. J. Woods, (1990) An Introduction to Radiation Chemistry, John Wiley and Sons, Inc., New York, $3^{\text {rd }}$ Edition, 1990.

Swingle, R. F. II and T. L. White, (1999) "Contribution of Ammonia and Defoamers to Lower Flammability Limit in SRS High Level Waste Tanks,” WSRC-TR-99-00189, Westinghouse Savannah River Company, 1999. 
WSRC-TR-2005-00281, REVISION 0

SRNL-RPP-2005-00040, REVISION 0

This page intentionally left blank. 


\section{APPENDIX A. \\ SAMPLE CALCULATION OF MEASURED HGR AND MINIMUM HGR}

\section{$\underline{\text { Measured HGRs }}$}

The measured amount of hydrogen contained in the sample bulbs was used in the following calculation for all measured HGRs.

The equation used is:

$$
\mathrm{HGR}=\mathrm{g} \text {-moles } \mathrm{H}_{2} / \text { mass sample / exposure time } \quad \text { (Equation \#1) }
$$

The moles $\mathrm{H}_{2}$ were calculated using the measured vol $\% \mathrm{H}_{2}$ in the collected gas sample and the ideal gas law via,

$$
\text { g-moles } \mathrm{H}_{2}=\left(\mathrm{p}\left(\mathrm{H}_{2}\right)^{*} \mathrm{~V}\right) /(\mathrm{R} * \mathrm{~T}) \quad \text { (Equation \#2) }
$$

With $\mathrm{p}\left(\mathrm{H}_{2}\right)=\left(\right.$ final system absolute pressure at $\left.25^{\circ} \mathrm{C}\right) *$ vol $\%$ measured $\mathrm{H}_{2}$

$\mathrm{V}=$ measured head-space volume of each system

$\mathrm{R}=$ gas constant

$\mathrm{T}=25^{\circ} \mathrm{C}=298^{\circ} \mathrm{K}$

For the base simulant filtrate with no added antifoam,

$$
\begin{aligned}
& \mathrm{p}\left(\mathrm{H}_{2}\right)=34.2 \mathrm{psia}=2.33 \mathrm{~atm} *(4.66 / 100) \\
& \mathrm{V}=0.017 \mathrm{~L} \\
& \mathrm{R}=0.0820575 \mathrm{dm}^{3} \mathrm{~atm} / \mathrm{K}-\mathrm{mol} \\
& \mathrm{T}=25^{\circ} \mathrm{C}=298^{\circ} \mathrm{K} \\
& \text { Mass sample }=19.5474 \mathrm{~g}=0.0195474 \mathrm{~kg} \\
& \text { Exposure time }=11.95 \text { days }
\end{aligned}
$$

Substituting the above values into Equation \#2 gives,

$$
\text { g-moles } \mathrm{H}_{2}=(2.33 *(4.66 / 100) * 0.017) /(0.0820575 * 298)=7.54 \mathrm{E}-05 \mathrm{~mol} \mathrm{H}_{2}
$$

Substituting the calculated g-moles $\mathrm{H} 2$ and the sample mass and exposure time into Equation \#1 gives,

$$
\begin{aligned}
& \mathrm{HGR}=7.548 \mathrm{E}-05 \text { moles } \mathrm{H}_{2} / 0.0195474 \mathrm{~kg} / 11.95 \text { days } \\
& \mathrm{HGR}=3.23 \mathrm{E}-04 \mathrm{~g}-\mathrm{mol} / \mathrm{kg} / \text { day }
\end{aligned}
$$




\section{Minimum HGRs}

The minimum quantification limit determined for the mass spectroscopy hydrogen analysis was $\sim 100 \mathrm{ppm}$, or $0.01 \mathrm{vol} \% \mathrm{H}_{2}$. Assuming no measurable change in system pressure, i.e., pressure $=1 \mathrm{~atm}$, and all other parameters are the same as above (mass, temperature, headspace volume, irradiation time), substitution of these values into Equations \#1 and \#2 above gives a minimum HGR as:

$$
\begin{aligned}
& \text { g-moles } \mathrm{H}_{2}=(1 *(0.01 / 100) * 0.017) /(0.0820575 * 298)=6.9 \mathrm{E}-8 \mathrm{~mol} \mathrm{H}_{2} \\
& \mathrm{HGR}=6.9 \mathrm{E}-08 \text { moles } \mathrm{H}_{2} / 0.0195474 \mathrm{~kg} / 11.95 \text { days } \\
& \mathrm{HGR}=2.9 \mathrm{E}-07 \mathrm{~g}-\mathrm{mol} / \mathrm{kg} / \text { day }
\end{aligned}
$$


WSRC-TR-2005-00281, REVISION 0

SRNL-RPP-2005-00040, REVISION 0

\section{APPENDIX B. SIMULANT RECIPES}

Table B- 1. Base Simulant Recipe for 0 wt $\%$ TOC

\begin{tabular}{|c|c|c|c|c|c|c|c|}
\hline Component & $\begin{array}{l}\text { Molecular } \\
\text { weight }\end{array}$ & Concentration & Units & $\begin{array}{l}\text { Undiluted } \\
\text { Concentration }\end{array}$ & Units & $\%$ Carbon & $\begin{array}{l}\text { TOC } \\
\text { mg/Liter }\end{array}$ \\
\hline Acetate & 59.04462 & 0 & mg/Liter & $0.00 \mathrm{E}+00$ & $\mathrm{M}$ & 40.68 & 0 \\
\hline Aluminum & 26.98154 & 26982 & mg/Liter & $1.00 \mathrm{E}+00$ & $\mathrm{M}$ & & \\
\hline Ammonium & 18.03846 & 0 & mg/Liter & $0.00 \mathrm{E}+00$ & $M$ & & \\
\hline Barium & 137.33 & 0 & mg/Liter & $0.00 \mathrm{E}+00$ & $\mathrm{M}$ & & \\
\hline Boron & 10.81 & 0 & mg/Liter & $0.00 \mathrm{E}+00$ & $M$ & & \\
\hline Bromide & 79.904 & 0 & mg/Liter & $0.00 \mathrm{E}+00$ & $\mathrm{M}$ & & \\
\hline Cadmium & 112.41 & 5 & mg/Liter & 4.45E-05 & $\mathrm{M}$ & & \\
\hline Calcium & 40.08 & 0 & mg/Liter & $0.00 \mathrm{E}+00$ & $\mathrm{M}$ & & \\
\hline Carbonate & 60.0092 & 0 & mg/Liter & $0.00 \mathrm{E}+00$ & $\mathrm{M}$ & & \\
\hline Cerium & 140.12 & 0 & mg/Liter & $0.00 \mathrm{E}+00$ & $M$ & & \\
\hline Cesium & 132.9054 & 0 & mg/Liter & $0.00 \mathrm{E}+00$ & $\mathrm{M}$ & & \\
\hline Chloride & 35.453 & 5 & mg/Liter & $1.41 \mathrm{E}-04$ & $\mathrm{M}$ & & \\
\hline Chromium & 51.996 & 5 & mg/Liter & 9.62E-05 & $\mathrm{M}$ & & \\
\hline Cobalt & 58.9332 & 0 & mg/Liter & $0.00 \mathrm{E}+00$ & $M$ & & \\
\hline Copper & 63.546 & 5 & mg/Liter & 7.87E-05 & $\mathrm{M}$ & & \\
\hline EDTA & 288.20824 & 0 & mg/Liter & $0.00 \mathrm{E}+00$ & $\mathrm{M}$ & 41.67 & 0 \\
\hline Fluoride & 18.9984 & 0 & $\mathrm{mg} /$ Liter & $0.00 \mathrm{E}+00$ & $M$ & & \\
\hline Formate & 45.01774 & 0 & mg/Liter & $0.00 \mathrm{E}+00$ & $M$ & 26.68 & 0 \\
\hline Glycolate & 75.04206 & 0 & mg/Liter & $0.00 \mathrm{E}+00$ & $\mathrm{M}$ & 32.01 & 0 \\
\hline Hydroxide & 17.00734 & 1701 & mg/Liter & $1.00 \mathrm{E}-01$ & $\mathrm{M}$ & & \\
\hline Iron & 55.847 & 5 & mg/Liter & 8.95E-05 & $M$ & & \\
\hline Lanthanum & 138.9055 & 0 & mg/Liter & $0.00 \mathrm{E}+00$ & $M$ & & \\
\hline Lead & 207.2 & 0 & mg/Liter & $0.00 \mathrm{E}+00$ & $\mathrm{M}$ & & \\
\hline Magnesium & 24.305 & 0 & mg/Liter & $0.00 \mathrm{E}+00$ & $M$ & & \\
\hline Manganese & 54.938 & 0 & mg/Liter & $0.00 \mathrm{E}+00$ & $\mathrm{M}$ & & \\
\hline Molybdenum & 95.94 & 5 & mg/Liter & $5.21 \mathrm{E}-05$ & $M$ & & \\
\hline Neodymium & 144.24 & 0 & mg/Liter & $0.00 \mathrm{E}+00$ & $\mathrm{M}$ & & \\
\hline HEDTA & 275.23618 & 0 & mg/Liter & $0.00 \mathrm{E}+00$ & $\mathrm{M}$ & 43.64 & 0 \\
\hline Nickel & 58.69 & 5 & mg/Liter & 8.52E-05 & $\mathrm{M}$ & & \\
\hline Nitrate & 62.0049 & 186015 & mg/Liter & $3.00 \mathrm{E}+00$ & $\mathrm{M}$ & & \\
\hline Nitrite & 46.0055 & 138017 & mg/Liter & $3.00 \mathrm{E}+00$ & $\mathrm{M}$ & & \\
\hline Oxalate & 88.0196 & 0 & mg/Liter & $0.00 \mathrm{E}+00$ & $\mathrm{M}$ & 27.29 & 0 \\
\hline Phosphate & 94.97136 & 5 & mg/Liter & $5.26 \mathrm{E}-05$ & $\mathrm{M}$ & & \\
\hline Potassium & 39.0983 & 0 & mg/Liter & $0.00 \mathrm{E}+00$ & $\mathrm{M}$ & & \\
\hline Rubidium & 85.4678 & 0 & mg/Liter & $0.00 \mathrm{E}+00$ & $\mathrm{M}$ & & \\
\hline Selenium & 78.96 & 0 & mg/Liter & $0.00 \mathrm{E}+00$ & $\mathrm{M}$ & & \\
\hline Silicon & 28.0855 & 0 & mg/Liter & $0.00 \mathrm{E}+00$ & $\mathrm{M}$ & & \\
\hline Silver & 107.8682 & 0 & mg/Liter & $0.00 \mathrm{E}+00$ & $\mathrm{M}$ & & \\
\hline Sodium & 22.9898 & 163263 & mg/Liter & $7.102 \mathrm{E}+00$ & $M$ & & \\
\hline Strontium & 87.62 & 0 & mg/Liter & $0.000 \mathrm{E}+00$ & $M$ & & \\
\hline
\end{tabular}


WSRC-TR-2005-00281, REVISION 0

SRNL-RPP-2005-00040, REVISION 0

\begin{tabular}{|c|c|c|c|c|c|c|c|}
\hline Component & $\begin{array}{l}\text { Molecular } \\
\text { weight }\end{array}$ & Concentration & Units & $\begin{array}{l}\text { Undiluted } \\
\text { Concentration }\end{array}$ & Units & \% Carbon & $\begin{array}{l}\text { TOC } \\
\text { mg/Liter }\end{array}$ \\
\hline Sulfate & 96.0576 & 5 & mg/Liter & $5.21 \mathrm{E}-05$ & $M$ & & \\
\hline TIC & 12.011 & 0 & mg/Liter & $0.00 \mathrm{E}+00$ & $\mathrm{M}$ & & \\
\hline TOC & 12.011 & 0 & $\mathrm{mg} /$ Liter & 0.00 & $\mathrm{~g} / \mathrm{L}$ & & \\
\hline Tungsten & 183.85 & 0 & $\mathrm{mg} /$ Liter & $0.00 \mathrm{E}+00$ & $M$ & & \\
\hline Uranium & & 0 & $\mathrm{mg} /$ Liter & $0.00 \mathrm{E}+00$ & $\mathrm{ug} / \mathrm{mL}$ & & \\
\hline Zinc & 65.38 & 5 & $\mathrm{mg} /$ Liter & $7.65 \mathrm{E}-05$ & $M$ & & \\
\hline Zirconium & 91.22 & 0 & mg/Liter & $0.00 \mathrm{E}+00$ & M & & \\
\hline $\begin{array}{l}\text { Additional } \\
\text { Organic } \\
\text { Compounds }\end{array}$ & & & & & & \% Carbon & \\
\hline $\begin{array}{l}\text { Nitrilotriacetic } \\
\text { Acid }\end{array}$ & 188.12 & 0 & $\mathrm{mg} /$ Liter & $0.00 \mathrm{E}+00$ & M & 38.31 & 0 \\
\hline Citric Acid & 189.10 & 0 & $\mathrm{mg} /$ Liter & $0.00 \mathrm{E}+00$ & $M$ & 38.11 & 0 \\
\hline $\begin{array}{l}\text { Iminodiacetic } \\
\text { Acid }\end{array}$ & 131.08 & 0 & mg/Liter & $0.00 \mathrm{E}+00$ & M & 36.65 & 0 \\
\hline Succinic Acid & 116.07 & 0 & mg/Liter & $0.00 \mathrm{E}+00$ & $M$ & 41.39 & 0 \\
\hline Glutaric Acid & 130.09 & 0 & mg/Liter & $0.00 \mathrm{E}+00$ & $M$ & 46.16 & 0 \\
\hline Adipic Acid & 144.12 & 0 & $\mathrm{mg} /$ Liter & $0.00 \mathrm{E}+00$ & $M$ & 50.00 & 0 \\
\hline Azelaic Acid & 186.20 & 0 & $\mathrm{mg} /$ Liter & $0.00 \mathrm{E}+00$ & $\mathrm{M}$ & 58.05 & 0 \\
\hline Suberic Acid & 172.17 & 0 & mg/Liter & $0.00 \mathrm{E}+00$ & $M$ & 55.81 & 0 \\
\hline $\begin{array}{l}\text { Sodium } \\
\text { Gluconate }\end{array}$ & 218.14 & 0 & mg/Liter & $0.00 \mathrm{E}+00$ & M & 33.04 & 0 \\
\hline & & & & & & Total : & 0 \\
\hline Density (average) & & 1.4 & & & & & \\
\hline $\begin{array}{l}\text { Planned wt \% } \\
\text { TOC }\end{array}$ & & 0 & & & & & \\
\hline
\end{tabular}


WSRC-TR-2005-00281, REVISION 0

SRNL-RPP-2005-00040, REVISION 0

Table B- 2. Batching Recipe for 1000-mL Base Simulant 0 wt $\%$ TOC

\begin{tabular}{|c|c|c|}
\hline Volumetric Flask Tare Weight & & grams \\
\hline \multicolumn{3}{|l|}{ To the Volumetric Flask add: } \\
\hline & grams & Actual Wt, grams \\
\hline Water & 100 & \\
\hline \multicolumn{3}{|c|}{ Transition Metals and Complexing agents } \\
\hline Compounds & Formula & Mass Needed \\
\hline Cadmium Nitrate & $\mathrm{Cd}(\mathrm{NO} 3) 2.4 \mathrm{H} 2 \mathrm{O}$ & 0.01 \\
\hline Calcium Nitrate & $\mathrm{Ca}(\mathrm{NO} 3) 2.4 \mathrm{H} 2 \mathrm{O}$ & 0.00 \\
\hline Cerium Nitrate & $\mathrm{Ce}(\mathrm{NO} 3) 3.6 \mathrm{H} 2 \mathrm{O}$ & 0.00 \\
\hline Cesium Nitrate & $\mathrm{CsNO3}$ & 0.00 \\
\hline Cobalt Nitrate & $\mathrm{Co}(\mathrm{NO} 3) 2.6 \mathrm{H} 2 \mathrm{O}$ & 0.00 \\
\hline Copper Nitrate & $\mathrm{Cu}(\mathrm{NO} 3) 2.2 .5 \mathrm{H} 2 \mathrm{O}$ & 0.02 \\
\hline Ferric Nitrate & $\mathrm{Fe}(\mathrm{NO} 3) 3.9 \mathrm{H} 2 \mathrm{O}$ & 0.04 \\
\hline Lanthanum Nitrate & $\mathrm{La}(\mathrm{NO} 3) 3.6 \mathrm{H} 2 \mathrm{O}$ & 0.00 \\
\hline Lead nitrate & $\mathrm{Pb}(\mathrm{NO} 3) 2$ & 0.00 \\
\hline Magnesium Nitrate & $\mathrm{Mg}(\mathrm{NO} 3) 2.6 \mathrm{H} 2 \mathrm{O}$ & 0.00 \\
\hline Manganous Chloride & $\mathrm{MnCl} 2.4 \mathrm{H} 2 \mathrm{O}$ & 0.00 \\
\hline Neodymium Nitrate & $\mathrm{Nd}(\mathrm{NO} 3) 3.6 \mathrm{H} 2 \mathrm{O}$ & 0.00 \\
\hline Nickel Nitrate & $\mathrm{Ni}(\mathrm{NO} 3) 2.6 \mathrm{H} 2 \mathrm{O}$ & 0.02 \\
\hline Potassium Nitrate & KNO3 & 0.00 \\
\hline Rubidium Nitrate & $\mathrm{RbNO3}$ & 0.00 \\
\hline Strontium Nitrate & $\mathrm{Sr}(\mathrm{NO} 3) 2$ & 0.00 \\
\hline Zinc Nitrate & $\mathrm{Zn}(\mathrm{NO} 3) 2.6 \mathrm{H} 2 \mathrm{O}$ & 0.02 \\
\hline Zirconyl Nitrate & $\mathrm{ZrO}(\mathrm{NO} 3) 2 . \mathrm{H} 2 \mathrm{O}$ & 0.00 \\
\hline Disodium Ethylenediaminetetraacetate & $\mathrm{Na} 2 \mathrm{C} 10 \mathrm{H} 14 \mathrm{~N} 2 \mathrm{O} 8.2 \mathrm{H} 2 \mathrm{O}$ & 0.00 \\
\hline $\begin{array}{l}\text { n-(2- } \\
\text { Hydroxyethyl)ethylenediaminetriacetic } \\
\text { acid }\end{array}$ & $\mathrm{C} 10 \mathrm{H} 18 \mathrm{~N} 2 \mathrm{O} 7$ & 0.00 \\
\hline Sodium Gluconate & $\mathrm{HOCH} 2(\mathrm{CHOH}) 4 \mathrm{COONa}$ & 0.00 \\
\hline Citric Acid & $\mathrm{C} 6 \mathrm{H} 8 \mathrm{O} 7 . \mathrm{H} 2 \mathrm{O}$ & 0.00 \\
\hline Nitrilotriacetic Acid & C6H9NO6 & 0.00 \\
\hline Iminodiacetic Acid & $\mathrm{C} 4 \mathrm{H} 7 \mathrm{NO} 4$ & 0.00 \\
\hline Succinic Acid & $\mathrm{C} 4 \mathrm{H} 6 \mathrm{O} 4$ & 0.00 \\
\hline Glutaric Acid & $\mathrm{C} 5 \mathrm{H} 8 \mathrm{O} 4$ & 0.00 \\
\hline Adipic Acid & $\mathrm{C} 6 \mathrm{H} 10 \mathrm{O} 4$ & 0.00 \\
\hline Azelaic Acid & $\mathrm{C} 9 \mathrm{H} 16 \mathrm{O} 4$ & 0.00 \\
\hline Suberic Acid & $\mathrm{C} 8 \mathrm{H} 14 \mathrm{O} 4$ & 0.00 \\
\hline Boric acid & $\mathrm{H} 3 \mathrm{BO} 3$ & 0.00 \\
\hline Ammonium Acetate & $\mathrm{NH} 4 \mathrm{CH} 3 \mathrm{COO}$ & 0.00 \\
\hline Sodium Chloride & $\mathrm{NaCl}$ & 0.01 \\
\hline Sodium Fluoride & $\mathrm{NaF}$ & 0.00 \\
\hline Sodium Sulfate & $\mathrm{Na} 2 \mathrm{SO} 4$ & 0.01 \\
\hline Sodium Molybdate & $\mathrm{Na} 2 \mathrm{MoO} 4.2 \mathrm{H} 2 \mathrm{O}$ & 0.01 \\
\hline
\end{tabular}


WSRC-TR-2005-00281, REVISION 0

SRNL-RPP-2005-00040, REVISION 0

\begin{tabular}{|c|c|c|}
\hline $\begin{array}{l}\text { In separate container mix the } \\
\text { following }\end{array}$ & & \\
\hline Add & Formula & Mass Needed \\
\hline Sodium Hydroxide & $\mathrm{NaOH}$ & 164.06 \\
\hline Aluminum Nitrate & $\mathrm{Al}(\mathrm{NO} 3) 3.9 \mathrm{H} 2 \mathrm{O}$ & 375.13 \\
\hline Sodium Phosphate & $\mathrm{Na} 3 \mathrm{PO} 4.12 \mathrm{H} 2 \mathrm{O}$ & 0.02 \\
\hline Sodium Tungstate & $\mathrm{Na} 2 \mathrm{WO} 4.2 \mathrm{H} 2 \mathrm{O}$ & 0.00 \\
\hline Sodium Metasilicate & $\mathrm{Na} 2 \mathrm{SiO} 3.9 \mathrm{H} 2 \mathrm{O}$ & 0.00 \\
\hline Sodium Glycolate & $\mathrm{HOCH} 2 \mathrm{COONa}$ & 0.00 \\
\hline Sodium formate & $\mathrm{NaHCOO}$ & 0.00 \\
\hline Sodium Acetate & $\mathrm{NaCH} 3 \mathrm{COO} .3 \mathrm{H} 2 \mathrm{O}$ & 0.00 \\
\hline Sodium Oxalate & $\mathrm{Na} 2 \mathrm{C} 2 \mathrm{O} 4$ & 0.00 \\
\hline Add & grams & Actual Wt, grams \\
\hline Water & 200 & \\
\hline \multicolumn{3}{|c|}{ Mix thoroughly. Then add this solution to the volumetric flask. } \\
\hline Add & \begin{tabular}{l|l} 
Formula & \\
\end{tabular} & Mass Needed \\
\hline Sodium Chromate & $\mathrm{Na} 2 \mathrm{CrO} 4$ & 0.02 \\
\hline Sodium Carbonate & $\mathrm{Na} 2 \mathrm{CO} 3$ & 0.00 \\
\hline \multicolumn{3}{|l|}{ Mix thoroughly. } \\
\hline Mix & Formula & Mass Needed \\
\hline Sodium Nitrate & NaNO3 & 0.00 \\
\hline Sodium Nitrite & $\mathrm{NaNO} 2$ & 207.00 \\
\hline Water & & 100 \\
\hline \multicolumn{3}{|l|}{ Add and Mix thoroughly. } \\
\hline \multicolumn{3}{|l|}{$\begin{array}{l}\text { Mix thoroughly and dilute to the } \\
\text { mark. }\end{array}$} \\
\hline Record Final Gross Weight & & grams \\
\hline Measure the Density & & $\mathrm{g} / \mathrm{mL}$ \\
\hline \multicolumn{3}{|l|}{ For INFO ONLY } \\
\hline The final addition of water would be & & 175.18 \\
\hline a density of & 1.322 & $\mathrm{~g} / \mathrm{mL}$ \\
\hline Solution Labeling & Generic recipe at $0 \mathrm{wt}$ & $\%$ TOC \\
\hline
\end{tabular}


WSRC-TR-2005-00281, REVISION 0

SRNL-RPP-2005-00040, REVISION 0

Table B- 3. Native Simulant Recipe for 4 wt $\%$ TOC

\begin{tabular}{|c|c|c|c|c|c|c|c|}
\hline Component & $\begin{array}{l}\text { Molecular } \\
\text { weight }\end{array}$ & Concentration & Units & $\begin{array}{l}\text { Undiluted } \\
\text { Concentration }\end{array}$ & Units & $\begin{array}{c}\% \\
\text { Carbon }\end{array}$ & $\begin{array}{c}\text { TOC } \\
\text { mg/Liter }\end{array}$ \\
\hline Acetate & 59.04462 & 0 & mg/Liter & $0.00 \mathrm{E}+00$ & $M$ & 40.68 & 0 \\
\hline Aluminum & 26.98154 & 26982 & $\mathrm{mg} /$ Liter & $1.00 \mathrm{E}+00$ & $\mathrm{M}$ & & \\
\hline Ammonium & 18.03846 & 0 & mg/Liter & $0.00 \mathrm{E}+00$ & $\mathrm{M}$ & & \\
\hline Barium & 137.33 & 0 & $\mathrm{mg} /$ Liter & $0.00 \mathrm{E}+00$ & $\mathrm{M}$ & & \\
\hline Boron & 10.81 & 0 & $\mathrm{mg} /$ Liter & $0.00 E+00$ & $M$ & & \\
\hline Bromide & 79.904 & 0 & $\mathrm{mg} /$ Liter & $0.00 \mathrm{E}+00$ & $M$ & & \\
\hline Cadmium & 112.41 & 5 & mg/Liter & $4.45 \mathrm{E}-05$ & $\mathrm{M}$ & & \\
\hline Calcium & 40.08 & 0 & mg/Liter & $0.00 \mathrm{E}+00$ & $\mathrm{M}$ & & \\
\hline Carbonate & 60.0092 & 0 & $\mathrm{mg} / \mathrm{Liter}$ & $0.00 \mathrm{E}+00$ & $\mathrm{M}$ & & \\
\hline Cerium & 140.12 & 0 & $\mathrm{mg} /$ Liter & $0.00 \mathrm{E}+00$ & $\mathrm{M}$ & & \\
\hline Cesium & 132.9054 & 0 & mg/Liter & $0.00 \mathrm{E}+00$ & $\mathrm{M}$ & & \\
\hline Chloride & 35.453 & 5 & mg/Liter & 1.41E-04 & $M$ & & \\
\hline Chromium & 51.996 & 5 & mg/Liter & 9.62E-05 & $M$ & & \\
\hline Cobalt & 58.9332 & 0 & mg/Liter & $0.00 \mathrm{E}+00$ & $\mathrm{M}$ & & \\
\hline Copper & 63.546 & 5 & mg/Liter & 7.87E-05 & $\mathrm{M}$ & & \\
\hline EDTA & 288.20824 & 0 & mg/Liter & $0.00 \mathrm{E}+00$ & $\mathrm{M}$ & 41.67 & 0 \\
\hline Fluoride & 18.9984 & 0 & $\mathrm{mg} /$ Liter & $0.00 \mathrm{E}+00$ & $\mathrm{M}$ & & \\
\hline Formate & 45.01774 & 0 & $\mathrm{mg} /$ Liter & $0.00 \mathrm{E}+00$ & $\mathrm{M}$ & 26.68 & 0 \\
\hline Glycolate & 75.04206 & 132911 & $\mathrm{mg} /$ Liter & $1.77 \mathrm{E}+00$ & $\mathrm{M}$ & 32.01 & 42547 \\
\hline Hydroxide & 17.00734 & 1701 & mg/Liter & $1.00 \mathrm{E}-01$ & $\mathrm{M}$ & & \\
\hline Iron & 55.847 & 5 & mg/Liter & 8.95E-05 & $\mathrm{M}$ & & \\
\hline Lanthanum & 138.9055 & 0 & mg/Liter & $0.00 \mathrm{E}+00$ & $\mathrm{M}$ & & \\
\hline Lead & 207.2 & 0 & $\mathrm{mg} /$ Liter & $0.00 \mathrm{E}+00$ & $\mathrm{M}$ & & \\
\hline Magnesium & 24.305 & 0 & $\mathrm{mg} /$ Liter & $0.00 \mathrm{E}+00$ & $\mathrm{M}$ & & \\
\hline Manganese & 54.938 & 0 & $\mathrm{mg} /$ Liter & $0.00 \mathrm{E}+00$ & $\mathrm{M}$ & & \\
\hline Molybdenum & 95.94 & 5 & $\mathrm{mg} /$ Liter & $5.21 \mathrm{E}-05$ & $\mathrm{M}$ & & \\
\hline Neodymium & 144.24 & 0 & $\mathrm{mg} /$ Liter & $0.00 \mathrm{E}+00$ & $M$ & & \\
\hline HEDTA & 275.23618 & 32407 & mg/Liter & $1.18 \mathrm{E}-01$ & $\mathrm{M}$ & 43.64 & 14142 \\
\hline Nickel & 58.69 & 5 & mg/Liter & $8.52 \mathrm{E}-05$ & $\mathrm{M}$ & & \\
\hline Nitrate & 62.0049 & 186015 & $\mathrm{mg} /$ Liter & $3.00 \mathrm{E}+00$ & $\mathrm{M}$ & & \\
\hline Nitrite & 46.0055 & 138017 & $\mathrm{mg} /$ Liter & $3.00 \mathrm{E}+00$ & $\mathrm{M}$ & & \\
\hline Oxalate & 88.0196 & 0 & $\mathrm{mg} /$ Liter & $0.00 \mathrm{E}+00$ & $\mathrm{M}$ & 27.29 & 0 \\
\hline Phosphate & 94.97136 & 5 & $\mathrm{mg} /$ Liter & 5.26E-05 & $\mathrm{M}$ & & \\
\hline Potassium & 39.0983 & 0 & $\mathrm{mg} /$ Liter & $0.00 \mathrm{E}+00$ & $\mathrm{M}$ & & \\
\hline Rubidium & 85.4678 & 0 & mg/Liter & $0.00 \mathrm{E}+00$ & $\mathrm{M}$ & & \\
\hline Selenium & 78.96 & 0 & mg/Liter & $0.00 \mathrm{E}+00$ & $\mathrm{M}$ & & \\
\hline Silicon & 28.0855 & 0 & $\mathrm{mg} / \mathrm{Liter}$ & $0.00 \mathrm{E}+00$ & $\mathrm{M}$ & & \\
\hline Silver & 107.8682 & 0 & $\mathrm{mg} /$ Liter & $0.00 \mathrm{E}+00$ & $M$ & & \\
\hline Sodium & 22.9898 & 212102 & $\mathrm{mg} /$ Liter & $9.226 \mathrm{E}+00$ & $M$ & & \\
\hline Strontium & 87.62 & 0 & $\mathrm{mg} /$ Liter & $0.000 \mathrm{E}+00$ & $M$ & & \\
\hline Sulfate & 96.0576 & 5 & $\mathrm{mg} /$ Liter & 5.21E-05 & $M$ & & \\
\hline TIC & 12.011 & 0 & mg/Liter & $0.00 \mathrm{E}+00$ & $M$ & & \\
\hline TOC & 12.011 & 56000 & $\mathrm{mg} /$ Liter & 56.00 & $g / L$ & & \\
\hline
\end{tabular}


WSRC-TR-2005-00281, REVISION 0

SRNL-RPP-2005-00040, REVISION 0

\begin{tabular}{|l|r|r|r|r|r|r|r|}
\hline Component & $\begin{array}{l}\text { Molecular } \\
\text { weight }\end{array}$ & Concentration & Units & $\begin{array}{l}\text { Undiluted } \\
\text { Concentration }\end{array}$ & Units & $\begin{array}{c}\text { \% } \\
\text { Carbon }\end{array}$ & $\begin{array}{c}\text { TOC } \\
\text { mg/Liter }\end{array}$ \\
\hline Tungsten & 183.85 & 0 & $\mathrm{mg} / \mathrm{Liter}$ & $0.00 \mathrm{E}+00$ & $\mathrm{M}$ & & \\
\hline Uranium & & 0 & $\mathrm{mg} / \mathrm{Liter}$ & $0.00 \mathrm{E}+00$ & $\mathrm{ug} / \mathrm{mL}$ & & \\
\hline Zinc & 65.38 & 5 & $\mathrm{mg} / \mathrm{Liter}$ & $7.65 \mathrm{E}-05$ & $\mathrm{M}$ & & \\
\hline Zirconium & 91.22 & 0 & $\mathrm{mg} / \mathrm{Liter}$ & $0.00 \mathrm{E}+00$ & $\mathrm{M}$ & & \\
\hline $\begin{array}{l}\text { Additional } \\
\text { Organic } \\
\text { Compounds }\end{array}$ & & & & & & & \\
\hline Nitrilotriacetic Acid & 188.12 & & & & & Carbon & \\
\hline Citric Acid & 189.10 & 0 & $\mathrm{mg} / \mathrm{Liter}$ & $0.00 \mathrm{E}+00$ & $\mathrm{M}$ & 38.31 & 0 \\
\hline Iminodiacetic Acid & 131.08 & 0 & $\mathrm{mg} / \mathrm{Liter}$ & $0.00 \mathrm{E}+00$ & $\mathrm{M}$ & 38.11 & 0 \\
\hline Succinic Acid & 116.07 & 0 & $\mathrm{mg} / \mathrm{Liter}$ & $0.00 \mathrm{E}+00$ & $\mathrm{M}$ & 36.65 & 0 \\
\hline Glutaric Acid & 130.09 & 0 & $\mathrm{mg} / \mathrm{Liter}$ & $0.00 \mathrm{E}+00$ & $\mathrm{M}$ & 41.39 & 0 \\
\hline Adipic Acid & 144.12 & 0 & $\mathrm{mg} / \mathrm{Liter}$ & $0.00 \mathrm{E}+00$ & $\mathrm{M}$ & 46.16 & 0 \\
\hline Azelaic Acid & 186.20 & 0 & $\mathrm{mg} / \mathrm{Liter}$ & $0.00 \mathrm{E}+00$ & $\mathrm{M}$ & 50.00 & 0 \\
\hline Suberic Acid & 172.17 & 0 & $\mathrm{mg} / \mathrm{Liter}$ & $0.00 \mathrm{E}+00$ & $\mathrm{M}$ & 58.05 & 0 \\
\hline Sodium Gluconate & 218.14 & 0 & $\mathrm{mg} / \mathrm{Liter}$ & $0.00 \mathrm{E}+00$ & $\mathrm{M}$ & 55.81 & 0 \\
\hline & & 0 & $\mathrm{mg} / \mathrm{Liter}$ & $0.00 \mathrm{E}+00$ & $\mathrm{M}$ & 33.04 & 0 \\
\hline Density (average) & & & & & Total : & 56689 \\
\hline Planned wt \% TOC & & 1.4 & & & & & \\
\hline
\end{tabular}


WSRC-TR-2005-00281, REVISION 0

SRNL-RPP-2005-00040, REVISION 0

Table B- 4. Batching Recipe for $4 \mathrm{wt} \%$ TOC

\begin{tabular}{|c|c|c|}
\hline Volumetric Flask Tare Weight & & grams \\
\hline \multicolumn{3}{|l|}{ To the Volumetric Flask add: } \\
\hline & grams & Actual Wt, grams \\
\hline Water & 100 & \\
\hline \multicolumn{3}{|c|}{ Transition Metals and Complexing agents } \\
\hline Compounds & Formula & Mass Needed \\
\hline Cadmium Nitrate & $\mathrm{Cd}(\mathrm{NO} 3) 2.4 \mathrm{H} 2 \mathrm{O}$ & 0.01 \\
\hline Calcium Nitrate & $\mathrm{Ca}(\mathrm{NO} 3) 2.4 \mathrm{H} 2 \mathrm{O}$ & 0.00 \\
\hline Cerium Nitrate & $\mathrm{Ce}(\mathrm{NO} 3) 3.6 \mathrm{H} 2 \mathrm{O}$ & 0.00 \\
\hline Cesium Nitrate & $\mathrm{CsNO3}$ & 0.000 \\
\hline Cobalt Nitrate & $\mathrm{Co}(\mathrm{NO} 3) 2.6 \mathrm{H} 2 \mathrm{O}$ & 0.00 \\
\hline Copper Nitrate & $\mathrm{Cu}(\mathrm{NO} 3) 2.2 .5 \mathrm{H} 2 \mathrm{O}$ & 0.02 \\
\hline Ferric Nitrate & $\mathrm{Fe}(\mathrm{NO} 3) 3.9 \mathrm{H} 2 \mathrm{O}$ & 0.04 \\
\hline Lanthanum Nitrate & $\mathrm{La}(\mathrm{NO} 3) 3.6 \mathrm{H} 2 \mathrm{O}$ & 0.00 \\
\hline Lead nitrate & $\mathrm{Pb}(\mathrm{NO} 3) 2$ & 0.00 \\
\hline Magnesium Nitrate & $\mathrm{Mg}(\mathrm{NO} 3) 2.6 \mathrm{H} 2 \mathrm{O}$ & 0.00 \\
\hline Manganous Chloride & $\mathrm{MnCl} 2.4 \mathrm{H} 2 \mathrm{O}$ & 0.00 \\
\hline Neodymium Nitrate & $\mathrm{Nd}(\mathrm{NO} 3) 3.6 \mathrm{H} 2 \mathrm{O}$ & 0.00 \\
\hline Nickel Nitrate & $\mathrm{Ni}(\mathrm{NO} 3) 2.6 \mathrm{H} 2 \mathrm{O}$ & 0.02 \\
\hline Potassium Nitrate & KNO3 & 0.00 \\
\hline Rubidium Nitrate & $\mathrm{RbNO3}$ & 0.00 \\
\hline Strontium Nitrate & $\mathrm{Sr}(\mathrm{NO} 3) 2$ & 0.000 \\
\hline Zinc Nitrate & $\mathrm{Zn}(\mathrm{NO} 3) 2.6 \mathrm{H} 2 \mathrm{O}$ & 0.02 \\
\hline Zirconyl Nitrate & $\mathrm{ZrO}(\mathrm{NO} 3) 2 . \mathrm{H} 2 \mathrm{O}$ & 0.00 \\
\hline Disodium Ethylenediaminetetraacetate & $\mathrm{Na} 2 \mathrm{C} 10 \mathrm{H} 14 \mathrm{~N} 2 \mathrm{O} 8.2 \mathrm{H} 2 \mathrm{O}$ & 0.00 \\
\hline $\begin{array}{l}\text { n-(2- } \\
\text { Hydroxyethyl)ethylenediaminetriacetic } \\
\text { acid }\end{array}$ & $\mathrm{C} 10 \mathrm{H} 18 \mathrm{~N} 2 \mathrm{O} 7$ & 32.76 \\
\hline Sodium Gluconate & $\mathrm{HOCH} 2(\mathrm{CHOH}) 4 \mathrm{COONa}$ & 0.00 \\
\hline Citric Acid & $\mathrm{C} 6 \mathrm{H} 8 \mathrm{O} 7 . \mathrm{H} 2 \mathrm{O}$ & 0.00 \\
\hline Nitrilotriacetic Acid & C6H9NO6 & 0.00 \\
\hline Iminodiacetic Acid & $\mathrm{C} 4 \mathrm{H} 7 \mathrm{NO} 4$ & 0.00 \\
\hline Succinic Acid & $\mathrm{C} 4 \mathrm{H} 6 \mathrm{O} 4$ & 0.00 \\
\hline Glutaric Acid & $\mathrm{C} 5 \mathrm{H} 8 \mathrm{O} 4$ & 0.00 \\
\hline Adipic Acid & $\mathrm{C} 6 \mathrm{H} 10 \mathrm{O} 4$ & 0.00 \\
\hline Azelaic Acid & $\mathrm{C} 9 \mathrm{H} 16 \mathrm{O} 4$ & 0.00 \\
\hline Suberic Acid & $\mathrm{C} 8 \mathrm{H} 14 \mathrm{O} 4$ & 0.00 \\
\hline Boric acid & $\mathrm{H} 3 \mathrm{BO} 3$ & 0.00 \\
\hline Ammonium Acetate & $\mathrm{NH} 4 \mathrm{CH} 3 \mathrm{COO}$ & 0.00 \\
\hline Sodium Chloride & $\mathrm{NaCl}$ & 0.01 \\
\hline Sodium Fluoride & $\mathrm{NaF}$ & 0.00 \\
\hline Sodium Sulfate & $\mathrm{Na} 2 \mathrm{SO} 4$ & 0.01 \\
\hline Sodium Molybdate & $\mathrm{Na} 2 \mathrm{MoO} 4.2 \mathrm{H} 2 \mathrm{O}$ & 0.01 \\
\hline
\end{tabular}


WSRC-TR-2005-00281, REVISION 0

SRNL-RPP-2005-00040, REVISION 0

\begin{tabular}{|c|c|c|}
\hline $\begin{array}{l}\text { In separate container mix the } \\
\text { following }\end{array}$ & & \\
\hline Add & Formula & Mass Needed \\
\hline Sodium Hydroxide & $\mathrm{NaOH}$ & 178.18 \\
\hline Aluminum Nitrate & $\mathrm{Al}(\mathrm{NO} 3) 3.9 \mathrm{H} 2 \mathrm{O}$ & 375.13 \\
\hline Sodium Phosphate & $\mathrm{Na3PO} 4.12 \mathrm{H} 2 \mathrm{O}$ & 0.02 \\
\hline Sodium Tungstate & $\mathrm{Na} 2 \mathrm{WO} 4.2 \mathrm{H} 2 \mathrm{O}$ & 0.00 \\
\hline Sodium Metasilicate & $\mathrm{Na} 2 \mathrm{SiO} 3.9 \mathrm{H} 2 \mathrm{O}$ & 0.00 \\
\hline Sodium Glycolate & $\mathrm{HOCH} 2 \mathrm{COONa}$ & 173.63 \\
\hline Sodium formate & $\mathrm{NaHCOO}$ & 0.00 \\
\hline Sodium Acetate & $\mathrm{NaCH} 3 \mathrm{COO} .3 \mathrm{H} 2 \mathrm{O}$ & 0.00 \\
\hline Sodium Oxalate & $\mathrm{Na} 2 \mathrm{C} 2 \mathrm{O} 4$ & 0.00 \\
\hline Add & grams & Actual Wt, grams \\
\hline Water & 200 & \\
\hline \multicolumn{3}{|c|}{ Mix thoroughly. Then add this solution to the volumetric flask. } \\
\hline Add & Formula & Mass Needed \\
\hline Sodium Chromate & $\mathrm{Na} 2 \mathrm{CrO} 4$ & 0.02 \\
\hline Sodium Carbonate & $\mathrm{Na} 2 \mathrm{CO} 3$ & 0.00 \\
\hline \multicolumn{3}{|l|}{ Mix thoroughly. } \\
\hline Mix & Formula & Mass Needed \\
\hline Sodium Nitrate & NaNO3 & 0.00 \\
\hline Sodium Nitrite & $\mathrm{NaNO} 2$ & 207.00 \\
\hline Water & & 100 \\
\hline \multicolumn{3}{|l|}{ Add and Mix thoroughly. } \\
\hline \multicolumn{3}{|l|}{$\begin{array}{l}\text { Mix thoroughly and dilute to the } \\
\text { mark. }\end{array}$} \\
\hline Record Final Gross Weight & & grams \\
\hline Measure the Density & & $\mathrm{g} / \mathrm{mL}$ \\
\hline \multicolumn{3}{|l|}{ For INFO ONLY } \\
\hline The final addition of water would be & & 36.82 \\
\hline a density of & 1.404 & $\mathrm{~g} / \mathrm{mL}$ \\
\hline Solution Labeling & Generic recipe at $4 \mathrm{w}$ & $\%$ TOC \\
\hline
\end{tabular}


WSRC-TR-2005-00281, REVISION 0

SRNL-RPP-2005-00040, REVISION 0

APPENDIX C. WTP HGR CORRELATION 


\section{Text Box. WTP Project HGR CoRRELATION (Sherwood and Stock 2004)}

This correlation needs G-value terms for the radiolysis of water from alpha and beta/gamma sources, $G_{0}\left(\mathrm{H}_{2}\right)^{\alpha}$ and $G_{0}\left(\mathrm{H}_{2}\right)^{\beta / \gamma}$, and from interactions of the primary radiolysis products with organic compounds, $G_{\mathrm{TOC}}\left(\mathrm{H}_{2}\right)^{\alpha}$ and $G_{\mathrm{TOC}}\left(\mathrm{H}_{2}\right)^{\beta / \gamma}$. Units for the G-values are number of $\mathrm{H}_{2}$ molecules per $100 \mathrm{eV}$ of respective radiation absorbed by the waste.

The terms for water radiolysis from alpha and beta/gamma sources are:

$$
G_{0}\left(\mathrm{H}_{2}\right)^{\alpha}=1.05 /\left(1+2.4\left[\mathrm{NO}_{3}^{-}\right]+0.62\left[\mathrm{NO}_{2}^{-}\right]\right)+0.35 /\left(1+3900\left[\mathrm{NO}_{3}^{-}\right]+1400\left[\mathrm{NO}_{2}^{-}\right]\right),
$$

and

$$
G_{0}\left(\mathrm{H}_{2}\right)^{\beta / \gamma}=0.34 /\left(1+2.4\left[\mathrm{NO}_{3}^{-}\right]+0.62\left[\mathrm{NO}_{2}^{-}\right]\right)+0.11 /\left(1+120\left[\mathrm{NO}_{3}^{-}\right]+43\left[\mathrm{NO}_{2}^{-}\right]\right) .
$$

Here, the nitrate/nitrite concentrations are in moles/liter (M). G-values representing hydrogen formation from interactions of alpha and beta/gamma radiolysis products with dissolved organic compounds are:

and

$$
G_{\mathrm{TOC}}\left(\mathrm{H}_{2}\right)^{\alpha}=0.5 a_{0}(f[\mathrm{TOC}]) \exp \left(-Q_{\mathrm{rad}} / \mathrm{RT}\right),
$$

Here: $\quad a_{0}=2.49 \times 10^{6}$;

$$
G_{\mathrm{TOC}}\left(\mathrm{H}_{2}\right)^{\beta / \gamma}=a_{0}(f[\mathrm{TOC}]) \exp \left(-Q_{\mathrm{rad}} / \mathrm{RT}\right) .
$$

$f=$ "reactivity coefficient" for organic species; $f=0.7(0.4)$ for double-(single-)shell tank waste;

$[\mathrm{TOC}]=$ concentration in weight percent of total organic carbon in the liquid phase;

$Q_{\mathrm{rad}}=44,300 \mathrm{~J} / \mathrm{mol}$, activation energy;

$\mathrm{R}=8.314 \mathrm{~J} / \mathrm{K}-\mathrm{mol}$, the gas constant; and

$T$ denotes waste temperature in Kelvin.

The total G-values, $G\left(\mathrm{H}_{2}\right)$, for alpha and beta/gamma sources are just the respective sums of these G-values for radiolysis of water and interactions of radiolysis products with organic compounds:

and

$$
G\left(\mathrm{H}_{2}\right)^{\alpha}=G_{0}\left(\mathrm{H}_{2}\right)^{\alpha}+G_{\mathrm{TOC}}\left(\mathrm{H}_{2}\right)^{\alpha},
$$

$$
G\left(\mathrm{H}_{2}\right)^{\beta / \gamma}=G_{0}\left(\mathrm{H}_{2}\right)^{\beta / \gamma}+G_{\mathrm{TOC}}\left(\mathrm{H}_{2}\right)^{\beta / \gamma} .
$$

The hydrogen generation rate (HGR) results when the G-value terms are multiplied by appropriate factors:

$$
\boldsymbol{H} \boldsymbol{G} \boldsymbol{R}_{\text {rad }}=f_{\mathrm{L}} C\left[H^{\alpha} G\left(\mathrm{H}_{2}\right)^{\alpha}+H^{\beta / \gamma} G\left(\mathrm{H}_{2}\right)^{\beta / \gamma}\right] \text { gram-moles } \mathrm{H}_{2} / \text { day per kg-waste, }
$$

where: $H^{\alpha}$ and $H^{\beta / \gamma}$ are the respective decay heat loads for the waste in watt $/ \mathrm{kg}$;

$f_{\mathrm{L}}$ is the fraction of liquid in the waste; and

$C(=0.00895)$ is a conversion factor from (molecules $\left.\mathrm{H}_{2} / 100 \mathrm{eV}\right)($ watt $/ \mathrm{kg})$ to gram-moles of $\mathrm{H}_{2}$ per kg-day.

Thermolysis provides another source of hydrogen; the hydrogen generation rate is given directly as

$$
\boldsymbol{H} \boldsymbol{G} \boldsymbol{R}_{\text {therm }}=a_{\mathrm{T}}(f[\mathrm{TOC}])[\mathrm{Al}]^{0.4} f_{\mathrm{L}} \exp \left(-Q_{\mathrm{T}} / \mathrm{RT}\right) \text { gram-moles } \mathrm{H}_{2} / \text { day per kg-waste. }
$$

Here: $\quad a_{\mathrm{T}}=2.76 \times 10^{9}$;

$f=$ "reactivity coefficient" for organic species; $f=0.7(0.4)$ for double-(single-)shell tank waste;

$[\mathrm{TOC}]=$ concentration in weight percent of total organic carbon in the liquid phase;

$[\mathrm{Al}]=$ total concentration of aluminum species in liquid phase, in weight percent;

$f_{\mathrm{L}}=$ liquid weight fraction of waste;

$Q_{\mathrm{T}}=89,300 \mathrm{~J} / \mathrm{mol}$, activation energy;

$\mathrm{R}=8.314 \mathrm{~J} / \mathrm{K}-\mathrm{mol}$, the gas constant; and

$T$ is the waste temperature in Kelvin.

The total hydrogen generation rate is then: 


\section{WTP HGR Correlation Predictions for Antifoam Agent Addition Correlation Used As In Engineering Calculation}

David J. Sherwood

Waste Properties:

$\mathrm{i}:=0 . .3 \quad$ Liquid fraction, $f_{\mathrm{L}}:\left[\mathrm{NO}_{3}{ }^{-}\right](\mathrm{M}): \quad\left[\mathrm{NO}_{2}^{-}\right](\mathrm{M}): \quad$ Native $[\mathrm{TOC}](\mathrm{wt} . \%)$ :

\begin{tabular}{|c|c|c|c|c|}
\hline $\operatorname{Simulant}_{1}:=$ & $\mathrm{f}_{\mathrm{L}_{\mathrm{i}}}:=$ & NO3 $_{i}:=$ & $\mathrm{NO}_{\mathrm{i}}:=$ & $\operatorname{TOC}_{i}:=$ \\
\hline AN107_AFA & 1 & 2.34 & 0.84 & 0.87 \\
\hline B native & 1 & 2.64 & 2.55 & 1.24 \\
\hline C_LowAFA & 0.97 & 2.64 & 2.61 & 0 \\
\hline C_HighAFA & 0.89 & 2.64 & 2.61 & 0 \\
\hline
\end{tabular}

June 22, $2005 \quad$ [Al] (wt.\%): Native TOC Reactivity:

\begin{tabular}{l|l|}
$\mathrm{Al}_{\mathrm{i}}:=$ & $\mathrm{f}_{\mathrm{i}}:=$ \\
\hline 0.018 & 0.7 \\
\hline 1.6 & 0.7 \\
\hline 0.89 & 0 \\
\hline 0.89 & 0 \\
\hline
\end{tabular}

Exposure Conditions: Decay heat based on dose rate of $1.8 \times 10^{5} \mathrm{rad} /$ hour; $1 \mathrm{rad}=0.01 \mathrm{~W}$ s $/ \mathrm{kg}$; $3600 \mathrm{~s} / \mathrm{hr}$.

$$
\begin{array}{lll}
\mathrm{D}:=0.01 \cdot 1.8 \cdot 10^{5} \cdot \frac{1}{3600} \quad \mathrm{D}=0.50 \mathrm{~W} / \mathrm{kg} & H^{\beta / \gamma}(\mathrm{W} / \mathrm{kg}): & T\left({ }^{\circ} \mathrm{C}\right): \\
\mathrm{H}_{\mathrm{i}}:= & \mathrm{T}_{\mathrm{i}}:= \\
& \mathrm{D} & 90 \\
\hline \mathrm{D} & \\
\hline \mathrm{D} & \\
\hline \mathrm{D} & 90 \\
\hline 90
\end{array}
$$

Correlation Terms:

$$
\begin{aligned}
& \mathrm{G}_{0_{\mathrm{i}}}:=\frac{0.34}{1+2.4 \mathrm{NO}_{\mathrm{i}}+0.62 \cdot \mathrm{NO}_{\mathrm{i}}}+\frac{0.11}{1+120 \mathrm{NO}_{\mathrm{i}}+43 \cdot \mathrm{NO}_{\mathrm{i}}} \\
& \mathrm{G}_{\mathrm{TOC}_{\mathrm{i}}}:=2.4910^{6} \cdot\left(\mathrm{f}_{\mathrm{i}} \cdot \mathrm{TOC}_{\mathrm{i}}\right) \cdot \exp \left[\frac{-44300}{8.314\left(\mathrm{~T}_{\mathrm{i}}+273\right)}\right] \\
& \mathrm{HGR}_{\mathrm{rad}_{\mathrm{i}}}:=0.00895 \mathrm{f}_{\mathrm{i}} \cdot \mathrm{H}_{\mathrm{i}} \cdot\left(\mathrm{G}_{\mathrm{i}_{\mathrm{i}}}+\mathrm{G}_{\mathrm{TOC}_{\mathrm{i}}}\right) \\
& \mathrm{HGR}_{\text {therm }_{\mathrm{i}}}:=2.7610^{9} \cdot \mathrm{f}_{\mathrm{L}_{\mathrm{i}}} \cdot\left(\mathrm{f}_{\mathrm{i}} \cdot \mathrm{TOC}_{\mathrm{i}}\right) \cdot\left(\mathrm{Al}_{\mathrm{i}}\right)^{0.4} \cdot \exp \left[\frac{-89300}{8.314\left(\mathrm{~T}_{\mathrm{i}}+273\right)}\right] \\
& \mathrm{HGR}_{\mathrm{LAW}_{\mathrm{i}}}:=\mathrm{HGR}_{\mathrm{rad}_{\mathrm{i}}}+\mathrm{HGR}_{\text {therm }_{\mathrm{i}}}
\end{aligned}
$$


WSRC-TR-2005-00281, REVISION 0

SRNL-RPP-2005-00040, REVISION 0

\begin{tabular}{|c|c|c|c|c|}
\hline $\mathrm{G}_{0_{i}}=$ & $\mathrm{G}_{\mathrm{TOC}_{\mathrm{i}}}=$ & HGR $_{\mathrm{rad}_{\mathrm{i}}}=$ & HGR $_{\text {therm }_{i}}=$ & $\mathrm{HGR}_{\mathrm{LAW}_{\mathrm{i}}}=$ \\
\hline 0.048 & 0.64 & $3.077^{1} 10^{-3}$ & $4.755 \cdot 10^{-5}$ & $3.125 \cdot 10^{-3}$ \\
\hline 0.038 & 0.912 & $4.252 \cdot 10^{-3}$ & $4.079 \cdot 10^{-4}$ & $4.66 \cdot 10^{-3}$ \\
\hline 0.038 & 0 & $1.659 \cdot 10^{-4}$ & 0 & $1.659 \cdot 10^{-4}$ \\
\hline 0.038 & 0 & $1.522 \cdot 10^{-4}$ & 0 & $1.522 \cdot 10^{-4}$ \\
\hline
\end{tabular}

\section{Antifoam Agent Addition:}

Concentration of antifoam agent TOC introduced by weight percent is: $\mathrm{AFA}_{i}:=$

$$
\begin{array}{|l|}
\hline 0.2 \\
\hline 0 \\
\hline 1 \\
\hline 4 \\
\hline
\end{array}
$$

Immiscible Model: AFA Mixture is Second Phase

Assumed G-value for AFA mixture is $G_{\mathrm{imi}}\left(\mathrm{H}_{2}\right)=5 \mathrm{H}_{2}$ molecules per $100 \mathrm{eVG}$

The resulting G-value for the AFA addition is $G_{\mathrm{AFA}_{i}}:=\mathrm{G}_{\mathrm{imi}} \cdot \frac{\mathrm{AFA}_{\mathrm{i}}}{100}$

$$
\begin{aligned}
& \mathrm{G}_{\mathrm{AFA}_{\mathrm{i}}}= \\
& 0.01 \\
& \begin{array}{r}
0.01 \\
\hline 0 \\
\hline
\end{array} \\
& 0.05 \\
& 0.2
\end{aligned}
$$

The associated HGR is $\mathrm{HGR}_{-}$imiFA $_{\mathrm{i}}:=0.00895 \mathrm{H}_{\mathrm{i}} \cdot \mathrm{G}_{\mathrm{AFA}}$

$$
\begin{aligned}
& \text { HGR_imi. }_{\text {AFA }_{i}}= \\
& \begin{array}{|r|}
\hline 4.475 \cdot 10^{-5} \\
\hline 0.238 \cdot 10^{-4} \\
\hline 8.95 \cdot 10^{-4} \\
\hline
\end{array}
\end{aligned}
$$

NOTE: Set HGR_imi.AFA to zero for Miscible Model (next).

HGR_imiFA ${ }_{\mathrm{i}}:=0$ 
WSRC-TR-2005-00281, REVISION 0

SRNL-RPP-2005-00040, REVISION 0

\section{Summary of Results}

Miscible Model: AFA Mixture Dissolves in LAW

Assume that the AFA addition is miscible, and that it produces TOC with reactivity $f_{\mathrm{AFA}}=0.7$.

Then it creates additional hydrogen from these radiolysis and thermolysis terms:

Reactivity parameter for AFA TOC, $f_{\mathrm{AFA}}$, is $0.7: \mathrm{f}_{\mathrm{AFA}}:=$

\begin{tabular}{|l|}
\hline 0.7 \\
\hline 0 \\
\hline 0.7 \\
\hline 0.7 \\
\hline
\end{tabular}

$\mathrm{G}_{-} \mathrm{TOC}_{\mathrm{AFA}} \mathrm{i}=2.4910^{6} \cdot\left(\mathrm{f}_{\mathrm{AFA}_{\mathrm{i}}} \cdot \mathrm{AFA}_{\mathrm{i}}\right) \cdot \exp \left[\frac{-44300}{8.314\left(\mathrm{~T}_{\mathrm{i}}+273\right)}\right]$

HGR_rad $_{A F A_{i}}:=0.00895 f_{L_{i}} \cdot H_{i} \cdot G \_T O C_{A F A}$

$\mathrm{HGR}_{-}$therm $\mathrm{AFA}_{\mathrm{i}}:=2.7610^{9} \cdot \mathrm{f}_{\mathrm{L}_{\mathrm{i}}} \cdot\left(\mathrm{f}_{\mathrm{AFA}_{\mathrm{i}}} \cdot \mathrm{AFA}_{\mathrm{i}}\right) \cdot\left(\mathrm{Al}_{\mathrm{i}}\right)^{0.4} \cdot \exp \left[\frac{-89300}{8.314\left(\mathrm{~T}_{\mathrm{i}}+273\right)}\right]$

$\mathrm{HGR}_{\mathrm{AFA}_{\mathrm{i}}}:=\mathrm{HGR}_{-} \mathrm{rad}_{\mathrm{AFA}}+\mathrm{HGR}_{\mathrm{i}}$ therm $_{\mathrm{AFA}_{\mathrm{j}}}$

$\mathrm{G}_{\mathrm{AFA}_{\mathrm{i}}}=$ HGR_imi $_{\mathrm{AFA}}$

G_TOC $_{\text {AFA }_{i} \quad \text { HGR_rad }}$ AFA $_{i}$

HGR_therm AFA $_{i}$

$\mathrm{HGR}_{\mathrm{AFA}_{\mathrm{i}}}=$

\begin{tabular}{|r|}
\hline 0.01 \\
\hline 0 \\
\hline 0.05 \\
\hline 0.2 \\
\hline
\end{tabular}

0.147

\begin{tabular}{r|}
\hline 0 \\
\hline 0.735 \\
\hline 2.941 \\
\hline
\end{tabular}

\begin{tabular}{|r|}
\hline $6.58 \cdot 10^{-4}$ \\
\hline 0 \\
\hline $3.191 \cdot 10^{-3}$ \\
\hline 0.012 \\
\hline
\end{tabular}

\begin{tabular}{|r|}
\hline $1.093 \cdot 10^{-5}$ \\
\hline 0 \\
\hline $2.524 \cdot 10^{-4}$ \\
\hline $9.263 \cdot 10^{-4}$ \\
\hline
\end{tabular}

$6.69 \cdot 10^{-4}$

$3.444 \cdot 10^{-3}$

0.013

\section{Total Hydrogen Generation Rates:}

These are calculated for the Miscible Model:

$$
\begin{aligned}
& \text { HGR_AN107 }{ }_{\mathrm{AFA}}:=\mathrm{HGR}_{\mathrm{LAW}}+\mathrm{HGR}_{0} \mathrm{imi}_{\mathrm{AFA}_{0}}+\mathrm{HGR}_{\mathrm{AFA}_{0}} \\
& \text { HGR_B: }=\mathrm{HGR}_{\mathrm{LAW}_{1}}+\mathrm{HGR}_{-} \mathrm{imi}_{\mathrm{AFA}_{1}}+\mathrm{HGR}_{\mathrm{AFA}} \\
& \text { HGR_Gow }:=\mathrm{HGR}_{\mathrm{LAW}_{2}}+\mathrm{HGR}_{-} \mathrm{imiFA}_{2}+\mathrm{HGR}_{\mathrm{AFA}_{2}} \\
& \text { HGR_Gigh }:=\mathrm{HGR}_{\mathrm{LAW}_{3}}+\mathrm{HGR}_{-} \mathrm{imi}_{\mathrm{AFA}_{3}}+\mathrm{HGR}_{\mathrm{AFA}_{3}}
\end{aligned}
$$


HGRs, with units of g-mole $\mathrm{H}_{2}$ per day per $\mathrm{kg}$ waste:

Predicted:

HGR_AN107 $A F A=3.794 \times 10^{-3}$

HGR_B $=4.66 \times 10^{-3}$

HGR_Gow $=3.61 \times 10^{-3}$

HGR_Gigh $=1.279 \times 10^{-2}$
Measured:

$5.9 \times 10^{-4}$

$7.2 \times 10^{-4}$

$2.5 \times 10^{-4}$

$1.1 \times 10^{-3}$
Predicted/Measured:

$\frac{\text { HGR_AN107 AFA }}{5.9 \times 10^{-4}}=6.4$

$\frac{\text { HGR_B }}{7.2 \times 10^{-4}}=6$

$\frac{\text { HGR_Gow }}{2.5 \times 10^{-4}}=14$

$\frac{\text { HGR_G Gigh }}{1.1 \times 10^{-3}}=12$ 
WSRC-TR-2005-00281, REVISION 0

SRNL-RPP-2005-00040, REVISION 0

This page intentionally left blank. 